\title{
MEDICAL STATUS OF MARSHALLESE ACCIDENTALLY EXPOSED TO 1954 BRAVO FALLOUT RADIATION: JANUARY 1980 THROUGH DECEMBER 1982
}

William H. Adams, M.D., James A. Harper, M.D., Roger S. Rittmaster, M.D., Peter M. Heotis, and William A. Scott

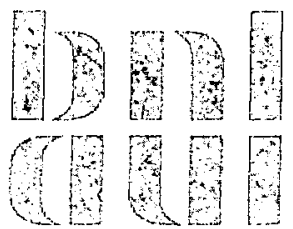

Statistical analyses were provided by:

R.C. Grimson, Ph.D.

Dept. of Community and Preventive Medicine Health Sciences Center

State University of New York at Stony Brook Stony Brook, New York 11794

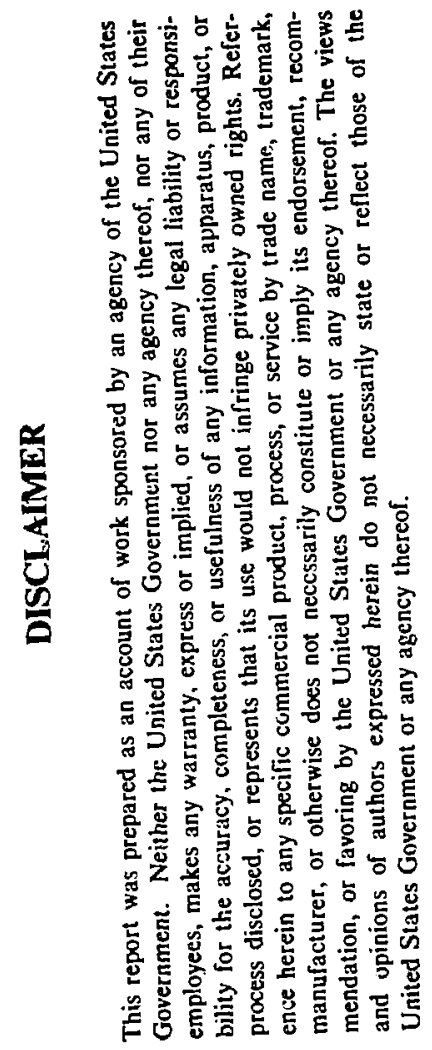

MEDICAL DEPARTMENT

BROOKHAVEN NATIONAL LABORATORY UPTON, LONG ISLAND, NEW YORK 11973 


\section{CONTENTS}

Page

List of Participants in Medical Surveys, 1980-1982 ............ v

Introduction $\ldots \ldots \ldots \ldots \ldots \ldots \ldots \ldots \ldots \ldots \ldots \ldots \ldots \ldots \ldots \ldots \ldots \ldots \ldots, 1$

Scope of the Medical Program $\ldots \ldots \ldots \ldots \ldots \ldots \ldots \ldots \ldots \ldots, 1$

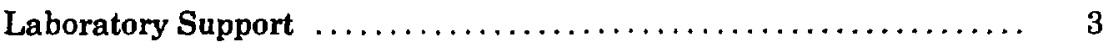

Medical Findings $\ldots \ldots \ldots \ldots \ldots \ldots \ldots \ldots \ldots \ldots \ldots \ldots \ldots \ldots \ldots \ldots \ldots \ldots$

Overall Mortality .................................. 3

Recent Mortality ................................ 3

Hematology . . . . . . . . . .

Markers of Possible Subclmical Neoplasia ................ 5

Immune Status $\ldots \ldots \ldots \ldots \ldots \ldots \ldots \ldots \ldots \ldots \ldots \ldots \ldots \ldots \ldots \ldots$

Nonthyroidal Neoplasms in Exposed Persons .............. 10

Thyroid Neoplasia $\ldots \ldots \ldots \ldots \ldots \ldots \ldots \ldots \ldots \ldots \ldots \ldots \ldots, 13$

Individual Laboratory Data $\ldots \ldots \ldots \ldots \ldots \ldots \ldots \ldots \ldots \ldots, 16$

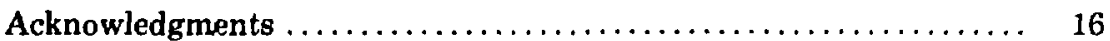

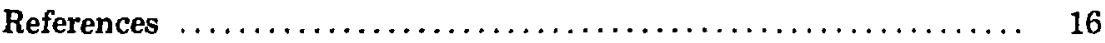

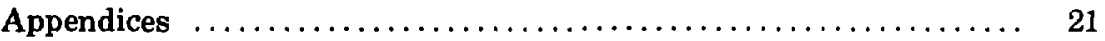




\section{Marshall Islands Survey Participants (1980 - 1982) \\ PROFESSIONAL STAFF}

Name, Participating Survey

Adams, William H., M.D.

(Mar. '8i, Oct. '81, Mar. '82, Oct. '82)

Arelong, Totha

(Oct. '82)

Barclay, Paula Jane, M.D.

(Mar. '82)

Becker, David, M.D.

(Mar. '81)

Biancaniello, Thomas, M.D.

(Oct. '81)

Brown, Edward, M.D.

(Mar. '82)

Catto, Brian, M.D.

(Mar. '81)

Cogswell, Frank B., Ph.D.

(Oct. '80)

Conard, Robert A., M.D.

(Oct. '80, Mar. '82)

Cook, Kevin, M.D.

(Mar. '81)

Cronkite, Eugene P., M.D.

(Oct. '80, Mar. '81)

Davenport, Deborah, M.D.

(Mar. '82)

\section{Affiliation}

Scientist, Brookhaven National

Laboratory, Upton, NY 11973

(Currently Principal Investigator, Marshall

Islands Study)

Nurse Practitioner

Armer Ishoda Memorial Hospital

Majuro, Marshall Islands 96960

Fellow in Rheumatology and Allergy

SUNY at Stony Brook

Stony Brcok, NY 11794

Professor of Medicine and Radiology

Director, Div, of Nuclear Medicine

The New York Hospital-Cornell

Medical Center, NY, NY 10021

Asst. Professor of Pediatrics

SUNY at Stony Brook

Stony Brook, NY 11794

Asst. Professor of Medicine

SUNY at Stony Brook

Stony Brook, NY 11794

Sr. Research Associate

Dept. of Pharmacology

Case Western Reserve University

Cleveland, OH 44106

Parasitologist

U.S. Public Health Hospital

210 State St.

New Orleans, LA 70118

Senior Scientist (Retired)

Brookhaven National Laboratory

Upton, NY 11973

(Formerly Principal Investigator, Marshall

Islands Study)

Family Practice Physician

Kwajalein Hospital

APO San Francisco 96555

Senior Scientist

Brookhaven National Laboratory

Upton, NY 11973

Senior Resident, Dept. of Obstetrics and Gynecology, SUNY at Stony Brook Stony Brook, NY 11794 


\section{Name, Participating Survey}

Dobyns, Brown, M.D.

(Oct. '80, Mar. '82)

Dungy, Claibourne, M.D.

(Oct. '82)

Ferguson, Fred S., D.D.S.

(Oct. '82)

Giorgio, Bernard, M.D.

(Oct. '80)

Harper, James A., M.D.

(Oct. '80, Oct. '81, Mar. '82, Oct. '82)

Hill, C. Stratton, Jr., M.D.

(May' 80 )

Iaman, John

(May '80, Oct. '80, Mar. '81, Mar. '82)

Ingalls, Jı:dith, M.D.

(Oct. '80)

Kabua, Jenuk

(May '80, Oct. '80, Mar. '81, Oct. '81,

Mar. '82, Oct. '82)

Ketchum, Dana, M.D.

(Oct. '81)

Kindermann, W. Reed, M.D.

(Mar. '81)

Krotoski, Andrew, D.D.S.

(Oct. '80)

\section{Alfiliation}

Professor of Surgery

Case Western Reserve, University School of Medicine, Clevelanà Metropolitan General Hospital

Cleveland, $\mathrm{OH} 44109$

Assoc. Prof., Dept. of Pediatrics

Medical Center

Univ. of California, Irvine

Orange, CA 92668

Associate Professor

Dept. of Children's Dentistry

School of Dental Medicine

SUNY at Stony Brcok

Stony Brook, NY 11794

Gynecology and Obstetrics

(Private Practice)

Pearl City, Hawaii 96782

Brookhaven National Laboratory

Family Practice Physician

Stationed at Kwajalein

APO San Francisco 96555

Assuciate Director (for Clinics)

M.D. Anderson Hospital and Tumor Institute

Texas Medical Center, Houston, TX

Practitioner

Armer Ishoda Memorial Hospital

Majuro, Marshall Is. 96960

Family Practice Physician

Maine Medical Center

Portland, ME 04,02

Nurse Practitioner

Brookhaven National Laboratory

Upton, NY 11973

(Stationed at Ebeye, Marshall Is.)

Pediatric Resident

Tulane Aff. Hospitals

New Orleans, LA 70118

Ophthalmology

Cherry Hill - Evesham Bldg.

Cherry Hill, NJ 08003

Private Practice

20445 Pacifica Drive

Cupertino, CA 95015 
PROFESSIONAL STAFF (Continued)

Name, Parlicipating Survey

Krotoski, Wojeiech A., M.D., Ph.D.

(Oct. '82)

Miller, Marilyn E., M.D.

(Mar. '81)

Morgan, Beverly C., M.D.

(Oct. '82)

Mueller, Linda G., M.I.

(May '80, Mar. '81)

Nicoloff, Ruth L., M.D.

(Mar. '82)

Paglia, Donald E., M.D.

(Mar. '81)

Palmer, Lucy, M.D.

(Mar. '82)

Partin, John C., M.D.

(Oct. '81)

Pratt, Hugh S., M.D.

(May '80)

Randell, David, M.D.

(Mar. '81)

Rittmaster, Roger, M.D.

(May '80, Oct. '80, Mar. '81)

\author{
Affiliation \\ Parasitology/Tropical Medicine \\ U.S. Publir Health Hospital \\ New Orleans, LA 70118 \\ Currently: Laboratory Research Branch \\ National Hansen's Disease Center \\ Carville, LA 70721
}

Scientist

Brookhaven National Laboratory

Upton, NY 11973

Prof./Chairperson, Dept. Pediatrics

Medical Center

Univ. of California, Irvine

Orange, CA 92668

Family Practice Physician

Brookhaven Memorial Hospital

East Patchogue, NY 11772

Gynecology and Obstetrics

Southern California Permanente

Medical Center

Los Angeles, CA 90027

Prof., Div. of Surgical Pathology

Univ. of California, L.A.

Los Angeles, CA 90024

Pulmonary Fellow

Yale-New Haven Hospital

New Haven, CT 06520

Prof./Chairman, Dept. of Pediatrics

School of Medicine

SUNY at Stony Brook

Stony Brook, NY 11794

Scientist

Brookhaven National Laboratory

Upton, NY 11973

(Formerly Principal Investigator,

Marshall Islands Study)

Ophthalmology (Private Practice)

Kaneohe, Hawaii 96744

Brookhaven National Laboratory

Physician stationed at Kwajalein

('80-'81), APO San Francisco 96555

Currently: National Institutes of Health

Bethesda, MD 20014 


\section{Name, Participating Survey}

Schlissel, Edward, D.D.S.

(Oct. '81)

Smith, Eva Marie, M.D.

(Oct. '80)

Taguchi, Douglas, M.D.

(Mar. '81)

Thomas, Carol, R.N.

(May '80)

Thomas, Ronald W., M.D.

(May '80)

Yosidizama, Sulikau

(Oct. '81)

Zij.umerman, Steven H., M.D.

(Mar. '81)

\author{
Affiliation \\ Assoc. Prof. Restorative Dentistry \\ Asst. Dean, Clinical Affairs \\ School of Dental Medicine \\ SUNY at Stony Brook \\ Stony Brook, NY 11794 \\ Family Practice Physician \\ Brookhaven Memorial Hospital \\ East Patchogue, NY 11772 \\ Gynecology and Obstetrics \\ Los Angeles, CA 90017 \\ Southern Missionary College \\ Divison of Nursing \\ Collegedale, TN 37315 \\ Bradley Memorial Hospital \\ Chambliss Ave. \\ Cleveland, TN 37311 \\ Nurse Practitioner \\ Ebeye Hospital \\ Ebeye, Marshall Is. 96970 \\ Internal Medicine \\ Maine Medical Center \\ Portland, ME 04102
}

\section{TECHNICAL SPECIALISTS}

\section{Name, Participating Survey}

Adams, Diana

(Oct. '81, Mar. '82, Oct. '82)

Bettrie, Kalman

(Mar. '82)

Bien, Peter

(Mar. '81)

Brown, Robert A.

(May '80, Mar. '81)

deBrum, Reynold

(Oct. '80, Mar. '81, Oct. '81,

Mar. '82, Oct. '82)

Elanjo, Laijo

(May '80, Oct. '80, Mar.'81)

Emos, Helmer

(May '80, Oct. '80, Oct. '81, Mar. '82)

\author{
Affiliation \\ Medical Department \\ Brookhaven National Laboratory \\ Upton, NY 11973 \\ Ebeye Hospital \\ Ebeye, Marshall Is. 96970 \\ Armer Ishoda Memorial Hospital \\ Majuro, Marshall Is. 96960 \\ Medical Department \\ Brookhaven National Laboratory \\ Upton, NY 11973 \\ U.S. Department of Energy \\ Majuro, Marshall Is. 96960 \\ Armer Ishoda Memorial Hospital \\ Majuro, Marshall Is. 96960 \\ Medical Department \\ Brookhaven National Laboratory \\ Upton, NY 11973 \\ (Stationed at Ebeye, Marshall Is.)
}


TECHNICAL SPECIALISTS (Continued)

\section{Name, Participating Survey}

Ferguson, Robert

(Oct. '82)

Gideon, Kalman

(May '80, Mar. '81)

Heotis, Peter

(May '80, Oct. '80, Mar. '81,

Oct. '81, Mar. '82, Oct. '82)

Hicks, Elizabeth

(Mar. '82)

Lang, Jokna

(Mar. '81)

Lehman, William P.

(Mar. '81)

Macisso, David

(Oct. '80)

Philip, Reno

(May '80, Mar. '81)

Reidel, Agnes

(Oct. '80, Mar. '81, Oct. '81, Mar. '82)

Saul, Joe

(Oct. '82)

Scott, William

(May '80, Oct. '80, Mar. ' 81 ,

Oct. '81, Mar. '82, Oct. '82)

Shoniber, Sebio

(May '80, Oct. '80, Mar. '81

Oct. '81, Mar. '82, Oct. '82)

Weldon, Thomas

(May '80)

\section{Alfiliation}

Medical Department

Brookhaven National Laboratory

Upton, NY 11973

Armer Ishoda Memorial Hospital

Majuro, Marshall Is. 96960

Medical Department

Brookhaven National Laboratory

Upton, NY 11973

Medical Department

Brookhaven National Laboratory Upton, NY 11973

Ebeye Hospital

Ebeye, Marshall Is. 96970

Medical Department

Brookhaven National Laboratory

Upton, NY 11973

Maine Medical Center

Portland, ME 0,4102

Ebeye Hospital

Ebeye, Marshall Is. 96970

Ebeye Hospital

Ebeye, Marshall Is. 96970

Arrrer Ishoda Memorial Hospital

Majuro, Marshall Is. 96960

Medical Department

Brookhaven National Laboratory

Upton, NY 11973

Armer Ishoda Memorial Hospital

Majuro, Marshall Is. 96960

Medical Department

Brookhaven National Laboratory

Upton, NY 11973 


\section{Introduction}

This report updates, for 1980 through 1982 , the results of continuing medical surveillance of a Marshallese population accidentally exposed to radioactive fallout in March 1954. It is the sixty-fifth in a series of publications from the Medical Department, Brookhaven National Laboratory, concerning the effects of that exposure, all publications beinf, listed in the Reference section beginning on page 16. Many of these publications include details of the acute effects suffered by the Marshallese and the radiologic assessments at the time of, and subsequent to, the fallout, with the most recent summary being Dr. Robert Conard's 26-year review. ${ }^{1} \mathrm{~A}$ recounting of those events is thercfore not included in this report.

The originally exposed Marshallese population comprised 64 persons on Rongelap Atoll who each received, on the average, an estimated 190 rads of absorbed external gamma radiation, 18 on Ailingnae Atoll who received 110 rads, and 159 on Utirik who received 11 rads (see Appendix I for the derivation of these new dose estimates). There were, in addition, 3 persons in utero on Rongelap, 1 person in utero on Ailingnae, and $8^{*}$ persons in utero on Utirik who are considered exposed. Under the Brookhaven National Laboratory program, the recipients of primary medical care include exposed and comparison populations as well as a rather large number of additional beneficiaries who are seen on a humanitarian basis of practical need and resource availability. In recent years, about 1400 people have been seen annually. This report, however, deals with four clearly defined groups: the remaining individuals who were exposed to radioactive fallout on Rongelap, Ailingnae, and Utirik in 1954 (including those in utero), and a comparison population of individuals from Rongelap who were unexposed. The number of persons now in each exposure category are $51,12,116$, and 137 , respectively.

The unexposed comparison group, which was individually matched by age and sex against the combined Rongelap and Ailingnae groups in $1957,{ }^{2}$ has varied in composition over the years as some individuals have voluntarily withdrawn or been lost to followup and others

\footnotetext{
*This number includes two previously unidentified persons confirmed in 1982 as being exposed in utero.
}

have been added. There has been, in addition, the expected natural mortality. Despite these factors, chi-square values based on contingency table analysis currently reveal no statistically significant differences between the age, sex, and age-sex distributions of the combined Rongelap-Ailingnae group and the comparison population. Statistical analysis also shows an equivalent but fortuitous similarity between the Utirik and comparison groups.

\section{Scope of the Medical Program}

Participation in the Brookhaven National Laboratory medical program is voluntary for both exposed and unexposed Marshallese. The program itself, however, which Brookhaven National Laboratory is under contract to the Department of Energy to carry out, is currently mandated by Public Law 95-134. Its expressed purpose is to provide "care and treatment" of radiation-related disease in the exposed population. No such etiologic distinction is made in actual medical practice, however. There is, of course, particular attention paid to thyroid neoplasia, as over the years that is one disease category clearly associated with the high radiation exposure of some of the Marshallese. In addition. surveillance for nossibly radiationrelated disease is undertaken because the exposed population must be considered at increased risk for such disorders. For example, when a prolactinoma was diagnosed in an exposed woman in 1981, sera from virtually all exposed persons were tested for the presence of hyperprolactinemia (see below). This extra dimension in medical surveillance does not detract from primary care coverage. It is through the provision of comprehensive medical coverage that unpredicted effects of radiation exposure can be effectively disclosed.

Thus the medical program continues to address a wide variety of health matters. Updating of children's immunizations is a regular part of the medical team visits to Rongelap and Utirik. This is done in conjunction with a public health nurse from the Republic of the Marshall Islands Health Services. An intestinal helminth control program begun in 1978 was continued through 1982. Clinical care of diabetic patients now includes routine determi. nations of hemoglobin $A_{1 c}$ levels. An attempt at 
diabetes education, which has included distribution of a brochure on diabetic care that was translated into Marshallese for patients, is an ongoing process, as diabetes is a serious medical problem in the Republic of the Marshall Islands. A survey for folic acid and vitamin $B_{12}$ deficiencies has been completed. Dental care has been redirected toward preventive dentistry; repairs and restorations are now the main thrust rather than extractions which can be managed by local personnel. A major effort has been directed at the inclusion of a wide variety of specialists and subspecialists as participants on the medical teams. Participants have been chosen from excellent medical centers throughout the United States. These physicians not only perform the required routine physical examinations; they greatly increase the diagnostic and therapeutic capabilities of the team in handling unusual or difficult problems. Their services are also offered to the Republic of the Marshall Islands Health Services as time permits. The specialties and subspecialties utilized in 1980-1982 are listed below:

Dentistry (adult and pediatric)
Endocrinology
Family Practice
Hematology
Internal Medicine (including Fellows
in Rheumatology and Pulmonary
Medicine)
Nuclear Medicine
Obstetrics and Gynecology
Oncology
Ophthalmology
Pediatric Cardiology
Pediatrics
Surgery
Tropical Medicine and Parasitology

Tropical Medicine and Parasitology
For the 3-year period covered by this report, medical surveys have been conducted semiannually. The "Spring Survey" offers complete medical examinations to all exposed individuals, the comparison population, and all persons 15 years of age or older residing on Rongelap and Utirik Atolls. In addition, a daily sick call is available to anyone in the younger age group. At the population centers of Ebeye and Majuro, complete examinations are available to all exposed persons and to members of the comparison group. The "Fall Survey" permits examinations of persons missed in the spring and followup of medical problems. It also enables and facilitates pediatric/dental coverage. Complete examinations are offered to all individuals under 15 years of age residing on Rongelap and Utirik Atolls, and a sick call service is available daily to all others. At Ebeye and Majuro, examinations are offered to children of the exposed and comparison populations. Followup care for people with chronic medical problems such as diabetes and hypertension is a focus of both major surveys as well as the periodic visits of our physician-in-residence (see below).

Persons with identified problems clearly unrelated to radiation exposure and beyond the capabilities of the medical team are referred to the Republic of the Marshall Islands Health Services. Radiation-related illnesses, possibly radiation-related illnesses, and medical evaluations which could conceivably lead to the diagnosis of a radiation-related or possibly radiation-related illness are handled through medical channels established with the help of the Department of Energy Pacific Area Support Office in Honolulu.

In the early 1970 s, some Bikini families resettled Bikini Island. The peak population during this period was about 140 . Because of the remoteness of Bikini and the apprehensions of the settlers, the medical team was authorized to extend its Rongelap/Utirik surveys to provide sick call visits to Bikini. These settlers were again relocated to Kili and Ejit (Majuro) in 1978. At the request of the Department of the Interior, following this relocation, these Bikinians have been seen twice a year during the Majuro visits.

An attempt to provide medical coverage between the semiannual medical team visits has been continued. A Brookhaven National Laboratory physician is stationed on Kwajalein, and office hours and laboratory services are maintained on Ebeye, to which the physician commutes daily. In addition to providing primary medical care for persons holding a Brookhaven National Laboratory identification card on Ebeye, the physician undertakes periodic visits to Rongelap and Utirik. Such visits must be performed within limits set by available transportation to these remote atolls. A Brookhaven National Laboratory nurse and/or technician, both Marshallese, accompany the physician. A Brookhaven National Laboratory technician 
/administrator stationed at Kwajalein in 1978 returned to the United States in 1981. He was replaced by the Marshallese laboratory technician who had completed a clinical laboratory training course in.Honolulu under the auspices of Brookhaven National Laboratory. Other Marshallese medical and paramedical personnel who are included on the semiannual medical trips are provided by the Republic of the Marshall Islands. They are listed among the team participants on pages v-ix.

In 1981-82 five reports on matters pertinent to public health were submitted to the Minister of Health, Republic of the Marshall Islands. These reports were based on data collected during the course of the semiannual medical trips. The topics included the prevalence of anemia, toxoplasmosis, hyperuricemia, yaws (an analysis of serologic tests), and clinical findings of a pediatric trip. This is an ongoing project. Sharing of such data obtained from the populations we serve may benefit the Marshallese people as a whole.

\section{Laboratory Support}

Most medical activities and all laboratory services of the Brookhaven National Labóratory medical surveys are conducted aboard a chartered U.S. Oceanography vessel, Liktanur II. Exceptions include the examinations performed in Brookhaven National Laboratory facilities on Ebeye and pediatric examinations at Rongelap and Utirik which, for reasons of the children's safety, are carried out in dispensaries on. shore.

Laboratory support during the medical trips is provided by four technicians. Routine fiveparameter blood counts are performed on a J.T. Baker 500A electronic particle counter and sizer. Leukocyte differentials and phase contrast platelet counts are done concurrently. A battery of clinical tests (including serum creatinine, glucose, amylase, uric acid, and liver function tests) are carried out on a Beckman spectrophotometer with commercially available reagent kits. Serum sodium and potassium measurements are made on a Beckman Instruments Electrolyte 2 system. Urinalysis (dipstick and microscopic), stool examinations (for occult blood and parasites), and bacteriologic cultures (aerobic and anaerobic) with antibiotic sensitivity testing are available. Hemoglobin $A_{1 c}$ determinations, glucose-6-phosphate dehydrogenase testing, and erythrocyte sedimentation rates are also provided. Serum is routinely separated and frozen for thyroid function tests and other studies which must be sent to commercial or university laboratories. Fingerstick techniques are used on young children whenever possible. An x-ray machine is available for most commonly required roentgenograms. Electrocardiograms are also available.

Referral laboratories for studies mentioned in this report include: BioScience Laboratories in Honolulu (special chemistries, serologic tests), Pathologists Laboratories, Inc. (Papanicolaou smear readings), the Endocrinology Laboratory at Brigham and Women's Hospital, Boston (thyroid function tests and prolactin assays), Protozoal Diseases Branch, Centers for Disease Control, Atlanta (toxoplasma serologies), Division of Endocrinology and Metabolism, Reese Hospital and Medical Center, Chicago (thyroglobulin levels), Hematology Laboratory at the University of California, San Francisco (erythropoietin assays), Parasitology Laboratory of the National Hansen's Disease Center, Carville (ova and parasite identifications), and the Hematology Laboratory, University of Louisville School of Medicine (folic acid and vitamin $\mathrm{B}_{12}$ assays).

\section{Medical Findings \\ OVERALL MORTAL!TY}

The age- and sex-matched comparison population of 86 Marshallese ${ }^{2}$ selected in 1957 has been used in the construction of survival curves. Although 38 of these persons are no longer seen for annual medical examinations (26 are deceased), their status has been made available to the medical team through personal acquaintances of the individuals. Figure 1 shows the survival of the exposed and unexposed populations through 1982. Note that data collection on the comparison group began in 1957 rather than 1954. Use of the tests of Mantel ${ }^{3}$ and Breslow ${ }^{4}$ revealed no statistically significant difference between the survival curves of each of the exposed groups and the comparison group.

\section{RECENT MORTALITY}

The following 10 deaths have been recorded since the 26-year report ${ }^{1}$ : 


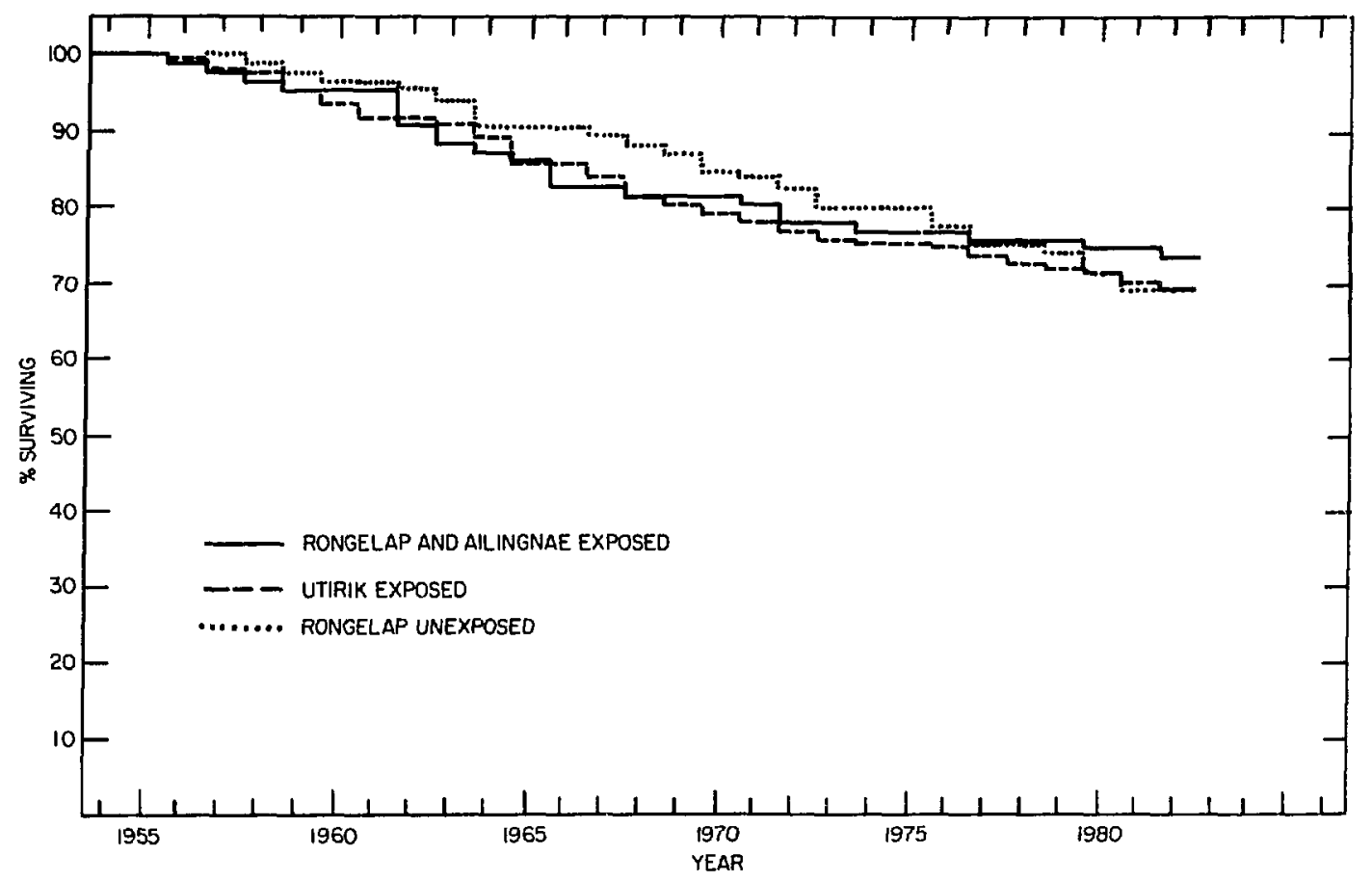

Figure 1. Percent survivors of the different exposure groups since 1954.

The curves are based on the total original populations, including those in utero.

\section{Rongelap}

NONE

\section{Allingnae}

Subject No. 51. This 51-year-old woman had severe chronic obstructive pulmonary disease with marked emphysematous changes on chest $x$ ray and evidence of cor pulmonale on her electrocardiogram. Chronic bronchitis and emphysema had been persistent at least since 1974. She expired at Majuro Hospital.

\section{Utirik}

SUBJErT No. 2241. This 56-year-old woman died at Straub Clinic and Hospital (Honolulu) with septicemia resulting from diabetes (known for at least 6 years) and a recent above-the-knee amputation stump that had become infected after surgery at Ebeye Hospital.

SUBJECT No. 2161. This 56-year-old woman died on Ailinglapalap Atoll after a two-month illness characterized by abdominal pain and jaundice. The cause of the illness is unknown as no physician was in attendance. Other medical problems had included post-polio paralysis since childhood and bilateral congenitally dislocated hips.

SubJECT No. 2120. Insulin-requiring diabetes and severe neuropathy were the major problems of this 70-year-old man when last examined in 1982. He was being followed at Majuro Hospital where he died later that year.

\section{Comparison}

SubJECT No. 982.. This 61-year-old lady had a history of moderate hypertension under treatment for at least 15 years: In 1980 she had a paralytic stroke complicated by pneumonia and was referred to the Ebeye Hospital. She died in April 1981.

SubJect No. 849. This 62-year-old man had diabetes treated with insulin. Severe peripheral vascular disease had led to bilateral leg amputations in 1972 and 1977. No other significant problems were detected on his last examination in 1980. He died in 1981. 
SUBJECT No. 889. This 55-year-old woman had ductal carcinoma of the breast with positive axillary nodes diagnosed in 1980 . She was treated at Straub Clinic and Hospital and returned to Ebeye to be placed on chemotherapy, but expired late in 1980 .

SubJECT No. 1554. Diabetes and senility were the clinical problems of this 62-year-old woman who died in 1981 on Ebeye.

SubJect No. 1571. Neurologic abnormalities detected on the 1982 examination led to the diagnosis of a spinal cord tumor (astrocytoma) in this 28-year-old woman. She died at Tripler Army Hospital following surgery for the tumor in 1982.

Subject No. 945. This 57-year-old woman had severe pulmonary disease $\left(\mathrm{FEV}_{1}=0.5\right)$ and a history of cough and dyspnea for many years. She died in 1982 after being admitted to Ebeye Hospital with increasing cough and chest pain. Tuberculosis had not been confirmed in earlier evaluations, and the cause of the lung disease was not ascertained.

\section{HEMATOLOGY}

No hematologic malignancies were diagnosed in 1980-1982. Mean neutrophil counts (Figure 2a) in the Rongelap and Ailingnae groups remain, as in most years, slightly lower than control values. Lymphocyte counts (Figure 2b) are low only in the small Ailingnae group, although mean Rongelap values were below control levels during the early years of surveillance. Platelet counts (Figure $2 \mathrm{c}$ and $\mathrm{d}$ ) are currently near control levels, although in retrospect one can argue that it may have taken about 20 years for this to occur in the Rongelap group. Hematocrit values have always been within a few percent of control levels and are not shown.

There have been few statistically significant differences in biood counts between exposed and unexposed groups on a year-to-year basis. The relative constancy of the differences over many years, however, raises the possibility of long-term constraints on hematopoiesis in the Rongelap and Ailingnae groups.

The following table is an analysis of group differences in the blood cell counts of Figure 2. The entries are $p$ values for tests of trend of blood cell counts over time, ${ }^{5}$ the counts of the exposed groups being less than the comparison group in all instances.

\begin{tabular}{lcc}
\hline & $\begin{array}{c}\text { Rongelap vs } \\
\text { Comparison }\end{array}$ & $\begin{array}{c}\text { Ailingnae vs } \\
\text { Comparison }\end{array}$ \\
\hline Neutrophils & 0.04 & 0.04 \\
Lymphocytes & NS & 0.004 \\
Platelets (females) & 0.04 & NS \\
Platelets (males) & 0.04 & NS \\
\hline
\end{tabular}

NS $=$ not significant

The nonparametric test used in this analysis is une of low sensitivity, and a morc detailed analysis is in preparation. In particular, the effects of mortality on trend will be investigated.

Although there could have been inherently different counts among the groups irrespective of radiation exposure, the significance of the latter is suggested by the observation that three cell lines reflect the same trend. The possibility that there may be such a long-term depression of hematopoietic elements stands in contrast to data from other sources. Occasional differences in blood counts have been noted between radiation-exposed and control populations in Japan, but the differences "were small and too irregular with respect to age, sex, and time of exposure to be attributed conclusively to radiation exposure." Quantitative recovery of hematopoietic tissue from acute radiation injury is often complete within $2-3$ months. ${ }^{7}$ There is no reason to infer clinical significance from the present findings; the variations, on both a group and an individual basis, are minor, and there is no evidence so far of increased susceptibility to infection in exposed persons.

\section{MARKERS OF POSSIBLE SUBCLINICAL NEOPLASIA}

A variety of tests have been performed as a part of surveillance efforts to detect neoplastic or paraneoplastic processes which might remain subclinical for extended periods. In 1981, 400cell leukocyte differentials were done to look for changes in low frequency cells, particularly monocytes and basophils (Table 1). Macrocytosis and polycythemia are routinely evaluated when clinically indicated, and grouped values 

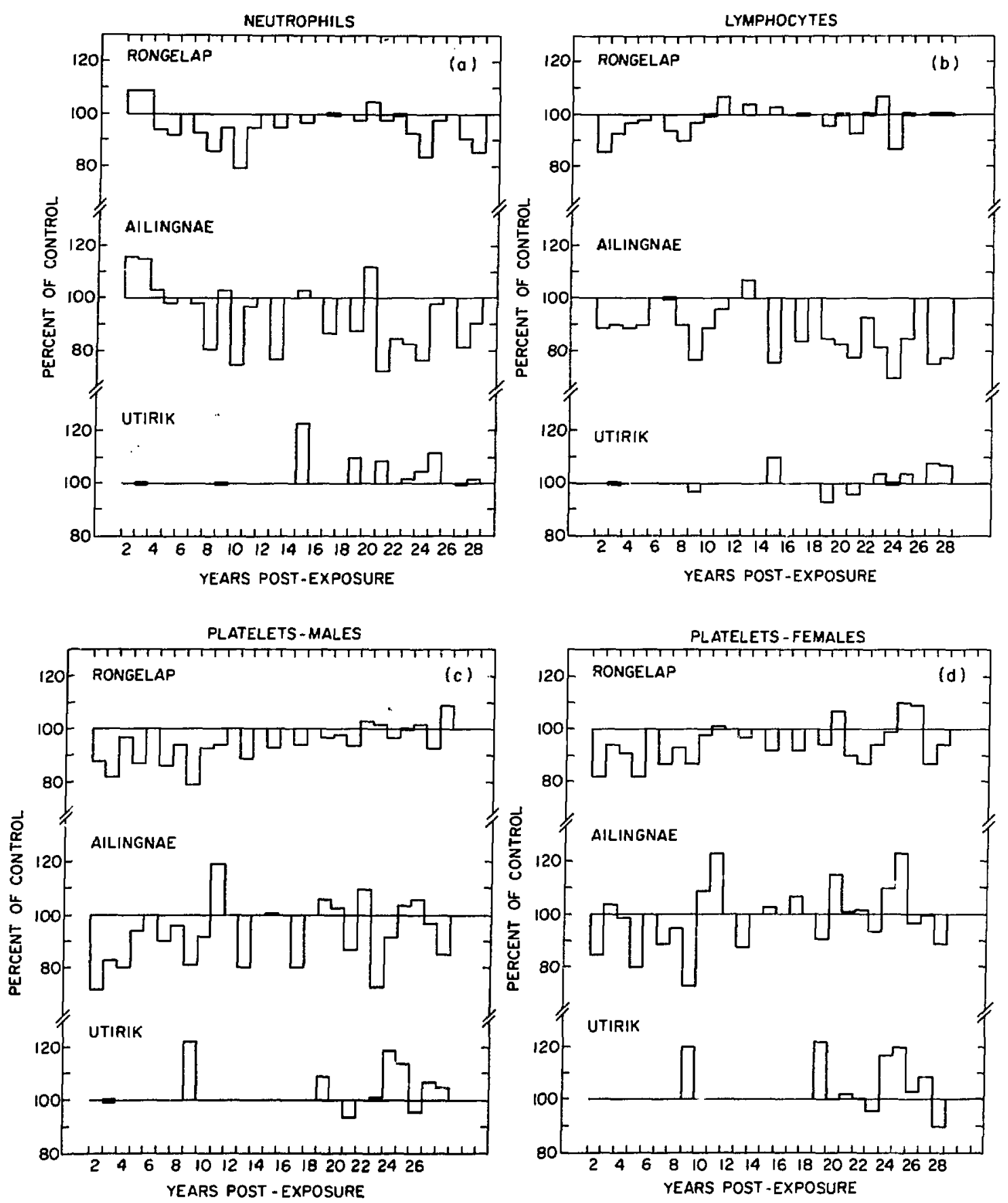

Figure 2. Mean blood cell counts of the different exposure groups (age 5 years or more) expressed as percent of control, beginning two years after exposure. Values for both sexes are grouped for neutrophils and lymphocytes. Detailed annual observations on Utirik blood cell counts were not begun until 1973. Leukocyte differentials or platelet counts were not obtained for six and fi $:$ annual examinations, respectively, although for graphing purposes the $100 \%$ line has not been broken at those years. 
Table 1

Grouped values ( \pm SD) of hematologic data obtained from persons who had 400-cell leukocyte differential counts in 1981 . Using analysis of variance and t-tests, no significant differences were found among the exposure groups or between exposed groups and the comparison population.

\begin{tabular}{|c|c|c|c|c|}
\hline $\begin{array}{l}\text { Exposure } \\
\text { Group (n) }\end{array}$ & Monocytes $/ \mu \mathrm{l}$ & Basophils/ $\mu$ l & $\begin{array}{c}\text { Mean } \\
\text { Corpuscular } \\
\text { Volume (f) }\end{array}$ & $\begin{array}{l}\text { Hemoglobin } \\
(\mathrm{g} / \mathrm{dl})\end{array}$ \\
\hline Rongelap (46) & $354 \pm 139$ & $9.3 \pm 21$ & $91.7 \pm 5$ & $14.2 \pm 1.6$ \\
\hline Ailingnae (13) & $338 \pm 166$ & $7.7 \pm 17$ & $90.4 \pm 5$ & $13.9 \pm 1.2$ \\
\hline Utirik (108) & $375 \pm 167$ & $11.6 \pm 20$ & $88.9 \pm 5$ & $14.2 \pm 1.7$ \\
\hline Comparison (103) & $386 \pm 177$ & $10.8 \pm 21$ & $90.0 \pm 5$ & $14.2 \pm 1.4$ \\
\hline
\end{tabular}

for mean corpuscular volume and hemoglobin level, also from 1981, are shown in the same table. In 1982 the following special tests were performed: serum erythropoietin assays were obtained on many individuals, including all those with elevated or high-normal hemoglobin levels, using a sensitive radioimmunoassay, ${ }^{8}$ and serum calcium and serum protein levels, as well as serum protein electrophoresis, were done on all exposed individuals. The results are discussed below.

Monocytes. The normal monocyte concentration in peripheral blood is approxi:nately $300 / \mu$ l with an upper limit of normal of about $800 / \mu 1 .{ }^{9}$ Values above this could be 1 ) occasionally normal; 2) the result of statistical variability inherent in a differential count; 3 ) due to a variety of infectious and granulomatous diseases; and 4) an accompaniment of a malignant process, including preleukemia. Mean values were similar in all exposure groups. Using analysis of variance and t-tests, significant differences were not found among the four exposure groups or between exposed groups and the comparison population. Four persons from Utirik and two from the comparison population had counts exceeding $800 / \mu$ l. All but one (a person from Utirik who has not presented for reexamination) were normal when retested.

Basophils. These cells normally number less than $200 / \mu \mathrm{l}$, with a mean of $40 / \mu \mathrm{l}$. Basophilia is often seen in the various myeloproliferative syndromes. There were no statistically significant differences among the exposure groups. The highest value recorded, $120 / \mu \mathrm{l}$, was in the unexposed population.
Mean Corpuscular Volume (MCV). An increase in the size of erythrocytes is most often due to alcoholism or a deficiency of folic acid or vitamin $B_{12}$. It can also be seen with aplastic anemia, sideroblastic anemia, preleukemia, and occasionally with solid tumors. There were no statistically significant differences in MCV among the exposure groups. The upper limit of normal for the MCV is about $100 \mathrm{fl}$. In 1981 one person from Rongelap, a 7.0-year-old woman, exceeded this (MCV of $102 \mathrm{f}$ ). Her serum $B_{12}$ level was found to be low $(108 \mathrm{pg} / \mathrm{ml})$, although intrinsic factor antibodies were absent. She was started on parenteral vitamin $B_{12}$.

Hemoglobin. There were no statistically significant differences in mean hemoglobin level among the exposure groups. The upper limits of normal in Marshallese have been found to be approximately $17.7 \mathrm{~g} / \mathrm{dl}$ for men and $15.7 \mathrm{~g} / \mathrm{dI}$ for women. These are identical to values found in a normal U.S. population. ${ }^{9}$ Poiycythemia is seen most often in heavy smokers, but it can also occur with the myeloproliferative syndromes and certain solid tumors, particularly those of renal or hepatic origin. Polycythemia vera, a myeloproliferative disorder, characteristically has a depressed level of serum erythropoietin. No low levels were found in any person tested. High erythropoietin levels are characteristic of the polycythemias due to solid tumors. No high levels were found in any nonanemic individual.

Serum Calcium. Hypercalcemia (serum calcium $>10.5 \mathrm{mg} / \mathrm{dl}$ ) can be caused by, among other things, parathyroid adenomas and many malignant diseases, usually metastatic tumors. 
There is increasing evidence of an association of parathyroid adenomas and hyperparathyroidism with radiation exposure to the head and neck regions. ${ }^{10}$ Two persons from Utirik and one of the comparison population had mildly elevated serum calcium levels of 10.9-11.2 $\mathrm{mg} / \mathrm{dl}$. These are to be rechecked when the individuals appear for reexamination.

There were no low serum albumin levels which could have resulted in the masking of hypercalcemia.

Serum Profein Electrophoresis. Monoclonal increases in serum globulins can occasionally be berign, but they are also seen in association with myeloma, lymphoma, and solid tumors. No monoclonal spikes were found on serum protein electrophoresis. A decrease in gamma globulin is a frequent finding in the lymphoproliferative disorders. The normal range for gamma globulin is from 0.50 to $1.40 \mathrm{~g} / \mathrm{dl}$. The lowest value found in the Marshallese was $1.20 \mathrm{~g} / \mathrm{dl}$. There were no significant differences in mean gamma globulin values among the exposure groups (Table 2).

\section{IMMUNE STATUS}

In 1957 the first of several tests for evaluating the immune function of exposed Marshallese was performed. ${ }^{2}$ The serologic responses to primary and secondary challenges of tetanus toxoid were found not to be significantly different between exposed and unexposed persons, although the range of titers was great, the number of persons tested was small, and the primary response was somewhat lower in the exposed. In 1959 complement fixation tests for a battery of viral and rickettsial diseases (including influenza, mumps, and adenovirus) were performed. The Rongelap group had lower mean titers than the comparison group for most of the complement-fixing antibodies tested. ${ }^{11}$ No significant differences were noted in serum protein electrophoretic studies in 1957. In 1969, however, exposed persons had a mean gamma globulin level $18.3 \%$ below that of the comparison group $(p=0.01) .^{12}$ In 1974 this difference was not noted. ${ }^{13}$ The gamma globulin levels measured in 1982, shown in Table 2, again reveal no statistically significant differences among exposure groups. Also included in Table 2 are the mean 1982 lymphocyte counts; the Ailingnae values are, by t-test analysis, significantly lower than that of the comparison group $(\mathrm{p}<0.05)$.

Ophthalmologic examinations in 1981 revealed the presence in several individuals of lesions compatible with ocular toyoplasmosis. Toxoplasma gondii is an intracellular protozoan which is most commonly disseminated among humans via cat feces or inadequately cooked pork. It elicits both humoral and cellular imınune responses, and medical complications are more commonly severe in those individuals with a suppressed immune mechanism. ${ }^{14} \mathrm{Be}-$ cause of the potential risk of toxoplasmosis to exposed persons, a serologic survey for toxoplasma antibodies was performed on $517 \mathrm{Mar}$ shallese sera collected at the time of the annual examinations in 1982.

Table 2

Grouped values ( \pm SD) for serum gamma globulin and lymphocyte count, 1982. No statistically significant difference between exposed and unexposed groups was found for gamma globulìn, but lymphocytes were lower $(\mathrm{p}<0.05)$ for the Ailingnae group (t-test).

\begin{tabular}{|c|c|c|c|c|}
\hline & Ronegelap & Ailingnae & Utirik & Comparison \\
\hline $\begin{array}{l}\text { Gamma Globulin } \\
\mathrm{g} / \mathrm{dl^{* }}(\mathrm{n})\end{array}$ & $\begin{array}{c}1.91 \pm 0.41 \\
(46)\end{array}$ & $\begin{array}{c}1.81 \pm 0.24 \\
(9)\end{array}$ & $\begin{array}{c}1.98 \pm 0.45 \\
(93)\end{array}$ & $\begin{array}{l}1.96^{-\lrcorner}-0.48 \\
(92)\end{array}$ \\
\hline $\begin{array}{l}\text { Lymphocytes/ } \\
\mu l(\mathrm{n})\end{array}$ & $\begin{array}{l}2778 \pm 791 \\
(47)\end{array}$ & $\begin{array}{c}1983 \pm 653 \\
(10)\end{array}$ & $\begin{array}{l}2865 \pm 904 \\
(93)\end{array}$ & $\begin{array}{c}2732 \pm 793 \\
(99)\end{array}$ \\
\hline
\end{tabular}

*Normal range at Brookhaven National Laboratory -0.50 to $1.40 \mathrm{~g} / \mathrm{dl}$. 
Almost all individuals tested were over 15 years of age. Fluorescent immunoassays were performed by the Parasitic Diseases Branch of the Centers for Disease Control, Atlanta, Georgia. The overall prevalence of positive titers was $93.6 \%$, a finding to be expected on the basis of investigations by others in tropical regions, including Oceania. ${ }^{15,16}$ A greater number of persons with insignificant titers $(<4)$ was found in the Rongelap and Ailingnae groups (Table 3a). Furthermore, the mean log titer (MLT) of the combined Rongelap and Ailingnae groups was significantly lower than those of the Utirik and comparison groups $(p<0.05)$. The MLTs of the four groups were similar, however, when titers $<4$ were excluded, suggesting that if infection did occur there was little, if any, difference in ability to mount an antibody response. Table $3 b$ shows that individuals living on Rongelap had the lowest MLTs whether or not exposed persons from Rongelap and Ailingnae were included, although the difference is not statistically significant. It is possible, therefore, that the lower mean toxoplasma antibody titer of the Rongelap-Ailingnae exposure group was due to a decreased opportunity for exposure to the

Table 3

Serum toxoplasma titers and chorioretinal scars.

a) Exposure Group

\begin{tabular}{|c|c|c|c|c|}
\hline & \multicolumn{2}{|c|}{ Rongelap and Ailingnae } & Utirik & Comparison \\
\hline MLT* & \multicolumn{2}{|c|}{$\begin{array}{c}6.66 \pm 3.72 \\
(61)^{* *}\end{array}$} & $\begin{array}{c}8.29 \pm 2.49 \\
(97)\end{array}$ & $\begin{array}{c}7.81 \pm 2.49 \\
(100)\end{array}$ \\
\hline$\%<4$ & \multicolumn{2}{|c|}{$18.0 \%$} & $3.1 \%$ & $4.0 \%$ \\
\hline MLT minus $<4$ & \multicolumn{2}{|c|}{$8.12 \pm 2.19$} & $8.55 \pm 2.03$ & $8.14 \pm 1.95$ \\
\hline & \multicolumn{3}{|c|}{ b) Island of Residence } & \\
\hline & Ebeye & Majuro & Rongelap & Utirik \\
\hline MLT & $\begin{array}{c}7.69 \pm 2.51 \\
(103)\end{array}$ & $\begin{array}{c}8.11 \pm 3.34 \\
(62\end{array}$ & $\begin{array}{c}7.22 \pm 3.23 \\
(87)\end{array}$ & $\begin{array}{c}8.48 \pm 2.56 \\
(172)\end{array}$ \\
\hline $\begin{array}{l}\text { MLT minus } \\
\text { Rongelap and } \\
\text { Ailingnae } \\
\text { Exposed }\end{array}$ & $\begin{array}{c}7.84 \pm 2.44 \\
(69)\end{array}$ & $\begin{array}{c}8.57 \pm 2.64 \\
\quad(53)\end{array}$ & $\begin{array}{c}7.62+2.84 \\
(71)\end{array}$ & $\begin{array}{c}8.49 \pm 2.36 \\
\quad(172)\end{array}$ \\
\hline
\end{tabular}

c) Age Distribution

\begin{tabular}{|c|c|c|c|}
\hline & $<10 \mathrm{yr}$ & $10-19$ yr & $>19 \mathrm{yr}$ \\
\hline $\begin{array}{l}\text { Rongelap and } \\
\text { Ailingnae }\end{array}$ & $\begin{array}{c}5.89 \pm 3.55 \\
(28)\end{array}$ & $\begin{array}{c}8.27 \pm 3.58 \\
\text { (11) }\end{array}$ & $\begin{array}{c}6.82 \pm 3.88 \\
(22)\end{array}$ \\
\hline Utirik & $\begin{array}{c}8.36 \pm 3.00 \\
(50)\end{array}$ & $\begin{array}{c}7.86 \pm 1.83 \\
(14)\end{array}$ & $\begin{array}{c}8.36 \pm 1.82 \\
(33)\end{array}$ \\
\hline Comparison & $\begin{array}{c}7.49 \pm 2.56 \\
(39)\end{array}$ & $\begin{array}{l}7.76 \pm 2.80 \\
(21)\end{array}$ & $\begin{array}{c}8.15 \pm 2.26 \\
(40)\end{array}$ \\
\hline
\end{tabular}


Table 3 (Continued)

Serum toxoplasma titers and chorioretinal scars.

d) Retinal Lesions

Rongelap and Ailingnae

(51)
Utirik

(98)
Comparison

(86)

\begin{tabular}{llll} 
Number & 2 & 1 & 2 \\
$\%$ & 3.9 & 1.0 & 2.3 \\
\hline
\end{tabular}

a) Compares exposure groups, including and excluding those persons with negative tests (titers <4).

b) Compares persons tested from the four islands visited by the medical team, including and excluding the exposf d from Rongelap and Ailingnae.

c) Compares exposure groups according to age at the time of exposure.

d) Compares exposure groups according to prevalence of chorioretinal scars.

* Mean log titer.

*:k Number of persons per group.

organism rather than to a deficient immune response. Table 3c shows that the lowest MLTs were present in Rongelap and Ailingnae persons who were $<10$ years and $>19$ years of age at the time of exposure. No apparent clinical consequences can be related to radiation; retinal lesions which may have been due to toxoplasmosis were similar among the four exposure groups (Table 3d).

The immune response of the exposed Marshallese will continue to receive attention because impaired immune function may place them at greater risk for infection and perhaps for tumor development. ${ }^{17}$ Knowledge of any such risk may have a direct bearing on medical care in future years. An evaluation of tuberculin and candida skin test responsiveness is currently under way.

There has been no evidence to date of autoimmune disorders. Rheumatoid arthritis has yet to be diagnosed with certainty in exposed persons. Two hundred fifty-seven persons (154 exposed and 103 unexposed) had serological evaluation for the presence of rheumatoid factor in 1981.82 . The only positive test found was in a 46-year-old Utirik man who had no evidence of rheumatic or collagen-vascular disease. This low prevalence of $0.4 \%$ contrasts with $5.2 \%$ reported for Maoris in New Zealand ${ }^{18}$ and $4 \%$ to $40 \%$ reported for various age groups in the U.S. ${ }^{19}$

\section{NONTHYROIDAL NEOPLASMS IN EXPOSED PERSONS}

\section{Pituitary Tumor}

A prolactinoma was diagnosed in 1981 and confirmed at surgery in 1982 in a 29 -year-old Utirik woman (No. 2160X) with galaciorrhea/amenorrhea. She had been exposed as an infant, but, in contrast to others, she left Utirik within 24 hours of the fallout and never returned to the atoll. The hospital summary of her surgical admission at the National Institutes of Health can be found in Appendix II. Retruspective assays of frozen sera saved on this patient from previous years revealed equivalent prolactin elevations as far back as 1975 (earlier sera were not available for testing). A photomicrograph of the surgically removed tumor is shown in Figure 3.

A nonfunctioning pituitary tumor had been diagnosed in 1976 in a 35-year-old exposed Rongelap woman and reported. ${ }^{1}$ The finding of a second clinically significant pituitary tumor in a total of 241 persons originally exposed to fallout (not including those in utero) represents a high incidence for these benign neoplasms. The incidence of clinically apparent pituitary tumors in the U.S. among persons under 45 years of age approaches $1 / 100,000$ population/year. ${ }^{20}$ The 


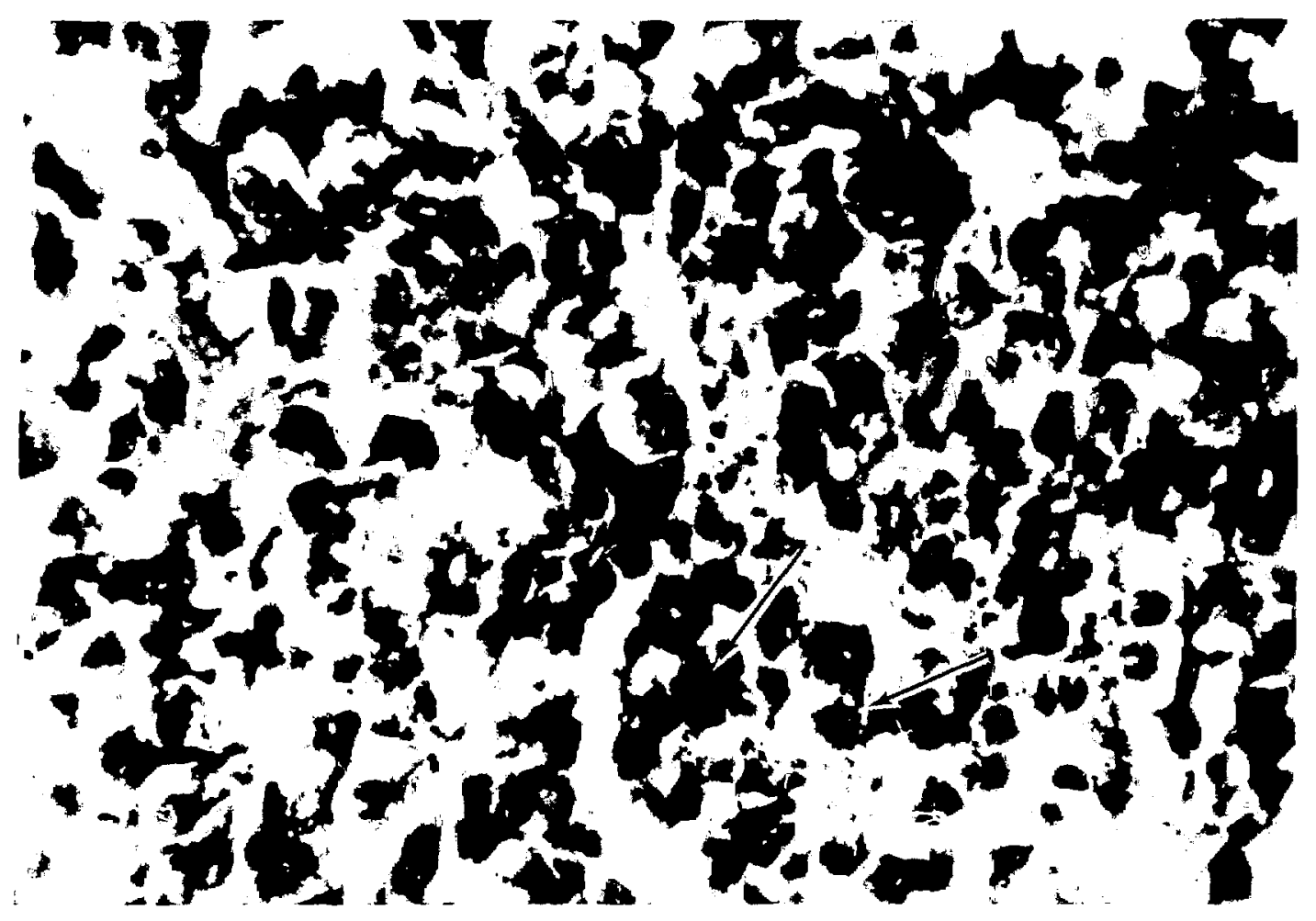

Figure 3. With immunofluorescent staining a dark cytoplasmic reaction product, indicated by the arrows, can be seen localizing prolactin in cells of the pituitary adenoma diagnosed in an exposed Utirik woman (No. 2160X). Prolactin-secreting cells have round-to-oval nuclei and distinct nucleoli ( $x 800)$.

incidence rate in the exposed Marshallese, based on a total of 4252 observation years, is 17.8 times that recently reported from Olmsted County, Minuesota. ${ }^{21}$ In the same study, women between the ages of 15 and 45 years had an incidence of $7.1 / 100,000$ persons per year. The incidence rate in exposed Marshallese women in the same age group (which includes the two patients discussed here) and based on 2176 observation years is 13.6 times the Olmsted County incidence.

The following table provides relative risks, $p$ values, and approximate confidence intervals for women between 15 and 44 years of age and for men and women combined who are less than 45 years of age, with Olmsted County used as the referent population:

\begin{tabular}{|c|c|c|c|c|c|c|}
\hline & & $\begin{array}{l}\text { Marshall } \\
\text { Islands }\end{array}$ & $\begin{array}{l}\text { Olmsted } \\
\text { County }\end{array}$ & $\begin{array}{c}\text { Relative } \\
\text { Risk }\end{array}$ & $\begin{array}{c}95 \% \\
\text { Confidence } \\
\text { Interval }\end{array}$ & $\mathrm{p}$ Value \\
\hline $\begin{array}{l}\text { Women } \\
15-44 \mathrm{yr}\end{array}$ & $\begin{array}{l}\text { Incidence: } \\
\text { Person Yrs: }\end{array}$ & $\begin{array}{r}2 \\
2176\end{array}$ & $\begin{array}{r}11 \\
163,096\end{array}$ & 13.6 & $(4,42)$ & 0.01 \\
\hline $\begin{array}{l}\text { Tot.Pop. } \\
<45 \text { yr }\end{array}$ & $\begin{array}{l}\text { Incidence: } \\
\text { Person Yrs: }\end{array}$ & $\begin{array}{r}2 \\
4252\end{array}$ & $\begin{array}{r}12 \\
454,472\end{array}$ & 17.8 & $(6,53)$ & $<0.001$ \\
\hline
\end{tabular}


While no cases have been diagnosed in a comparison population of unexposed Marshallese, the number of person years of observation is small (698 person years for women $15-44$ years of age, 1527 person years for the total population $<45$ years of age). This does not permit a meaningful statistical analysis of pituitary tumor incidence in the Marshall islands. Nevertheless, the absence of cases in the unexposed group does tend to support the results of the statistical analysis using data from Olmsted County.

Note that the observation years of the Marshallese cover the entire period from 1954 through 1982. No allowance is made in the incidence data for any latent period in tumor induction because there is no available information on what that might be. Nevertheless, it is clear that both tumors were present $21-22$ years after exposure.

The reason for the apperent increase in relative risk for pituitary tumors in the exposed Marshallese, if not cilance occurrence, is unknown. There are no prior reports of pituitary tumors being inducible by radiation in man, although they can be produced by external gamma radiation and apparently by boneseeking nuclides in experimental animals. ${ }^{22,23}$ No increase in pituitary neoplasms has been noted among survivors of the atomic bombings in Japan or among children who received cranial irradiation. ${ }^{24,25}$ While the development of two pituitary tumors in the relatively small population of exposed Marshallese may be evidence that certain types of radiation can induce pituitary neoplasia in man, the link is not a strong one, being a statistical phenomenon without a known biological basis.

Conceivably, pituitary neoplasia may have developed secondary to preexisting thyroid disease. Hyperplasia/adenoma formation of pituitary cells can result from thyroid hypofunction, 26,27 and hypothyroidism is sometimes associated with hyperprolactinemia and/or galactorrhea. ${ }^{2 B}$ Thyroid hypofunction has been noted among $16 \%$ of the exposed individuals from Rongelap. ${ }^{29}$ Hypothyroidism in general has not been associated with pituitary tumors in man, however, and the two Marshallese women were, for the most part, clinically and biochemically euthyroid when tested in the years preceding the pituitary tumor diagnoses (see Table 4 for exceptions).
Table 4

Serial thyroid-stimulating hormone* (TSH)

levels in two patients with pituitary tumors.

\begin{tabular}{ccc} 
& & \\
& Case No. $1^{* *}$ & Case No. 2 \\
\hline 1965 & 2.2 & \\
1967 & 1.0 & \\
1969 & 1.7 & $<2.5$ \\
1972 & 110 & \\
1973 & & \\
1974 & 1.0 & \\
1975 & 5.9 & 1.7 \\
1976 & $115^{\dagger}$ & 0.3 \\
1978 & 1.8 & $<2.5 \dagger$ \\
1979 & & \\
1981 & $<2.5$ & \\
\hline
\end{tabular}

- Normal values are less than $5 \mu \mathrm{U} / \mathrm{ml}$.

** Case No. 1 had a total thyroidectomy in 1969 for papillary carcinoma, and the elevated TSH levels in 1972 and 1976 were obtained when ihyroxin was discontinued prior to ${ }^{131} \mathrm{I}$ scanning.

$\dagger$ Year pituitary tumor was diagnosed.

It should be noted that occult pituitary tumors can be found in up to $27 \%$ of consecutive autopsies. $^{30,31}$ It is not clear, however, that such ubiquitous neoplasms are analogous to those which produce clinical disease.

Prolactinoma Survey. The most common pituitary tumor in humans is prolactinoma, its chemical marker being hyperprolactinemia., In 1981-82 serum prolactin levels were obtained on 174 of the 178 persons remaining in the exposed population (four persons have not been examined in several years). The prolactin radioimmunoassays were performed in the laboratory of Dr. P.R. Larsen, Peter Bent Brigham Hospital. One persistent and unexplained elevation was found in an 82-year-old woman in the Utirik group, who was 54 years of age at the time of exposure to fallout. It may be clinically pertinent that, although married, she had no children. Skull $x$ rays revealed a normal sella turcica. Because 1) there was no clinical evidence of a mass lesion, 2) she was of an advanced age, and 3) the serum prolactin elevation was minimal $(42 \mathrm{ng} / \mathrm{ml}$, with the upper range of normal for females in this population. based on two standard deviations above the mean, being $22 \mathrm{ng} / \mathrm{ml}$ ), further evaluation was not carried out. It is not certain, therefore, that 
she has a pituitary tumor, or, if so, whether or not it was the cause of her infertility.

\section{Meningioma}

A 43-year-old wornan (No. 2249) exposed on Utirik at age 15 had neurosurgery for a meningioma in 1982. The histology was interpreted at the. Armed Forces Institute of Pathoiogy as being "atypical" (Figure 4). A summary of her initial hospitalization is presented in Appendix III.

Comment. Pituitary tumors are included under benign neoplasms of endocrine glands in the International Classification of Diseases ( 9 th Revision, 1979). Because of unique characteristics related to anatomic placement, however, they have been included among the primary intracranial tumors in some studies. ${ }^{33,34}$ Clinically and at autopsy, no increase in pituitaiy adenomas has been found in Japanese atomic bombing survivors, ${ }^{24,35}$ children who received x-irradiation of the scalp for $T$. capitis, ${ }^{25,36}$ workers in industries involving radioactive materials, ${ }^{25,36}$ or proton-exposed Macaca mulatta. ${ }^{40}$ Nevertheless, all the cited studies reported an excess of primary brain tumors, including meningioma (although a correlation with radiation exposure was not always found). It is therefore premature io conclude that the two pituitary tumors and the meningioma diagnosed in exposed Marshallese have a common etiology because they are all intracranial. Nevertheless, this particular disease category clearly requires continued careful monitoring. One primary central nervous system tumor has occurred in the comparison population, an astrocytoma of the spinal cord diagnosed in 1982 it, a 28-year-old unexposed Rongelap woman.

\section{THYROID NEOPLASIA}

Methods. The thyroid nodule statistics in the 26-year report ${ }^{1}$ were based on a reassessment of all thyroid resections from 1963 through 1981. The signal contribution to that reassessment was provided by Dr. Donald Paglia (University of California, Los Angeles) who arranged a histopathologic classification which conformed to that of the World Health Organization. ${ }^{41}$ This led to greater unanimity in diagnosis than had previously existed. The medical program is fortunate in having four eminent consultant pathologists involved in that review who continue to evaluate prepared sections of recent thyroid lesions, ${ }^{*}$ and the World Health Organization classification has been retained.

Each year the exposed and comparison populations receive careful neck examinations by an endocrinologist or surgeon. Patients of all exposure groups requiring thyroid surgery continue to have their operations performed by Dr. Brown Dobyns at Cleveland Metropolitan Hospital. A comprehensive presurgery medical evaluation is provided at the Hospital of the Medical Research Center, Brookhaven National Laboratory.

Clinical followup of patients who have had surgery is carried out along the guidelines recommended by Dr. Jacob Robbins, Chief, Clinical Endocrinology Branch, the National Institutes of Health. The procedures used, apart from complete physical examinations provided annually, include thyroid scans, tests of thyroid function, and thyroglobulin determinations. Up to the present no mortality can be attributed to thyroid carcinoma in any of the operated persons, nor is there any evidence of residual malignant disease. There is, of course, the morbidity associated with decreased thyroid function in persons who have had surgical removal of large amounts of thyroid tissue, whether benign or malignant. Thyroid hormone supplementation (Synthroid) is routinely supplied to those individuals.

Thyroid hormone supplementation for all Rongelap-Ailingnae exposed, begun in 1965, has been continued. The reason for its use was to prevent the development of thyroid neoplasia. Thyroid nodules, however, have continued to occur over the years of surveillance, and it is not known if thyroid supplementation has delayed or prevented their development. A recent report suggests that such supplementation programs may be ineffective if begun more than a few years after radiation exposure. ${ }^{42}$ There is, however, another reason for cor.tinuing the current program, one that is based on the observation of subclinical hypothyroidism in a number of Rongelap individuals. ${ }^{29}$ This complication of their radiation exposure was detected only

\footnotetext{
* Dr. L.V. Ackerman, Health Sciences Center, SUNY, Stony Brook, NY; Dr. W.A. Meissner, New England Deaconess Hospital, Boston, MA; Dr. A.L. Vickery, Massachusetts General Hospital. Boston. MA; Dr. L,B. Woolner, Mayo Clinic, Rochester, MN.
} 
a)

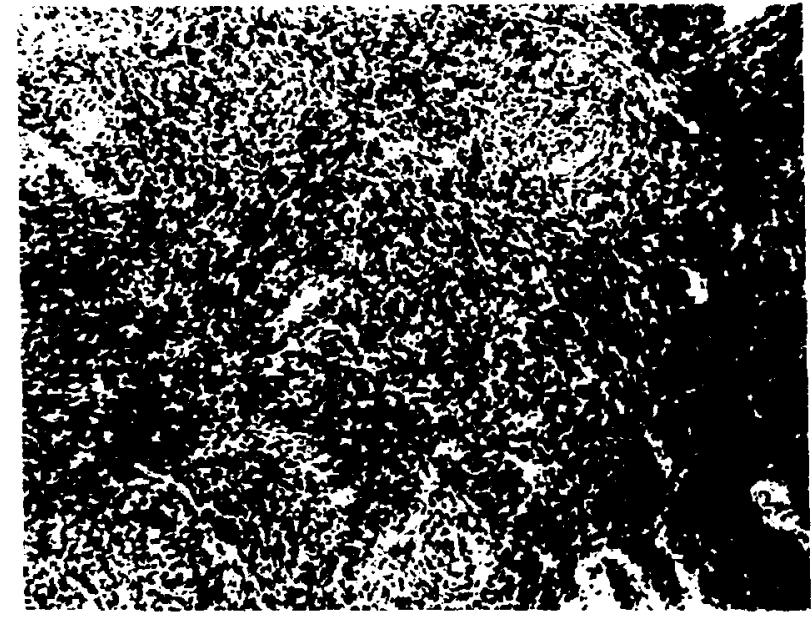

in

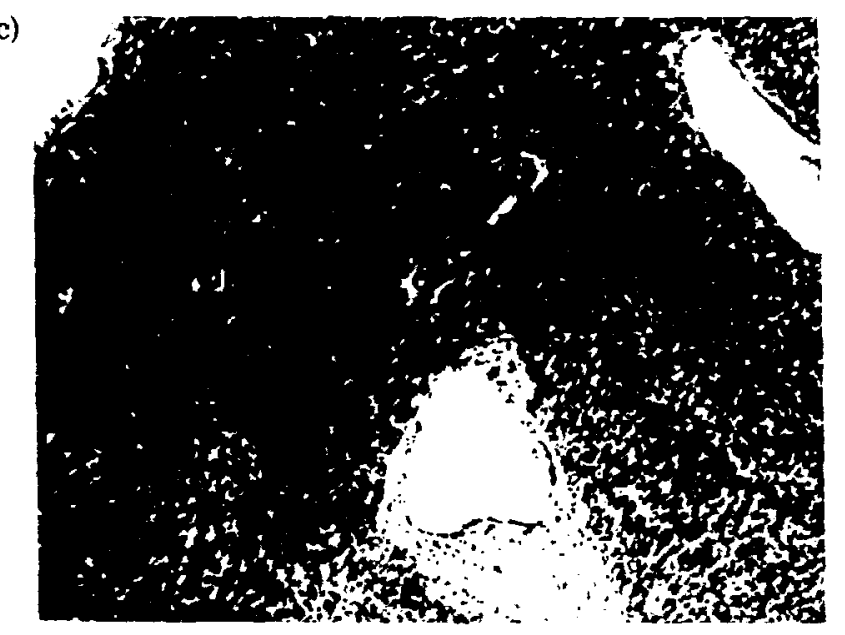

b)
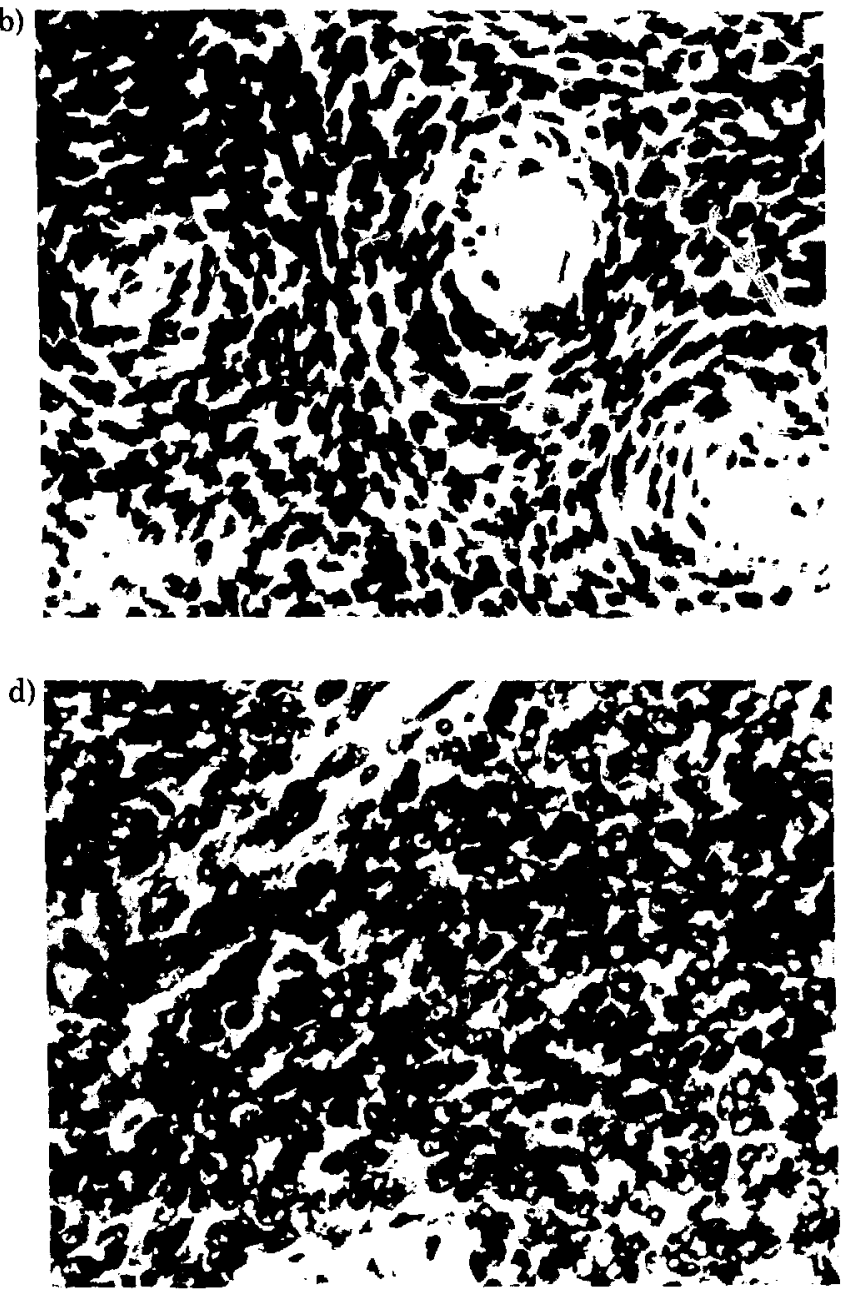

Figure 4 Photomicrographs of a meningioma diagnosed in an exposed Utirik woman (No. 2249). (a) and (b) represent low- and high-power views, respectively, of typical meningioma histology, whereas (c) and (d) show atypical areas with increased mitoses, nuclear pleomorphism, and hypercellularity. [Reviewed at the Armed Forces Institute of Pathology, Washington, DC (Dr. J.A. Gutierrez).] 
because thyroid-stimulating hormone levels have been performed annually on that population. (The Utirik population is cusrently tested every two years: no cases of nonsurgical thyroid hypofunction have been detected.) It is not known if the incidence of biochemically detectable thyroid hypofunction is increasing among the people of Rongelap, because 1) thyroid hormone replacement would have to be temporarily discontinued for testing, and 2) treatment for hypofunction would be the same supplementation they are currently receiving. It is not clear, therefore, that they would derive any clinical benefit from the information that might be obtained.

There is a continuing problem with noncompliance in taking Synthroid, even though the medical program provides and distributes the supplement. For 1980-1982 the average percent of elevated TSH values in the Rongelap group was $19 \%$ even though all persons in the group are advised to take suppressive doses of Synthroid. This is clearly a minimum estimate of noncompliance because many persons who are to take thyroid supplementation are euthyroid. Their noncompliance would therefore not be reflected in the TSH level. In 1980, when $24 \%$ had elevated TSH levels, another $18 \%$ with normal TSH levels admitted to either irregular compliance or none at all. This adds up to a $42 \%$ minimum estimate for noncompliance in that year. "Complete failure" to take prescribed medication may occur in $25.50 \%$ of outpatients in the U.S. ${ }^{43}$

Findings. One thyroid nodule was detected in a 28-year-old woman of the comparison population in 1981. Surgery proved it to be an ade. noma. This nodule, as well as those detected in 1980 , were included in the statistics of the 26 year report. ${ }^{1}$

Five persons underwent surgery in 1982 for suspected thyroid nodules. Significant pathology, however, was found in only three. Two of these were exposed persons from Rongelap (Nos. 36 and 65). They had adenomatous nodules removed in 1969 and 1966, respectively. The nodules detected in 1982 were also adenomatous nodules. They are therefore not included as new cases in the updated statistics. The other patient (No. 942) was a 65-year-old woman in the comparison population; three of four pathology consultants felt she had occult papillary carcinoma, while the fourth felt the lesion to be follicular carcinoma. An updated listing of all surgically removed lesions in the four exposure groups through 1982 is presented in Table 5.

A reassessment of absorbed radiation dose to the thyroid has now been completed and a summary of the results is presented in Appendix I. Dr. Robert Conard and Mr. Edward Les-

Table 5

Thyroid lesions diagnosed at surgery through $198 \%$.

\begin{tabular}{lcccc}
\hline & $\begin{array}{c}\text { Adenomatous } \\
\text { Nodules }\end{array}$ & Adenomas & Carcinomas & $\begin{array}{c}\text { Occult } \\
\text { Papillary } \\
\text { Carcinomas }\end{array}$ \\
\hline Rongelap (67)* & 17 & 2 & 4 & - \\
Ailingnae (19)* & 4 & - & - & 1 \\
Utirik (167)* & 10 & 2 & $3^{\dagger}$ & 1 \\
Comparison (227)** & 3 & 1 & 2 & $2^{\dagger \dagger}$ \\
\hline
\end{tabular}

NOT INCLUDED are the following unoperated (and therefore unconfirmed) nodules: Rongelap - 1; Ailingnae -1; Utirik - 1; comparison -5. INCLUDED are all consensus diagn oses of a panel of consultant pathologists; $t$ wo different lesions were detected in one person each from Rongelap, Ailingnae, and Utirik.

* Number of persons (including those in utero) who were originally exposed.

** This number includes all persons who have been included in the comparison group since 1957. Some have not been seen for many years; others have been added as recently as 1979.

$\dagger$ Equally divided opinion in one case; follicular carcinoma vs atypical adenoma.

t† Divided opinion in one case; occult papillary carcinoma vs follicular carcinoma. The same patient had a lymphocytic thyroiditis. 
sard (Safety and Environmental Protection Division, Brookhaven National Laboratory) have integrated the total clinical experience collected by the medical program relating thyroid neoplasia to radiation exposure. It should be noted that the unexposed population statistics were supplied by Dr. Conard and used in their calculations. Included are many individuals not in the comparison population. For example, "street surveys" for palpable thyroid lesions were carried out on the islands of Wotje and Likiep. From these and other unselected populations an approximate incidence of thyroid neoplasia for unexposed Marshallese has been derived. Table 5, on the other hand, is restricted to persons in the exposure groups defined at the outset of this report.

\section{INDIVIDUAL LABORATORY DATA}

As in earlier Brookhaven National Laboratory reports on the findings of the Marshall Islands medical program, a listing of individual laboratory test results obtained at the time of the annual examinations is provided in Appendix IV. This computer-generated listing has been the base for data analysis as performed on a VAX computer using BMDP statistical programs. The data presented were obtained at the time of the annual medical examinations in 1981 and 1982. Laboratory work performed at other times when clinically indicated is not included in the computer listing. For example, if a woman were found to have iron-deficiency anemia at the time of an annual examination and was treated with iron, her initial hemoglobin level and not the recovery value would be given in Appendix IV. All test results, however, are found in each person's active medical file.

\section{Acknowledgments}

The authors are grateful to Dr. R.A. Conard (for many years the Principal Investigator of the Marshall Islands Study), Dr. E.P. Cronkite (Senior Scientist, Brookhaven National Laboratory), Dr. B. Dobyns (Department of Surgery, Cleveland Metropolitan Hospital), Dr. P.R. Larsen (Massachusetts General Hospital), and Dr. J. Robbins (Chief, Clinical Endocrinology Branch, the National Institutes of Health) for their continuing support and clinical assistance to the Marshall Islands medical program. The excellent logistical support of Mr. William Stanley and his staif at the Pacific Area Support Office, Department of Energy, Honolulu, and of the captain and crew of Liktanur II is sincerely acknowledged. Of particular value to the Marshall Islands medical program has been the highly competent and empathic assistance of Ms. Jenuk Kabua, R.'.', and Mr. Helmer Emos, laboratory technician, Brookhaven National Laboratory Marshallese employees. The excellent secretarial services of Ms. Geraldine Callister and the editorial assistance of Ms. Mary Rustad are most appreciated. Dr. V.P. Bond, Associate Director, 'Brookhaven National Laboratory, kindly reviewed the manuscript.

\section{References}

The previous sixty-four Brookhaven National Laboratory Medical Department publications concerning the Marshall Islands fallout exposure are included in the following list of references. They are identified by an asterisk preceding the reference number. Those articles not cited in the text are placed in chronological order at th: $>$ conclusion of the listing. In addition, several chapters in the third, fourth, and fifth editions of the textbook Atomic Medicine (Williams and Wilkins, Baltimore, MD) were contributed by the Medical Department, Brookhaven National Laboratory, and contain Marshallese data.

*1. Conard, R.A. et Al., Review of Medical Findings in a Marshallese Population Twenty-Six Years After Accidental Exposure to Radioactive Fallout. BNL 51261, 1980.

*2. Conard, R.A., Meyer, L.M., Rall, J.E., Lowrey, A., BACh, S.A., Cannon, B., CARTER, E.L., EiChER, M., and HECh'TER, H., March 1957 Medical Survey of Rongelap and Utirik People Three Years After Exposure to Radioactive Fallout. BNL 501 (T-119), 1958.

3. Mantel, N., Evaluation of survival data and two new rank order statistics arising in its consideration. Cancer Chemother. Rep. 50: 163.70 (1966).

4. Breslow, N., A generalized Kruskal-Wallis test for comparing $\mathbf{k}$ samples subject to unequal patterns of censorship. Biometrika 57: $579-94$ (1970).

5. Grimson, R. And Quade, D., A simple test for equally likely random responses in a sequence 
of Bernoulli trials. Communications in Statis. tics (in press).

6. Blaisdell, R.K. And Amamoto, K., Review of ABCC hematologic studies, 1947-59, Tech. Rept., pp. 25-66, Atomic Bomb Casualty Commission, 1966.

7. Upton, A.C. and Lushbaugh, C.C., The pathological anatomy of total-body irradiation, in: Atomic Medicine, p. 158, 5th edition, Williams and Wilkins Co., Baltimore, MD, 1969.

8. Garcia, J.F., Ebbe, S.N., Hollander, L., Cutting, H.O., Miller, M.E., AND CRONKite, E.P., Radioimmunoassay of erythropoietin: circulating levels in normal and polycythemic human beings. J. Lab. Clin. Med. 99: 624-35 (1982).

9. WILLJAMs, W.J., Examination of the blood, in: Hematology, p. 10, 3rd Edition; Williams, W.J., Beutler, E., Erselev, A.J., AND Lichtman, M.A. (Eds.), McGraw-Hill Book Co., New York, 1983.

10. Committee on the Biological Effects of Ionizing Radiations, in: The Effects on Populations of Exposure to Low Levels of Ionizing Radia. tion: 1980, pp. 397-9, National Academy Press, Washington, DC, 1980.

*11. Conard, R.A. ET AL., Medical Survey of Rongelap People Five and Six Years After Exposure to Fallout (with an addendum on vegetation), BNL 609 (T-179), 1960.

*12. ConArd, R.A. ET AL., Medical Survey of the People of Rongelap and Utirik Islands Thirteen, Fourteen, and Fifteen Years After Exposure to Fallout Radiation: March 1967, March 1968, and March 1969. BNL 50220 (T-562), 1970.

*13. Conard, R.A. et Al., A Twenty-Year Review of Medical Findings in a Marshallese Population Accidentally Exposed to Radioactive Fallout. BNL 50424, 1975.

14. Ruskin, J. And Remington, J.S. Toxoplasmosis in the compromiscd host. Ann. Intern. Med. 84: 193.9 (1976).

15. WAllace, G.D., Serologic and epidemiologic observations on toxoplasmosis on three Pacific atolls. Am. J. Epidemiol. 90: 103-11 (1969).

16. Wallace, G.D., The prevalence of toxoplasmosis on Pacific Islands, and the influence of ethnic group. Am.J. Trop. Med. Hyg. 25: 48-53 (1976).

17. PENN, I., Depressed immunity and the development of cancer.J. Exp. Immunol. 46:459-74 (1981).

18. PrIOR, I., Epidemiology of rheumatic disorders in the Pacific with particular emphasis on hyperuricemin and gout. Semin. Arthritis Rheum. 11: 213-29 (1981).

19. Gilliland, B.C. AND Mannik, M., Rheumatoid arthritis, in: Principles of Internal
Medicine, p. 1874, 9th Edition, ISSELBACHER, K.J., Adams, R.D., Braunwald, E.. PetersDORF, R.G., AND WILSON, J.D. (Eds.), 1980.

20. GolD, E.G., Epidemiology of pituitary adenomas. Epidemiol. Rev. 8: 163-83 (1981).

21. Annegers, J.F., Coulam, C.B., Abboud, C.F., LAws, E.P., JR., AND Kurland, L.T., Pituitary adenoma in OImsted County, Minnesota, 1935-1977. Mayo Clin. Proc. 53: 641-3 (1978).

22. Furth, J., Haran-Ghera, N., Curtis, H.J., AND BufFETT, R.F., Studies on the pathogenesis of neoplasms by ionizing radiation. Cancer Res. 19: 550-6 (1959).

23. Moskalev, Y.I., Stretsova, V.N., AND BulDAKov, L.A., Late effects of radionuclide damage, in: Delayed Effects of Bone-Seeking Radionuclides, pp. 489-509, MAYs, C.W. ET AL. (Eds.), University of Utah Press, 1969.

24. Kato, H. ANd Schull, W.J., Studies of the mortality of A-bomb surviors. 7. Mortality, 1950-1978: Part I. Cancer Mortality. Radiat. Res. 90: 395-432 (1982).

25. Modan, B., Baidatz, D., Mart, H., Steinitz, R., AND LEvin, S.G., Radiation-induced head and neck tumors. Lancet i: $277-9$ (1974).

26. Russfield, A.B., Histology of the human hypophysis in thyroid disease - hypothyroidism, hyperthyroidism, and cancer. J. Clin. Endocrinol. Metab. 15: 1393-1408 (1955).

27. Bijos, S.T., Ridgway, E.C., Kourides, I.A., AND MALOOF, F., Spectrum of pituitary alterations with mild and severe thyroid impairment. J. Clin. Endocrinol. Metab. 46: 317-25, (1978).

28. Contreras, P., Generini, G., Michelsen, G., Pumarino, H., and Campino, C., Hyperprolactinemia and galactorrhea: Spontaneous versus iatrogenic hypothyroidism. J. Clin. Endocrinol. Metab. 53: 1036.9 (1981).

*29. Larsen, P.R., Conard, R.A., KNudsen, K., RobBins, J., WOLFF, J., RALL, J.E., Nicoloff, J.T., And DoByns, B.M., Thyroid hypofunction after exposure to fallout from a hydrogen bomb explosion. JAMA 247: 1571-5 (1982).

30. Costello, R.T., Subclinical adenoma of the pituitary gland. Am. J. Pathol. 12: 205-15 (1936).

31. Burrows, G.N., Wortzman, G., RewCastle, N.B., Holgate, R.C., and Kovacs, K., Microadenomas of the pituitary and abnormal sellar tomograms in an unselccted autop. sy series. New Engl. J. Med. 304: 156-8 (1981).

32. KoHLER, P.O., Diseases of the hypothalamus and anterior pituitary, in: Principles of Inter. nal Medicine, p. 1680, 9th edition, IssELBaCHER, K.J., Adams, R.D., Braunwald, E., Petersdorf, R.G., and Wilson, J.D. (Eds.), McGraw.Hill, New York, 1980. 
33. Kernohan, J.W. and Sayre, G.P., Tumors of the central nervous system. Fascide 35: Allas of Tumor Pathology, Washington, D.C., Armed Forces Institute of Pathology, 1952.

34. Schoenberg, B.S., Christine, B.W., and Whisnant, J.P., The descriptive epidemiology of primary intracranial neoplasms: The Connecticut experience. Am. J. Epidemiol. 104: 499-5i0 (1976).

35. Seyama, S., Ishimaru, T., IlJima, S., and Mori, K., Primary Int:acranial Tumors Arong Atomic Bomb Survivors and Contruls, Hiroshima and Nagasaki, 1961-1975. Radiation Effects Research Foundation Report (RERF T'R 15-79).

36. Shore, R.E., Albert, R.E., and Pasternack, B.S., Follow-up study of patients treated by x-ray epilation for Tinea capitis. Arch. Environ. Health 31: 17-28 (1976).

37. Hadjimichael, O.C., OstFeld, A.M., D'Atria, D.A., AND Brubaker, R.L., iMortality and cancer incidence experience of employees in a nuclear fuels fabrication plant. J. Occup. Med. 25: $48-61$ (1983).

38. Lushbaugh, G.C., The development and present state of the DOE health and mortality studies in: Proc. DOE Radiation Contractors Workshop, U.S. Dept. of Energy, pp. 1-36, April 1982.

39. Reyes, M., Wilkinson, G., Tietjen, G., Voelz, G., Acquavella, J., And Bistline, R., CascCostirol Study of Brain Tumors Among White Males Employed at the Rocky Flats Plant. LA-9804-MS, Los Alamos National Laboratory, 1983.

40. KRUPP, J.H., Nine-year mortality experience in proton-exposed Macaca mulatta. Radiat. Res. 67: 244-51 (1976).

41. Hedinger, C. AND Sobin, L.H., Histological Typing of Thyroid Tumors, World Health Organization, Geneva, 1974.

42. DeGroot, L.J., Reilly, M., Pinnameneni, K., AND RefEToff, S., Retrospective and prospective study of radiation-induced thyroid disease. Am. J. Med. 74: 852-62 (1983).

43. BLACKwell, B., Drug therapy; patient compliance. New Engl. J. Med.289:249-52 (1973).

*44. Cronkite, E.P., Bond, V.P., and Dunham, C.L., Some Effects of Ionizing Radiation on Human Beings. AEC-TID 5358, 1956.

*45. Cronkite, E.P., Dunham, C.L., Griffin, D., MCPHERSON, S.D., AND WOODWARD, K.T., Twelve-Month Postexposure Survey on Marshallesc Ea posed to Fallout Radiation. BNL 384 (T-71), 1955.

*46. Conard, R.A., Cannon, B., Huggins, C.E., Richards, J.B., AND LoWrey, A., Medical Survey of Marshallese Two Years After Exposure to Fallout Radiation. BNL 412 (T-80), 1956.
*47. ConARD, R.A., The effects of fallout radiation on the skin, in: The Shorter-Term Biological Hazards of a Fallout Field, pp. 135-42, AEC. DOD, U.S. Government Printing Office, Washington, DC, 1956.

*48. Conard, R.A. ET AL., Response oi human beings accidentally exposed to significant fallout radiation from a thermonuclear explosion (summary), in: Prcgress in Radiobiology, pp, 491-3, Mitchel.L, J.S., Holmes, B.E., AND Smith, G.G. (Eds.), Oliver anid Boyd, Edinborough, London, 1956.

*49. Conard, K.A., Cannon, B., Huggins, C.E., Richards, J.B., AND Lowrey, A., Medical survey of Marshallese two years after exposure to fallout radiation. J. Am. Med. Assoc. 164: 1192-7 (1957).

*50. Conard, R.A., Three year medical survey of the Marshallese people exposed to fallout in March 1954. Radiat. Res. 3: 309 (1957).

*51. Conard, R.A., Robertson, J.S., Wolins, W., Meyer, L.M., Sutow, W.W., and Hechter, H., Effects of fallout radiation on a human population. Radiat. Res. Suppl. 1: 280-95 (1959).

*52. Sussman, L., Meyer, L.M., and Conard, R.A., Blood groupings in Marshallese. Science 129: $644-5$ (1959).

*53. Conard, R.A., Robertson, J.S., Meyer, L.M., Sutow, W.W., Wolins, W., LOWREY, A., URSCHEL, H.C., BarTon, J.M., GOLDMAN, M., Hechter, H., Eicher, M., CARver, R.K., AND PotTER, D.W., Medical Survey of Rongelap People, March 1958, Four Years After Expo. sure to Fallout. BNL 534 (T-135), 1959.

*54. ConARD, R.A., Medical survey of Marshallese people five years after exposure to fallout radiation. Int. J. Radiat. Biol. Suppl. 1: $269 \cdot 81$ (1960).

*55. Conard, R.A., Meyer, L.M., Sutow, W.W., Blumberg, B.S., Lowrey, A., AND CoHN, S.H., Medical status of Marshall Islanders in 1959 , five years after exposure to fallout radiation. Nucl.-Med. 1: 314-30 (1960).

*56. Cohn, S.H., Robertson, J.S., And Conard, R.A., Radioisotopes and environmental circumstances: The internal radioactive contamination of a Pacific island community exposed to local fallout, in: Radioisotopes in the Bio. sphere, Chapter 21, pp. 306-30, CALDECOTT, R.S. AND SN YDER, L.A. (Eds.), Publ. by Center for Continuation Study, University of Minnesota, 1960.

*57. Conard, R.A., An attempt to quantify some clinical criteria of aging. J. Gerontol. 15: 35865 (1960).

*58. ConARD, R.A., The biological hazards of a fallout field, in: Radioactivity in Man, pp. 249. 65, Meneely, G.E. (Ed.), Thomas, C.C., Springfield, IL, 1961. 
*59. Conard, R.A., Meyer, L.M., Cohn, S., Sutow, W.W., MCDonald, H.E., Karnofsky, D., JAFfe, A.A., And RJklon, E., Medical Survey of Rongelap People Seven Years After Exposure to Fallout. BNL 727 ('I'-260), 1962.

*60. Cohn, S.H., Conard, R.A., Gusmano, E.A., AND RoBERTSON, J.S., Use of a portable wholebody counter to measure internal contamina. tion in a fallout-exposed population. Health Phys. 9: 15-23 (1963).

*61. Conard, R.A., Meyer. L.M., Sutow, W.W., Moloney, W.C., Lowrey, A, Hicking, A. AND RIKLoN, E., MedicaLSurvey of Rongelap People Eight Years After Exposure to Fallout. BNL 780 (T-296), 1963.

*62. Lyon, H.W., Glassford, K.F., and Conard, R.A., Long-term intraoral findings in humans after exposure to total body irradiation from sudden radioactive fallout. I. Five year postdetonation studies. J. Am. Dcnt. Assoc. 68: 49-56 (1964).

*63. Conard, R.A., Effect of acute falluat radiation on a Marshall Island population. Presented at Second Annu. Conf. on Science and Human Survival. Congr. of Scientist on Survival. Am. Muscum Natural History, June 15, 1963. BNL, 7145.

*64. Cohn, S.H., Conikd, R.A., Robertson, J.S. AN1) Gusmano, E.A., Measurement of $\mathrm{Sr}^{90}$ and $\mathrm{Cs}^{137}$ in a population exposed to fallout, in: IAEA Symp. on Assessment of Radioac. tive Body Burdens in Man, Heidelbers. Germany, May 1964.

*65. Conard, R.A. Meyer, L.M., Sutow, W.W., Moloney, W.C., Cannon, B., Hicking, A., AND RikLon, E., Medical survey of the people of Rongelap and Utirik Islands, nine years after exposure to fallout radiation (March 1963). Interim Report, BNL 7766.

*66 JAMEs, R.A., Estimate of Radiation Dose to Thyroids of Rongelap Children Following the BRAVO Event. Lawrence Radiation Laboratory Report, UCRL-12273, 1964.

*67. Hakdy, E.P., JR., Rivera, J., and ConaRI), R.A., Cesium-137 and strontium-90 retention following an acute ingestion of Rongelap food, in: Radioactive Fallout From Nuclear Weap. ons Tests, pp. 743-57, KLEMENT, A.W., JR., (Ed.), AEC Conf. 765, 1965.

*68. Sutow, W.W., Conard, R.A., and Griffith, K.M., Growth status of children exposed to fallout radiation on Marshall Islands. Pediatrics 36: $721-31$ (1965).

*69. Conard, R.A. and Hicking A., Medical findings in Marshallese people exposed to fallout radiation: Results from a ten-year study. J. Am. Med. Assoc. 192: 457-9 (1965).

*70. Sutow, W.W. ANu Conar1), R.A., Effects of ionizing radiation in children. $J$. Pediatrics 67: 658-73 (1965).
*71. Conard, R.A., Meyer, L.M., Sutow, W.W., Lowrey, A., Cannon, B., Moloney, W.C., Watne, A.C., Carter, R.E., Hicking, A., Hammerstrom, R., Bender, B., Lanwi, I., Riklon, E., And Anjain, J,, Medical Survey of the People of Rongelap and Utirik Islands Nine and Ten Years After Exposure to Fallout Radiation. BNL 908 (T'-371), 1965.

*72. Rall, J.E. aNd Conard, R.A., Elevation of the serum protein-bound iodine level in in habitants of the Marshall Islards. Am. J. Med. 40: 883-6 (1966).

*73. Conard, R.A., Meyer, L.M., Sutow, W.W., Robertson, J.S., Jesseph, J.E., RaLL, J.E., Eicher, M., Gusmano, E.A., Hickirg, A., AND Lanwi, 1., Medical survey of the people of Rongelap Island, eleven years after exposure to fallout radiation (March 1965). Interim Report, BNL 9698.

*74. Rorertson, J.S., Conard, R.A., and GusMANO, E., Radionuclide body burdens in the Rongelap population, Third Int. Congr. of Radiation Res.. Cortina, Italy, June 26 . July 2, 1966.

*75. Conand, R.A., Rall, J.E., anis Sutow, W.W., Thyroid nodules as a late sequela of radioactive fallout in a Marshall Island population exposed in 1954. New Engl.J. Med.274: 1392. 9 (1966).

*76. Conard, R.A., Lowrey, A., Eicher, M., Thompson, K., And Scott, W.A., Ageing studies in a Marshallese population exposed to radioactive fallout in 1954, in: Radiation and Ageing, pp. 345-60, Lindop, P.J. and Sacher, G.A., (Eds.), Taylor and Francis, London, 1966.

*77. Lisco, H. and Conard, R.A., Chromosome studies on Marshallese people exposed to fallout radiation. Science 157: $445-7$ (1967).

*78. Conar1, R.A., Further development of thyroid nodules in a Marshallese population accidentally exposed to radioactive fallout in 1954. Suffolk County Med. Soc. Bull., p. 25, March 1967.

*79. Robbins, J., Rall, J.E., ANi Conard, R.A., Late effects of radioactive iodine in fallout. Ann. Intern. Med. 66: 1214-42 (1967).

*80. Consr1, R.A., Late effects of radioactive fallout on the thyroid gland in a Marshallese population, in: Proc. Am. Assot. Adv. Science, New York, NY, Dec. 26-28, 1967.

*81. Conard, R.A., Meyer, L.M., Sutow, W.W., Robertson, J.S., Rail, J.E., Rolbins, J., Jesseph, J.E., Deisher, J.B., Hicking, A., Lanwi, I., Gusmano, E.A., and Eicher, M., Medical Survey of the Pcople of Rongelap and Utirik Islands Eleven and Twelve Years After Exposure to Fallout Radiation, March 1965 and March 1966. BNL 50029 (T446), 1967. 
*82. ConARD, R.A. (Abstract). Acute and delayed effects of fallout radiation on man. Radiat. Res. 35: 498 (1968).

*83. Conard, R.A., Sutow, W.W., Colcock, B.P., Dobyns, B.M., and Paglia, D.E., Thyroid nodules as a late effect of exposure to fallout, in: Radiation-Induced Cancer, pp. 325-36, IAEA, Vienna, 1969.

*84. Sutow, W.W. And Conard, R.A., The effects of fallout radiation on Marshallese children, in: Radiation Biology in the Fetal and Juvenile Mammal, pp. 661-73, Sıkov, M.R. AND Mahlum, D.D. (Eds.), USAEC, 1969.

*85. Cunard, R.A., Dobyns, B.M., and Sutow, W.W., Thyroid neoplasin as late effect of exposure to radioactive iodine in fallout. $J . A m$. Med. Assoc. 214: 316-24 (1970).

*86. Conard, R.A., Demoise, C.F., Scotr, W.A. AND MAKAR, M., Immunohematological studies of Marshall Islanders sixteen years after fallout radiation exposure. J. Gerontol. 26: 28-36 (1971).

*87. Conari, R.A. (Abstract). Possible radiationinduced aging as measured by immunohematological changes in a Marshallese population exposed to radioactive fallout. Presented at IVth Int. Congr. Radiat. Res., Evian, France, June 28-July 4, 1970.

*88. ConARD, R.A., Effects of ionizing radiations on aging and life shortening in human populations, in: Frontiers Radiat. Thera. Oncol. 6: 486-98 (1972).

*89. Beasley, T.M., Held, E.E., and Conard, R.A., Iron-55 in Rongelap people, fish and soils. Health Phys. 22: 245.50 (1972).

*90. Demoise, C.F. AND Conard, R.A., Effects of age and radiation exposure on chromosomes in a Marshall Island population. J. Gerontol. 27: 197-201 (1972).

*91. Conśru, R.A., Acute myelogenous leukemia following fallout radiation exposure. $J$. Am. Med. Assoc. 232: 1356-7 (1975).

*92. Neel, J.V., Ferrell, R.E., and Conard, R.A., The frequency of "rare" protein variants in Marshall Islanders and other Micronesians. Am. J. Hum. Genet. 28: 262.9 (1976).
*93. Popp, R.A., Bailiff, E.G., Hirsch, G.P., AND CoNARD, R.A., Errors in human hemoglobin as a function of age. Interdiscip. Top. Gerontol. 7: 209-18 (1976).

*94. ConARD, R.A., Summary of thyroid findings in Marshallese 22 years after exposure to radioactive fallout, in: Radiation-Associated Thyroid Carcinoma, pp. 241-56, DeGroot, L.J., ET AL. (Eds.), Grune and Stratton, New York, 1977.

*95. Larsen, P.R., Conard, R.A., Knudsen, K., RobBins, J., WolfF, J., RALL, J.E., AND DOBYNS, B.M., Thyroid hypofunction appearing as a delayed manifestation of accidental exposure to radioactive fall-out in a Marshallese population. IAEA Meeting, The Late Biological Effects of Ionizing Raciation, Vienna, Austria, Vol. 1, pp. 101-15, 1978.

*96. Conard, R.A. The 1954 Bikini Atoll incident: An update of the findings in the Marshallese people, in: The Medical Basis for Radiation Accident Preparedness, pp. 55-8, HubNer, K.F. AND Fry, S.A. (Eds.), Elsevier North Holland, Inc., 1980.

*97. Sutow, W.W., Conard, R.A. And Thompson, K.H., Thyroid injury and effects on growth and development in the Marshallese children accidentally exposed to radioactive fallout. Cancer Bull. 34: 90-6 (1982).

*98. Lessard, E.T. And ConarD, R.A., Exposure to fallout: The radiation dose experience at Rongelap and Utirik atolls, in: Proc. 7th Int. Congr. Radiat. Res.. Vol. C., pp. C8-09, Broerse, J.J., Barendsen, G.W., Kal, H.B., AND VAN Der Kogel, A.J. (Eds.), Martinus and Nijhoff, Amsterdam, 1983.

*99. ConARD, R.A., Late radiation effects in Marshall Islanders exposed to fallout twentyeight years ago, in: Radiation Carcinogenesis, Epidemiology and Biologic Significance, Bolce, J.D. and Fraumoni, J.F., JR. (Eds.), Raven Press Inc., New York (in press).

. *100. Lessard, E.T. and Conard, R.A., Protracted exposure to fallout: The Rongelap and Utirik experience. Health Phys. J. 46 (1984). 


\section{Thyroid-Absorbed Dose for Rongelap and Utirik Residents}

Persons who were present on March 1, 1954, at Rongelap Island, Rongelap Atoll, Sifo Island, Ailingnae Atoll, and Utirik Island, Utirik Atoll in the Marshall Islands have been examined by medical specialists to determine if any observable effects occurred as a result of exposure to radioactive fallout from the Pacific weapon test known as Operation Castle BRAVO. Medical specialists have reported short-term effects exhibited over a period of many months and possible long-term effects exhibited over many years. A study was undertaken to reexamine thyroidabsorbed dose estimates for people who were exposed accidentally at Rongelap, Sifo, and Utirik Islands. Four methods were examined: 1) reevaluation of radiochemical analysis to relate results from pooled urine to intake, retention, and excretion functions; 2) analysis of neutron-irradiation studies of archival soil samples to estimite areal activities of the iodine isotopes; 3 ) analysis of source term, weather data, and meteorology functions predicting atmospheric diffusion and fallout deposition to estimate airborne concentrations of the iodine isotopes; and 4) reevaluation of radioactive fall-out contaminating a Japanese fishing vessel in the vicinity of Rongelap Island on March 1, 1954, to determine fallout components. Details of this research are to be published in a Brookhaven National Laboratory report by Lessard et al. ${ }^{1}$

The original estimate of external whole-body dose from the acute exposure was 1.75 gray ( 175 rad) at Rongelap and 0.14 gray (14 rad) at Utirik. $^{2}$ The first estimate of thyroid dose from internal emitters in Rongelap people was 100 to 150 rep. ${ }^{2}$ Thus the first estimate of total thyroidabsorbed dose was 2.68 to 3.15 gray (268 to 315 $\mathrm{rad}$ ) for Rongelap people in general and for internal plus external exposure.

In 1964, three teenage girls who were exposed in 1954 underwent surgery for benign thyroid nodules. In 1964, the 3- to 4-year-old child thyroid dose was reexamined by James on the basis of.1) urine bioassay results and 2) a range of values for thyroid burden of ${ }^{131} I$, thyroid mass, and uptake retention functions for iodine. ${ }^{3}$ In addition two modes of intake were considered, inhalation and ingestion. For 3- to 4-year-old girls the extreme range of thyroid dose from internal emitters was estimated at 2 to 33 gray (200-3300 rad). The most probable total thyroid dose was in the range of 7 to 14 gray (700-1400 $\mathrm{rad}$ ). The James estimate of most probable total thyroid-absorbed dose to the child was 2 to 5 times higher than the estimate reported by Cronkite for Rongelap people.

The value for the James estimate of total thyroid dose was extrapolated to other ages and to the Utirik people and reported along with medical effects by Conard. ${ }^{4}$ The number of radiationinduced thyroid lesions per million-person rad years at risk was tabulated by Conard for the Rongelap- and Utirik-exposed populations. It was clear that the risks of radiation-induced benign and cancerous lesions were not comparable between the two atolls for any age grouping. The thyroid cancer risk for the Japanese population exposed at Nagasaki and Hiroshima reported by the National Research Council's Committee on the Biological Effects of Ionizing Radiation was 1.89 excess cases per millionperson rad years of tissue dose. ${ }^{5}$ This parameter was 7.0 at Rongelap and 17.8 at Utirik for the 10-year and older age grouping in $1974 .^{4}$

Variation in risk of radiation-induced thyroid cancer between atolls and the difference when compared to other irradiated groups became an important scientific and health-related question with considerable political overtones. Early in 1977, Bond, Borg, Conard, Cronkite, Greenhouse, Naidu, and Meinhold, all members of Brookhaven National Laboratory, and Sondhaus, University of California, College of Medicine, initiated a reexamination of the technical issues. In 1978, formal program objectives and funding were supplied by the Department of Energy's Division of Biological and Environmental Research.

In June 1978, the Meteorology Division at Lawrence Livermore National Laboratory was subcontracted to provide a computer simulation of the dispersion, transport, and deposition of fallout from the 1954 atmospheric nuclear test, BRAVO. A subcontract to provide neutron activation analysis of archival soil samples was given to the Radiological Sciences Department, Batelle-Pacific Northwest Laboratory. Soil samples were provided by Seymour, the director 
of the University of Washington's Laboratory of Radiation Ecology.

During 1980, members of Brookhaven National Laboratory researched the protracted exposure to fallout at Rongelap and Utirik Atolls. The time interval of interest was from the time each population returned to their home atoll up to $\mathbf{5 0}$ years later. The nuclides consid- ered were ${ }^{137} \mathrm{Cs},{ }^{60} \mathrm{Co},{ }^{90} \mathrm{Sr},{ }^{55} ? \mathrm{e},{ }^{65} \mathrm{Zn}$, and ${ }^{239} \mathrm{Pu}$. The thyroid-absorbed dose froin these sources was negligible relative to the thyroid dose committed during the first few days after the accidental exposure.

The thyroid-absorbed dose tabulated here was estimated from results on ${ }^{131}$ I activity excreted in urine and the specific nuclide composition of

Table 1

Estimated Radioiodine and Radiotellurium Thyroid-Absorbed Dose and Corresponding Age

\begin{tabular}{|c|c|c|c|c|c|c|c|c|}
\hline \multirow[b]{2}{*}{ Age } & \multirow[b]{2}{*}{${ }^{135} I$} & \multirow[b]{2}{*}{${ }^{134} I$} & \multicolumn{2}{|c|}{ Rongelap Island, rad } & \multirow[b]{2}{*}{${ }^{131} I$} & \multirow[b]{2}{*}{${ }^{131} \mathrm{Te}$} & \multirow[b]{2}{*}{${ }^{131 m^{T e}}$} & \multirow[b]{2}{*}{ Total } \\
\hline & & & ${ }^{133} \mathbf{I}$ & ${ }^{132} I$ & & & & \\
\hline Adult Male & $1.9 \times 10^{2}$ & $3.0 \times 10^{0}$ & $5.5 \times 10^{2}$ & $7.3 \times 10^{0}$ & $1.3 \times 10^{2}$ & $1.2 \times 10^{2}$ & $1.3 \times 10^{1}$ & $1.0 \times 10^{3}$ \\
\hline Adult Female & $2.0 \times 10^{2}$ & $3.5 \times 10^{0}$ & $5.7 \times 10^{2}$ & $7.4 \times 10^{2}$ & $1.4 \times 10^{2}$ & $1.2 \times 10^{2}$ & $1.3 \times 10^{1}$ & $1.1 \times 10^{3}$ \\
\hline 14 Year Old & $2.8 \times 10^{2}$ & $4.0 \times 10^{0}$ & $7.5 \times 10^{2}$ & $1.0 \times 10^{1}$ & $2.0 \times 10^{2}$ & $1.7 \times 10^{2}$ & $1.9 \times 10^{1}$ & $1.4 \times 10^{3}$ \\
\hline 12 Year Old & $3.0 \times 10^{2}$ & $4.8 \times 10^{0}$ & $9.1 \times 10^{2}$ & $1.1 \times 10^{1}$ & $2.1 \times 10^{2}$ & $1.9 \times 10^{2}$ & $1.9 \times 10^{1}$ & $1.6 \times 10^{3}$ \\
\hline 9 Year Old & $3.7 \times 10^{2}$ & $6.2 \times 10^{0}$ & $1.1 \times 10^{3}$ & $1.4 \times 10^{1}$ & $2.4 \times 10^{2}$ & $2.3 \times 10^{2}$ & $2.3 \times 10^{1}$ & $2.0 \times 10^{3}$ \\
\hline 6 Year Old & $4.5 \times 10^{2}$ & $8.0 \times 10^{0}$ & $1.3 \times 10^{3}$ & $1.6 \times 10^{1}$ & $2.8 \times 10^{2}$ & $2.7 \times 10^{2}$ & $2.6 \times 10^{1}$ & $2.4 \times 10^{3}$ \\
\hline 1 Year Old & $9.5 \times 10^{2}$ & $1.7 \times 10^{1}$ & $2: 8 \times 10^{3}$ & $3.4 \times 10^{1}$ & $5.8 \times 10^{2}$ & $5.7 \times 10^{2}$ & $5.7 \times 10^{1}$ & $5.0 \times 10^{3}$ \\
\hline Newborn & $4.9 \times 10^{1}$ & $8.3 \times 10^{-1}$ & $1.4 \times 10^{2}$ & $1.8 \times 10^{0}$ & $3.3 \times 10^{1}$ & $2.3 \times 10^{1}$ & $3.1 \times 10^{0}$ & $2.5 \times 10^{2}$ \\
\hline In Utero, 3rd tri. & $1.3 \times 10^{2}$ & $2.1 \times 10^{0}$ & $3.8 \times 10^{2}$ & $4.4 \times 10^{0}$ & $8.4 \times 10^{1}$ & $7.2 \times 10^{1}$ & $7.8 \times 10^{0}$ & $6.8 \times 10^{2}$ \\
\hline
\end{tabular}

$\begin{array}{lllllllll}\text { Adult Male } & 6.7 \times 10^{1} & 2.0 \times 10^{0} & 1.5 \times 10^{2} & 1.6 \times 10^{0} & 2.8 \times 10^{1} & 2.9 \times 10^{1} & 3.8 \times 10^{0} & 2.8 \times 10^{2} \\ \text { Adult Female } & 6.7 \times 10^{1} & 2.3 \times 10^{0} & 1.6 \times 10^{2} & 1.5 \times 10^{0} & 2.9 \times 10^{1} & 3.0 \times 10^{1} & 4.0 \times 10^{0} & 2.9 \times 10^{2} \\ \text { 14 Year Old } & 9.9 \times 10^{1} & 2.6 \times 10^{0} & 2.2 \times 10^{2} & 2.2 \times 10^{0} & 4.0 \times 10^{1} & 4.2 \times 10^{1} & 5.8 \times 10^{0} & 4.1 \times 10^{2} \\ \text { 12 Year Old } & 1.1 \times 10^{2} & 3.1 \times 10^{0} & 2.4 \times 10^{2} & 2.4 \times 10^{0} & 4.4 \times 10^{1} & 4.5 \times 10^{1} & 5.9 \times 10^{0} & 4.5 \times 10^{2} \\ \text { 9 Year Old } & 1.3 \times 10^{2} & 4.0 \times 10^{0} & 2.9 \times 10^{0} & 2.9 \times 10^{0} & 4.9 \times 10^{1} & 5.3 \times 10^{1} & 6.9 \times 10^{0} & 5.4 \times 10^{2} \\ \text { 6 Year Old } & 1.5 \times 10^{2} & 5.2 \times 10^{0} & 3.5 \times 10^{2} & 3.5 \times 10^{0} & 5.8 \times 10^{1} & 6.3 \times 10^{1} & 7.7 \times 10^{0} & 6.4 \times 10^{2} \\ \text { 1 Year Old } & 3.3 \times 10^{2} & 1.1 \times 10^{1} & 7.1 \times 10^{2} & 7.4 \times 10^{0} & 1.2 \times 10^{2} & 1.4 \times 10^{2} & 1.7 \times 10^{1} & 1.3 \times 10^{3} \\ \text { In Utero, 2nd tri. } & 1.2 \times 10^{2} & 3.4 \times 10^{0} & 2.7 \times 10^{2} & 2.2 \times 10^{0} & 4.3 \times 10^{1} & 4.4 \times 10^{1} & 6.1 \times 10^{0} & 4.9 \times 10^{2}\end{array}$

Utirik Island, rad

$\begin{array}{lllllllll}\text { Adult Male } & 7.8 \times 10^{0} & - & 8.3 \times 10^{1} & 1.4 \times 10^{0} & 3.2 \times 10^{1} & 2.4 \times 10^{1} & 2.7 \times 10^{0} & 1.5 \times 10^{2} \\ \text { Adult Female } & 8.0 \times 10^{0} & - & 8.7 \times 10^{1} & 1.5 \times 10^{0} & 3.4 \times 10^{1} & 2.4 \times 10^{1} & 2.7 \times 10^{0} & 1.6 \times 10^{2} \\ \text { 14 Year Old } & 1.2 \times 10^{1} & - & 1.2 \times 10^{2} & 2.1 \times 10^{0} & 4.8 \times 10^{1} & 3.5 \times 10^{1} & 3.8 \times 10^{0} & 2.2 \times 10^{2} \\ \text { 12 Year Old } & 1.2 \times 10^{1} & - & 1.3 \times 10^{2} & 2.3 \times 10^{0} & 5.2 \times 10^{1} & 3.8 \times 10^{1} & 4.0 \times 10^{0} & 2.4 \times 10^{2} \\ \text { 9 Year Old } & 1.6 \times 10^{1} & - & 1.7 \times 10^{2} & 2.8 \times 10^{0} & 5.7 \times 10^{1} & 4.5 \times 10^{1} & 4.7 \times 10^{0} & 3.0 \times 10^{2} \\ \text { 6 Year Old } & 1.8 \times 10^{1} & - & 1.9 \times 10^{2} & 3.2 \times 10^{0} & 6.7 \times 10^{1} & 5.2 \times 10^{1} & 5.5 \times 10^{0} & 3.4 \times 10^{2} \\ \text { 1 Year Old } & 3.9 \times 10^{1} & - & 3.7 \times 10^{2} & 6.6 \times 10^{2} & 1.4 \times 10^{2} & 1.1 \times 10^{2} & 1.1 \times 10^{1} & 6.6 \times 10^{2} \\ \text { Newborn } & 1.9 \times 10^{0} & - & 2.8 \times 10^{1} & 4.3 \times 10^{-1} & 9.8 \times 10^{0} & 7.7 \times 10^{0} & 2.0 \times 10^{-1} & 4.8 \times 10^{1} \\ \text { In Utero, 3rd tri. } & 5.0 \times 10^{0} & - & 5.6 \times 10^{1} & 3.9 \times 10^{-1} & 2.0 \times 10^{1} & 1.5 \times 10^{1} & 1.5 \times 10^{0} & 9.8 \times 10^{1} \\ \text { In Utero, 2nd tri. } & 1.4 \times 10^{1} & - & 1.5 \times 10^{2} & 2.2 \times 10^{0} & 5.0 \times 10^{1} & 3.6 \times 10^{1} & 4.1 \times 10^{0} & 2.6 \times 10^{2}\end{array}$

*Multiply by 0.01 to obtain gray. 
BRAVO fallout: Surface and airborne activity, fallout granule size, and exposure rate at any time after the detonation were developed for 142 nuclides at Rongelap and Utirik on the basis of the reported nuclide composition on day 26 postdetonation. Over 70 documents were reviewed for information regarding exposure-rate readings, film-badge readings, fallout composition, dose and dose rate, body burdens, urine analyses, gastrointestinal tract contents, bone marrow and thyroid dose estimates, and activity measurements in soil, water, marine life, and land animals. Results from the meteorology study and archival soil study were also reexamined and compared to fallout composition results. ${ }^{1}$

A tabulation of the estimates of thyroidabsorbed dose, age at exposure, and specific nuclides is given as Table 1 . The thyroid- absorbed dose from iodine and tellurium nuclides was 7.7 times greater than the absorbed dose due to ${ }^{131} I$ at Rongelap for an adult male. It was 10 times greater than the absorbed dose due to ${ }^{131} \mathrm{I}$ at Sifo Island and 4.7 times the absorbed dose due to ${ }^{131}$ I at Utirik Island. James assumed the total thyroid absorbed dose was 2.6 times greater than the absorbed dose due to ${ }^{131} \mathrm{I}{ }^{3}$ The factor 2.6 would be appropriate for slightly older fallout than that experienced at Rongelap, Utirik, or Sifo Islands. Table 1 was based on ingestion intake. Inhalation intake and absorption through skin could not be reconciled with measurements of ${ }^{131} \mathrm{I}$ in urine or with external exposure rate measurements.

The average and maximum estimates of total thyroid-absorbed dose were tabulated in Table 2. Observations of the range of ${ }^{137} \mathrm{Cs}$ body burdens during protacted exposure ${ }^{7}$ and the

Table 2

Total Thyroid-Absorbed Dose Estimate Average Estimate, rad*

\begin{tabular}{|c|c|c|c|c|c|c|c|c|c|}
\hline \multirow[b]{2}{*}{ Age } & \multicolumn{3}{|c|}{ Rongelap Island } & \multicolumn{3}{|c|}{ Sifo Island } & \multicolumn{3}{|c|}{ Utirik Island } \\
\hline & Internal & External & Total & Internal & External & Total & Internal & External & Total \\
\hline Adult Male & 1000 & 190 & 1200 & 200 & 110 & 400 & 150 & 11 & 160 \\
\hline Adult Female & 1100 & 190 & 1300 & 290 & 110 & 410 & 160 & 11 & 170 \\
\hline 14 Year Old & 1400 & 190 & 1600 & 410 & 110 & 530 & 220 & 11 & 230 \\
\hline 12 Year Old & 1600 & 190 & 1800 & 450 & 110 & 570 & 240 & 11 & 250 \\
\hline 9 Year Old & 2000 & 190 & 2200 & 540 & 110 & 660 & 300 & 11 & 310 \\
\hline 6 Year Old & 2400 & 190 & 2600 & 640 & 110 & 760 & 340 & 11 & 350 \\
\hline 1 Year Old & 5000 & 190 & 5200 & 1300 & 110 & 1400 & 670 & 11 & 680 \\
\hline Newborn & 250 & 190 & 440 & - & - & - & 48 & 11 & 59 \\
\hline In Utero, 3rd tri. & 680 & 190 & 870 & - & - & - & 98 & 11 & 110 \\
\hline \multirow[t]{2}{*}{ In Utero, 2nd tri. } & - & - & - & 490 & 110 & 610 & 260 & 11 & 270 \\
\hline & & & \multicolumn{3}{|c|}{ Maximum Estimate, rad* } & & & & \\
\hline Adult Male & 4000 & 190 & 4200 & 1120 & 110 & $1200^{\circ}$ & 600 & 11 & 610 \\
\hline Adult Female & 4400 & 190 & 4600 & 1160 & 110 & 1300 & 640 & 11 & 650 \\
\hline 14 Year Old & 5600 & 190 & 5800 & 1600 & 110 & 1700 & 880 & 11 & 890 \\
\hline 12 Year Old & 6400 & 190 & 6600 & 1800 & 110 & 1900 & 960 & 11 & 970 \\
\hline 9 Year Old & 8000 & 190 & 8200 & 2200 & 110 & 2300 & 1200 & 11 & 1200 \\
\hline 6 Year Old & 9600 & 190 & 9800 & 2600 & 110 & 2700 & 1400 & 11 & 1400 \\
\hline 1 Year Old & 20000 & 190 & 20000 & 5200 & 110 & 5300 & 2700 & 11 & 2700 \\
\hline Newborn & 1000 & 190 & 1200 & - & - & - & 190 & 11 & 200 \\
\hline In Utero, 3rd tri. & 2700 & 190 & 2900 & - & - & - & 390 & 11 & 400 \\
\hline In Utero, 2nd tri. & - & - & - & 2000 & 110 & 2100 & 1000 & 11 & 1000 \\
\hline
\end{tabular}

*Multiply by 0.01 to obtain gray. 
range associated with the contents of the stomach in cases of sudden death ${ }^{8}$ were used to estimate maximum thyroid-absorbed dose. The average dose was based on the average ${ }^{131} I$ activity in urine collected from people exposed at Rongelap Island. The contribution to thyroid dose from external sources was estimated by us frorn the air exposure created by 142 nuclides estimated from results of fallout composition. The external dose estimated by us was similar to original estimates by Sondhaus for persons exposed at Rongelap and Utirik Islands. The original external dose estimates at these islands, 1.75 gray and 0.14 gray (175 rad and $4 \mathrm{rad}$ ), respectively, were derived from survey instrument readings taken at evacuation and film badge data from a nearby military outpost. ${ }^{9} \mathrm{Our}$ external dose value at Sifo Island, 1.1 gray (110 rad), was greater than the 0.69 gray (69 rad) originally estimated by Sondhaus from postevacuation surveys of exposure rate. The difference was due to the presence of very short-lived activation and transuranic nuclides which, according to the nuclide composition, must have been present prior to evacuation of Sifo Island.

Medical observations concerning thyroid abnormalities have been tabulated by us along with the new thyroid dose. From these results, we estimate the mean cancer risk rate in the exposed population of 251 people to be 150 thyroid cancers per million-person gray years at risk (1.5 \pm 2.5 thyroid cancers per million-person rad years at risk). The mean time at risk for thyroid cancer was 19 years. We estimated the mean thyroid nodule risk rate to be 830 nodules per milliun-person gray years at risk $(8.30 \pm 14$ per million-person rad years at risk). The mean time at risk for a thyroid nodule was 18 years. The uncertainty derived for the estimate of risk was based on the standard deviation in adult mean urine activity concentration, the standard deviation in thyroid-absorbed dose per unit intake, and the standard deviation in the spontaneous frequency of thyroid nodules or lesions in the unexposed comparison group.

\section{Acknowlecigments}

The reexamination was accomplished because of the fine efforts of Dr. Fred Brauer of Battelle Pacific Northwest Laboratory, Dr.
Kendall Peterson of Lawrence Livermore National Laboratory, Dr. Charles Sondhaus of the University of California, William Adams, M.D., Dr. John Baum, Victor Bond, M.D., Donald Borg, M.D., Robert Conard, M.D., Eugene Cronkite, M.D., Andrew Hull, Edward Lessard, Charles Meinhold, Robert Miltenberger, Stephen Musolino, and Dr. Jan Naidu, all from Brookhaven National Laboratory, Nathanial Greenhouse from Lawrence Berkeley Laboratory, Dr. Bruce Wachholz from the National Cancer Institute, Thomas McCraw and Roger Ray from the Department of Energy, and Barbara Boccia, M.D., a physician in private practice.

\section{References}

1. Lessard, E.T., Miltenberger, R.P., MusoLiNo, S.V., NaIDU, J.R., AND CoNard, R.A., Thyroid-Absorbed Dose for Rongelap and Utirik Residents. BNL, in press.

2. Cronkite, E.P., Bond, V.P., and Dunham, C.L., (Eds.), Some Effects of Ionizing Radiation on Human Beings. United States Atomic Energy Commission Report, Washington, DC, 1956.

3. James, R.A., Estimate of Radiation Dose to Thyroid of Rongelap Children Following the BRAVO Event, UCRL-12273, 1964.

4. Conard, R.A. ET AL., A Twenty-Year Review of Medical Findings in a Marshallese Population Accidentally Exposed to Radioactive Fallout, BNL 50424, 1974.

5. Committee on the Biological Effects of Ionizing Radiation. The Effects on Populations of Exposure to Low Levels of Ionizing Radiation, National Research Council Report, National Academy Press, Washington, DC, 1980.

6. Lessard, E.T. Miltenderger, R.P., Cohn, S.H., Musolino, S.V., and Conard, R.A., Protracted exposure to fallout, the Rongelap and Utirik experience, Health Phys. 46, 511-27 (1984).

7. Miltenderger, R.P., Greenhouse, N.A., AND LESSARD, E.T., Whole body counting results from 1974 to 1979 for Bikini Island Residents, Health Phys. 39 (3), 395-408 (1979).

8. Eve, I.S., A review of the physiology of the gastrointestinal tract in relation to radiation doses from radioactive materials, Health Phys. 12, 131-61 (1966).

9. Sondhaus, C.A. ANd Bond, V.P., Physical Factors and Dosimetry in the Marshall Islands Radiation Exposures, Naval Medical Research Institute Report, Bethesda, MD, WT-939, 1955. 


\section{APPENDIX I}

Prepared by Edward T. Lessard, Manager, Marshall Islands Radiological Safety Program and Internal Dosimetry, Safety and Environmental Protection Division, Brookhaven National Laboratory. 


\section{APPENDIX \|}

Hospital summary from the Clincial Center, the National Institutes of Health, Bethesda, Maryland, on Patient No. 2160X who underwent surgical removal of a pituitary tumor in 1982. 
Admitted on 8-23-82

\section{CHIEF COMPLAINT:}

Followup evaluation.

\section{UISTORY OF PRESENT ILLNESS:}

obtained from the charts and with translater. This is the second NIH admission for this 29-year-old female from the Marshall Islands. She was initially evaluated for amenorrhea and galactorrhea and serum prolactin levels are 400 to $600 \mathrm{ng} / \mathrm{ml}$.

The patient was living on the larger island of Ebeye when doctors working on the Marshall Islands found an elevated prolactin level. At that time her main complaint. was amenorrhea. She states that her growth and development had been normal. She had menarche at age 13 . Her menses were regular and then suddenly stopped in 1969 and she only had occasional spotting. In 1974 , she developed galactorrhea which has persisted. Her only other complatit was headache without any visual changes.

She was fintielly worked up at the Brookhaven National Laboratory. Her cesting included a chest $x-r a y$ which was normal, a negative pregnancy test, a negactve RPR, a serum proteln electrophoresis which was normal, visual acuity which was normal, triglyceride level of 227 , and increased white blood count of 11,600 and increased platelet count of 465,000. She had abnormal liver function tests, with SGOT of 83 , and SGPT 123, and alkaline phosphatase of 1ng. Stools were positive for whipworm. She had a uric acid of 8.3, normal thyroid function tests, and trace protein in her urine.

She was then sent to the NIA for more extensive evaluation. She had a careiul pelvic examination which was entirely normal. Sella $x$-rays showed an enlarged sella with ballooning anterforly. A CT sean of the head showed a $1.2 \mathrm{~cm}$. mass in the antertor sella and sightly to the left.t The mass enhanced wich contrast. There was no suprasellar extension. Visual fields were normal at that time. Her serum prolactin levels were 500 to $650 \mathrm{ng} i$ inl. DHAS was $326 \mathrm{meg} / \mathrm{d} 1$. cortisoj. was $8.1 \mathrm{mcg} / \mathrm{dl}$.. 17-hydroxysteroids were $4.0 \mathrm{mg} .124$ hours. Her T3 was 128 , TSH $3.4, \cdot$ TBG was 33 , T4 9.6 and free T4 was 1.4. She had an ACTH stimulation test. Her baseline cortisol was $6.6 \mathrm{mcg} / \mathrm{d} 1$. After ACTH at 30 minutes the cortisol rose to $26 \mathrm{mcg} / \mathrm{dl}$. and at ho minutes it was $26 \mathrm{mcg} / \mathrm{dl}$. She had a TRH stimulation test and the values of $\dot{T} S H$ at -15 minutes was 1.1 ; at 0 it was 0.6 ; after the TRF it was at 20 minutes 4.9 ; at 30 minutes 5.8 ; and at 60 minutes 3.5 . She had an SGOT of 71 and SGPT 139, and alkaline phosphatase 82, and bilirubin 0.8. She had a normal abdominal echo. She had a liver-spleen scan which was normal. Her hepatitis burface antigen was negative. Ceruloplasmin was $290 \mathrm{mg} / 1$. ller

Adnitted on $8-23-82$

Qperation Report (OPN)

Mistory and Physieal Examination (HPE)

[] Dischorge Summory (DS) DS Combined with HPE Interim Summary (IS) IS Combined with HPE Addendum Summary (AS)

THE CLIHICAL CENTER 
ANA was less than 20. Alpha antitrypsin level was $230 \mathrm{mg} / \mathrm{dl}$. White blood count was 8,000 , and hematocric was 44 , platelet count was 377,000 . Uric acid was 9, triglycerides 177, and cholesterol 238. Urinalysis was negative. She had stools for ova and parastes which were positive. She vas seen by the Liver Service who felt that her abnormal liver function tests were related to a mild chronic hepatitis. There was no clear etiology. Hematology felt that her $C B C$ should be followed and there was no need for a bone marrow at this time. Infectious Disease felt the parasitology in the scool was nild with no therapy, and did not feel that that accounced for her abnormal liver function tests.

The patient returns now for followup evaluation and consideration for surgery for her adenoma. At the present time she still has galactorrhea and amenorrhea. She has had unprotected intercourse for several years withour pregnancy. She has noted no spotting. She still has bicemporal headaches about once a week. There ts no nausea, vomiting, visual changes but occasionally has some diziness. She dentes any change in her peripheral vision, salt-craving, orthostasis, syncope, fever, chills, night sweats, increased thirst or polyuria, cold or heat intolerance, decreased appetice or weight loss. There is no nausea or vomfting. She occasionally has diarthea, sometimes four to five stools per day, the last episode was a week before admission. She has had this problem over several years. There is no increased sweating or paresthesias.

PAST HISTORY:

No surgeries or serlous medical illnesses.

Medications: None at the present time.

Allergies: None known.

FAMILY HISTORY:

Father with dlabetes; other family members are all alive and well. SOCIAL HISTORY:

She is a housewife, born on the island of Utrik, in the Pacific Ocean. she has moved and lived on the isle of Ebeye since 1962. She 1s married and has recently adopted one son. There is no history of alcohol and she is as non-smoker.

PHYSICAI. EXAMINATION:

Vital Signs: Blood pressure $115 / 90$, pulse 88 and regular, while she was

Admitted on 8-23-82

Oparation Report (OPN)

Xistory and Physical Exomination (HPE)

Dischorge Summary (DS)

DS Combinod with HPE

Interim Summory (IS)

Is Combined with HPE

$-2-$

Addendum Summary (AS) 
lying; blood pressure was 110/75, pulse 90 and regular when sitting; and blood pressure went to $95 / 70$ and pulse 100 , when the patient stood up. Respiratory rate was 16 and she was afebrile.

Ceneral: She is a wel1-developed, well-nourished female in no acute distress, has a very rounded facies. Skin was warm and dry. Skin on the feet very coarse. There were a few scars on the lower extremities bilateraliy. She has supraclavicular fat pads but no buffalo hump. Skin is also darkened and coarse around the neck and in the axillae.

Head, Eyes, Ears, Nose and Throat: Normocephalic. There were no nodes. Pupils were equal, round and reactive to light. Extraocular movements were full. There was no nystagmus. Discs were sharp. Visual fields were within normal limits to direct confrontation. Tympanic membranes were clear. Throat was clear, uvula midline. Inferior turbinates were normal.

Neck: Supple. There were no nodes. Trachea was midline. There was no palpable thyroid nodules or enlargement of the gland. Carotids were $2+$ bilaterally without bruits.

Back: No CVA tenderness.

Breasts: Small, symmetrical. Nipple was inverted on the right. There were no masses and I was not able to express any milk on examination. There were no axillary nodes. She had normal axillary hatr.

Cardiac: TMI was in the 5 th intercostal space, midclavicular line. Both $S 1$ and $S 2$ were normal. There were no murmurs or gallops.

Lungs: clear to auscultation and percussion.

Abdomen: Soft, and non-tender with good torie. There was no organomegaly or masses. There were no brults' appreciated.

Extremities: No clubling, cyanosis or edema. All pulses were 2+ bilaterally.

Neurologic: Cranial nerves II through XII were intact. Motor examination was normal for both upper and lower extremfties. Cerebellar function was thought to be intact. There was no Romberg. She had normal senution to vibration and light touch. Deep tendon reflexes were 2 t in the upper extremities, $1+a t$ the knees, trace at the ankles and there bere no Babinskis.

Genttalia: There is normal female publc hair, Tanner stage $v$, normal external genitalia. 
Admitted on 8-23-82

Discharged on $9-24-82$

\section{SIGNIFICANT FINDINGS :}

Laboratory: Her glucose was 99, sodium 140, potassium 4.0, choride 102 , bicarbonate 23, calcium 5.2, phosphorus 4.5, BUN 12 , creatinine 0.9 , uric acid 7.9, total blirubin was 0.4 , alkaline phosphatase was 113 , lDH was 178, SGPT 61, SGOT 30, GGTP was 50, CPK 83, cholesterol 209. Her total T, was 7.7, free $T_{4}$ was 1.6 and $T$ sh was 4.9. Her white blood count was 10,500 , hemoglobin 14.9 , hematocrit. 42 , differential count on that was 36 polys, 1 eosinophil, 5 basophtis, 55 lymphocytes and 3 monocytes. Her platelet count was 354,000. She had an ACTH gtimulation test before the surgery. Her baseline was 24.4 mcg. per dectliter; at 30 minutes she was 30.9 mcg. per deciliter and at 60 minutes she was 33.5 mcg. per deciliter. She also had an ITT before surgery and the results of that for the glucose at -15 , glucose was 85 at 0 , it was also 85 at 20 minutes, It was 69 at 30 minutes, it was 62 at 45 minutes, it was 64 at 60 minutes, and at 90 minutes it was 88 . Her corresponding cortisols were at -158.8 , at 06.6 , at 20 minutes 10.6 , at 30 minutes 12.5 , at 45 minutes 21.2 , at 60 minutes 30.6 and at 90 minutes 28.4 . She essentialiy recelved 0.1 units of insulin per $\mathrm{kg}$. and got a dose of 6.8 units of Insulin for her ITT. Her urinalysis, except for small amounts of hemoglobin with some white celis, and a few red celis, a repeat of that showed no red blood cells or white blood cells and oniy a small amount of hetioglobin. SHe had an electrocardiogram which was normal.

$x$-rays: Her chest $x$-ray showed no active lung disease. THere was no pulmonary inflitrates or nodules seen. She had a repeac scan of her sella and the impression was a pltuitary microadenoma, predominanty left sided. THere was no extension into the suprasella cistern or invasion to the left cavernous sinus.

The patient was seen in consultation by Neurosurgery and it was decided f.n terms of her living on the Marshall Islands that the best form of therapy for her hyperprolactinoma was to have a surgical resection.

\section{COURSE IN HOSPITAL:}

The patient was taken to the operating room on September 1,1982 and she had a transsphenoldal removal of her intrasellar tumor. A soft tissue tumor which was moderately gritty and firm in consistency and was composed of multiple very small cysts with a yellowish white translucent color was encountered. THe leison was thought to lie in the left two thirds of the patient's sella and had displaced the normal appearing pituitary gland to the right and inferiorly. During the removal of the lesion it was apparent that the tumor was adherent to the superfor aspect of the sella and that $1 t$

Admited on 8-23-82

Discharged on 9-24-82
Operation Report (OPN)

History and Physical Examinotion (HPE)

$\nabla$ Discharge Summary (DS)

DS Combined with HPE

Interim Summory (IS)

IS Combined with HPE

Addendum Summary (AS) 
surrounded the upper Intrasellar portion of the pltultary $\varepsilon$ ialk. There ias no other evidence of tumor within the gland and it was felt that this may have been the cause of the patient's hypoprolactinemia. Following surgery, the patient had a rather uneventful course except for development of a persistent CSF leak. SHe was then brought back down to the Neurosurglcal Service on Septmber 8 and had an lndweling subarachnold drainage catheter placed for three to four days via a lumbar puncture. The results of the CSF that was obtalned at that time; there were two white blood cells, 200 red blood cells, her glucose was 78 and her protein was 34 . The patient remalned on dralnage for five days and after removal of the drain, had no further CSF or rhinorrhea. She has remalned afebrile without any postoperative complications.

Laboratory data following her surgery - her white blood count was 10,400 , hemoglobin 12.0 , hematocr1t 34 , platelet count 408,000, sod1um 141 , potassium 4.4, chlor1de 100 , blcarbonate 28, BUN 18, creatinine 1.3. Her $T_{3}$ was 125, $T_{4} 9.6$, free $T_{4} 1.7$. ACTH stimulation test after surgery, her 0 time was $8.7,30$ minutes post ACTH her cortisol was 30.8 and at 60 minutes her cortisol was 38.9. It was felt that the patient had had a relatively uncomplicated hospital course and has done well.

\section{OPERATIONS AND DATES PERFORMED:}

As noted the patient underwent a transsphenoldal hypophysectomy on September 1,1982 .

\section{CLINICAL DIAGNOSES:}

1. Hyperprolactinema.

2. Galactorrhea/amenorrhea, secondary to number 1 .

3. Status-post transsphenoldal hypophysectomy.

4. History of abnormal liver function tests. At this time the only abnormality is a silght elevation in her SGPT, all the other numbers have normalized. On return visit here these should be repeated again.

5. Slightly elevated whtte count and platelet count. Agaln, these are only mild ejevations and should just be followed when the patient returns.

6. History of parasites in the stool. Th1s is thought, to not be causing her any chronic debilitation since the patient has no evidence of malabsorption and this is probably secondary to the living situation and on follow-up the patient should just be questioned about persistent diarrhea and whether she would be developing any symptoms of malabsorption. This was felt to be benign when she was seen by Infectious Diseases on her last visit in January of 1982 .

Admitted on 8-23-82

Discharged on $9-24-82$
Operation Report (OPN)

History and Physical Examination (HPE)

$D$ Discharge Summory (DS)

DS Combined with HPE

Interim Summary (IS)

IS Combined with HPE

Addendum Summary (AS) 
CONDITION OF PATIENT:

Stable.

INSTRUCTIONS TO PATIENT AND DISPOSITION:

There are no medications and no physical limitations at this time. The patient will be discharged to home and will come back to the National

Institutes of Health for follow-up in elther six months to one years' time.

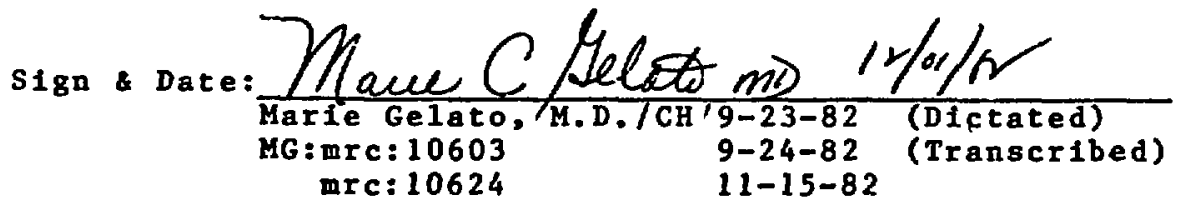

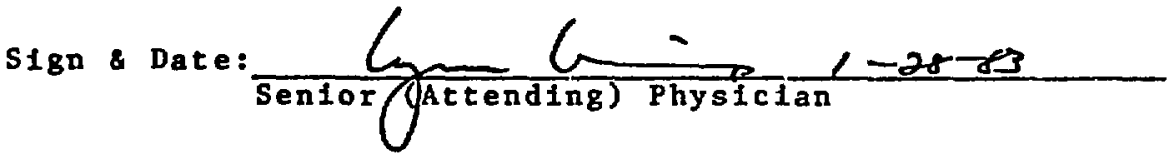

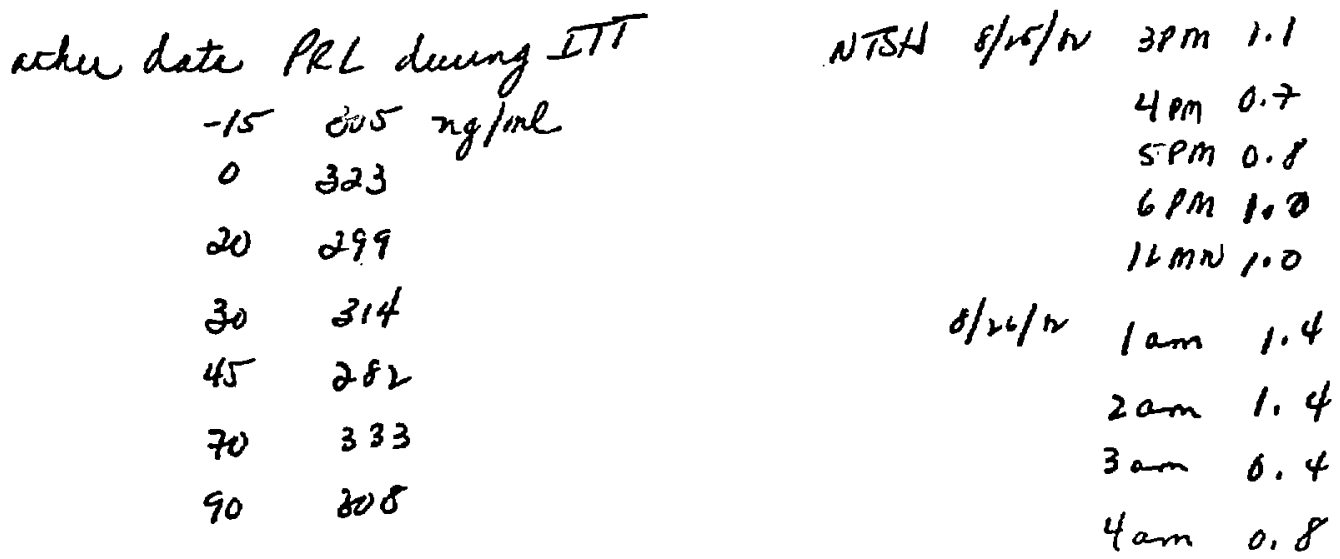

Admitted on $8-23-82$

Discharged on $9-24-82$
Operation Report (OPN)

History and Physical Examination (HPE)

Discharge Summary (DS)

DS Combined with HPE

interim Summary (IS)

is Combined with HPE

Addendum Summary (AS) 


\section{STRAUB CLINIC \& HOSPITAL, INC. honolulu, hawall}

Patient Name

KAAIAKAMANU, TOMO

DATE OF ADMISSION:

DATE OF DISCHARGE:
ROOM NO

ACCORD NO

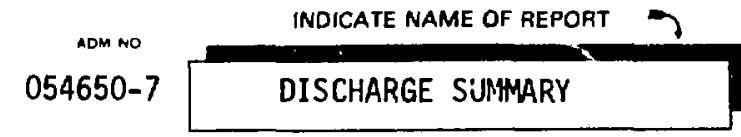

FINAL PRIMARY DIAGNOSIS: MENINGIOMA

FINAL SECONARY DIAGNOSIS: PNEUMONIA

HISTORY OF PRESENT ILLNESS: This is the first Straub Hospitai admission for this 43year-old woman who is a former resident of the Marshall Islands. She reported a febrile illness 3 weeks prior to admission which was followed by bitemporal to generalized throbbing type headache which was progressive and present 24 hours a day unrelieved by aspirin or Tylenol. She also described attacks of hearing noise in her ears followed by dizziness. Her neck had become progressively stiffer and more painful. She described bracing herself against a wall so that her neck would be supported. She has no family history of neurologic disease.

PAST MFDICAL HISTORY: She had had a hysterectomy 10 years prior to admission. No other serious illnesses or accidents or infections.

REVIEW OF SYSTEMS: Negative in detail. She denies allergies. She takes Tylenol as needed for pain. There have been no.psychiatric', G.I., G.U., "endocrine, pulmonary, cardiac or skin problems. She smokes about 1 pack of cigarettes a day. She uses occasional alcohol.

PHYSICAL EXAMINATION: She was an ill-appearing woman. Bo 140/90, heart rate 62; temperature 37. HEENT: Negative for injury otherwise unremarkable. "Neck was held. stiffly. Oropharynx benign. Tinryoid not palpable. Lungs were clear. Breasts without masses or discharge. Heart was regular without significant murmur, rub or gallop. Abdomen was nontender. No organomegaly. Extremities were without edema.: Rectal and pelvic exams were not done.

Neurologic exam showed a somewhat lethargic woman with no decrease in mental status. She appeared to neglect the left side on occasion. Cranial nerves: I) She smelled wintergreen. II) Visual fields were full to confrontation, fundi showed no papilledema. III' IV and VI) Pupils "were $4 \mathrm{~mm}$, reactive to light. V) Corneal response is symietric. VII) No facial weakness. VII-XII) Appear norimal: Motor examination showed no definite hemiparesis. Reflexes were 1-2 throughout.. Patient had questionable bilateral Babinski responses. Sensory and cerebelitar exams were normal. The spine had no areas of tenderness.

Lumbar puncture yielded opening pressure of 210, closing pressure of 180 . Total protein was 103; glucose 65. In tube \#1, there were 4 white celis and in tube \#4 there were 4 white cells: In tube \#1 there were 38 red cells :and in tube \#4 there were 117 red cells. Differential count showed mostly lymphocytes. CT scan showed right hemispheric
lesion.

The patient.was admitted to the hospital and treated with steroids and Manitol with improvement in her symptoma tology.

3 Evaluation subsequently included normal SMA-12 except for elevation in LDH, normal

2 electrolytes. CBC showed hematocrit of 37.2 , white count of 9.7. Normal urinalysis. (CONT INUED) 
Bl seding perimeters were nonmal. VDRL was positive at 0 dilution and FT ABS was also positive: ANA was negative. T4 was 5.3. with RT3U of 43.6, free T4 index was 3.2. which is borderline low. TSH was normal at 3.5. CSF VORL was negative. Chest $x$-ray was normal.: Selective cerebral angiography was done which confirmed a right frontotemporoparietal infiltrating. neoplasm compatible with a glioblastoma: EEG done on 3/23/82 showed excessive slowing in the right hemisphere consistent with a mass effect. An EKG was within normal limits.

The patient underwerit surgery on $3 / 24 / 82$ with complete excision of an angioma: The pathological evaluation revealed some atypical features and other regions were characteristic of angioblastic meningiomas.

The postoperative course was initially unremarkable, but on $4 / 2 / 82$, she became febrile and developed bilateral pneumonia. She was treated initially with Mannitol and Erythromycin with rapid defervesence and improvement in her pulmonary function. She developed bronchospasm treated with inhaled sympathomimetics and Theophylline preparations.

The patient was discharged on $4 / 74 / 82$ in much improved condition. Discharge medication included E-mycin; $250 \mathrm{mg}, 2$ pilis 3 times daily afte meals; Synthroid,' 15 .mg 'daily; phenobarbital, $60 \mathrm{mg} 3$ times a day and Theo-Dur, $300 \mathrm{mg}, 3$ times a day.

The patient had been placed on thyroid suppression because of her previous exposure to radiation in the Marshall Islands.

The patient's positive VORL was treated-with Benzathine penicili in 2.4 million units IM in each buttocks after Beiremid, 1 gram by mouth on the day before discharge: She will be seen in the outpatient clinic in one week where repeat penicillin therapy will be given and again the following week. Hopefully, bronchodilators and Erythromycin can be discontinued at that time. She should remiain on phenobarbital and thyroid replacement indefinitely. She will be seen by myself and Dr. Gonzalo Chong in the outpatient clinic.

JVMY $/ \mathrm{cb}$

Dict: $4 / 19 / 82$

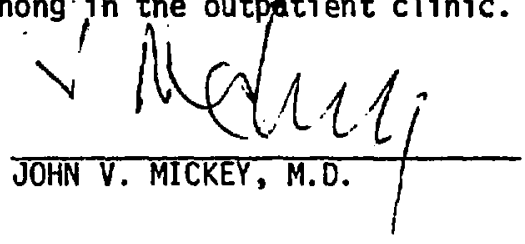

Trans: $4 / 20 / 82$ 


\section{APPENDIX III}

Hospital summary from the Straub Clinic and Hospital, Inc., Honolulu, on Patient No. 2249 who underwent neurosurgery for a meningioma in 1982. 


\begin{abstract}
APPENDIX IV
Individual Marshallese laboratory data collected during the medical surveys of 1981 and 1982.
\end{abstract}

Abbreviations: IDN = Brookhaven National Laboratory identification number; HGB = hemoglobin level in $\mathrm{g} / \mathrm{dl}$; $\mathrm{MCV}=$ Mean corpuscular volume in $\mathrm{fl} ; \mathrm{WBC}=$ leukocyte cous $\mathrm{t} / \mu \mathrm{l}$; $\mathrm{PMN}=$ neutrophil count/ul; BND = band forms/ $\mu \mathrm{i} ; \mathrm{LYM}=$ lymphocytes/ $\mu 1 ;$ MON $=$ monocytes $/ \mu \mathrm{l} ;$ EOS $=$ eosinophils $/ \mu \mathrm{l} ;$ PLT $=$ platelet count $\times 10^{3} / \mu \mathrm{I}$; TSH $=$ thyroid stimulating horinone level in $\mu \mathrm{U} / \mathrm{ml}$; TOX $=$ serum toxoplasina titer (by FIAX) expressed as $\log _{2}$; PRL $=$ serum prolactin in $\mathrm{ng} / \mathrm{ml} ; \mathrm{CAL}=$ serum calcium in $\mathrm{mg} / \mathrm{dl}$; TPR = total serum proteins in $\mathrm{g} / \mathrm{dl} ; \mathrm{ALB}=$ serum albumin in $\mathrm{g} / \mathrm{dl} ; \mathrm{GGL}=$ gamma globulin in $\mathrm{g} / \mathrm{dl}$.

Comments:

1. Identification numbers $1-86$ belong to exposed persons of Rongelap and Ailingnae; numbers beginning at 2102 belong to those of Utirik; numbers from 805 through 1578 belong to the Comparison group.

2. Entries which contain only $9 \mathrm{~s}$ indicate no data were obtained.

3. Most normal ranges of the indicated tests are given in the text. The value of 0.0 for TSH, however, means the level was $<2.5$ $\mu \mathrm{U} / \mathrm{ml}$ (i.e., normal), and the value of 0 for TOX idicates a $\log _{2}$ titer of $<4$. 
COMPUTER LISTING OF 1981 RAW DATA

\begin{tabular}{|c|c|c|c|c|c|c|c|c|c|c|c|}
\hline IDN & HGB & MCV & WBC & PMN & BND & LYM & MON & EOS & BAS & PLT & TSH \\
\hline $\begin{array}{l}1 \\
2 \\
4 \\
5 \\
6 \\
7 \\
8 \\
9 \\
18 \\
12 \\
14 \\
15 \\
16 \\
17 \\
18 \\
19 \\
28 \\
21 \\
22 \\
23 \\
24 \\
27 \\
33 \\
34 \\
35 \\
37 \\
39 \\
46 \\
41 \\
42 \\
44 \\
45 \\
47 \\
48 \\
49 \\
51 \\
53 \\
61 \\
63 \\
64 \\
65 \\
66 \\
67 \\
69 \\
78 \\
71 \\
72 \\
73 \\
74 \\
75 \\
76 \\
77 \\
78 \\
79 \\
84 \\
81 \\
83\end{array}$ & $\begin{array}{l}14.2 \\
15.8 \\
16.1 \\
14.2 \\
14.8 \\
13.4 \\
13.7 \\
15.9 \\
14.9 \\
12.9 \\
13.8 \\
13.8 \\
13.3 \\
13.8 \\
13.1 \\
15.8 \\
16.2 \\
11.1 \\
13.5 \\
15.6 \\
14.6 \\
15.5 \\
12.6 \\
12.3 \\
17.4 \\
14.4 \\
13.5 \\
15.7 \\
14.3 \\
14.3 \\
15.5 \\
12.2 \\
15.7 \\
13.5 \\
15.8 \\
14.3 \\
13.5 \\
15.7 \\
14.1 \\
12.8 \\
18.8 \\
13.3 \\
13.4 \\
11.2 \\
13.3 \\
13.1 \\
13.2 \\
15.4 \\
16.5 \\
13.2 \\
14.8 \\
14.8 \\
13.8 \\
15.8 \\
13.8 \\
12.2 \\
16.2\end{array}$ & $\begin{array}{l}93 \\
96 \\
86 \\
91 \\
93 \\
94 \\
88 \\
95 \\
85 \\
93 \\
96 \\
88 \\
78 \\
87 \\
91 \\
99 \\
86 \\
84 \\
91 \\
97 \\
98 \\
95 \\
82 \\
182 \\
188 \\
95 \\
91 \\
86 \\
94 \\
97 \\
86 \\
95 \\
99 \\
93 \\
98 \\
96 \\
89 \\
88 \\
92 \\
98 \\
79 \\
98 \\
97 \\
999 \\
86 \\
93 \\
83 \\
88 \\
89 \\
93 \\
89 \\
94 \\
97 \\
97 \\
87 \\
92 \\
98\end{array}$ & 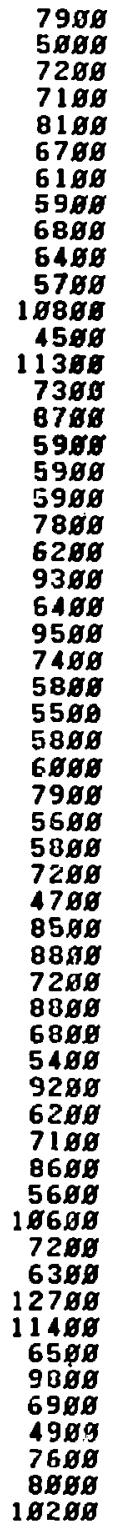 & $\begin{array}{l}4187 \\
2337 \\
2141 \\
3727 \\
4515 \\
4288 \\
3751 \\
3383 \\
4623 \\
3455 \\
2764 \\
4428 \\
2542 \\
7147 \\
4945 \\
5132 \\
3141 \\
3923 \\
2492 \\
3431 \\
2913 \\
4719 \\
3487 \\
6578 \\
4188 \\
2298 \\
2846 \\
2168 \\
2864 \\
4878 \\
2827 \\
2479 \\
4283 \\
2725 \\
3918 \\
6819 \\
4685 \\
4864 \\
2894 \\
2524 \\
3636 \\
2480 \\
3514 \\
99999 \\
3513 \\
5114 \\
4445 \\
4328 \\
6953 \\
6782 \\
2988 \\
7545 \\
4981 \\
2768 \\
5776 \\
5679 \\
5823\end{array}$ & $\begin{array}{r}237 \\
25 \\
18 \\
35 \\
324 \\
16 \\
8 \\
44 \\
51 \\
6 \\
6 \\
27 \\
45 \\
8 \\
36 \\
65 \\
14 \\
8 \\
8 \\
8 \\
8 \\
8 \\
6 \\
198 \\
37 \\
29 \\
27 \\
6 \\
0 \\
19 \\
14 \\
6 \\
90 \\
11 \\
255 \\
110 \\
18 \\
66 \\
34 \\
13 \\
276 \\
15 \\
71 \\
9999 \\
14 \\
265 \\
36 \\
15 \\
31 \\
28 \\
32 \\
24 \\
86 \\
24 \\
20 \\
6\end{array}$ & $\begin{array}{l}2765 \\
1799 \\
4056 \\
2528 \\
1741 \\
1926 \\
1868 \\
2865 \\
1368 \\
2448 \\
2137 \\
4617 \\
1586 \\
2937 \\
1678 \\
2566 \\
1873 \\
1186 \\
2699 \\
3568 \\
2727 \\
3464 \\
2191 \\
1864 \\
2497 \\
1718 \\
1746 \\
2957 \\
2384 \\
2893 \\
1787 \\
2392 \\
1781 \\
1774 \\
3485 \\
1341 \\
2591 \\
4333 \\
3501 \\
2011 \\
1932 \\
3146 \\
2555 \\
9999 \\
1126 \\
3789 \\
2429 \\
1748 \\
3648 \\
3191 \\
2339 \\
1518 \\
2449 \\
1782 \\
1215 \\
1479 \\
3161\end{array}$ & $\begin{array}{l}553 \\
487 \\
197 \\
443 \\
688 \\
381 \\
289 \\
221 \\
526 \\
256 \\
498 \\
729 \\
188 \\
565 \\
318 \\
435 \\
486 \\
457 \\
295 \\
448 \\
216 \\
465 \\
468 \\
237 \\
378 \\
217 \\
357 \\
268 \\
194 \\
632 \\
377 \\
384 \\
385 \\
152 \\
688 \\
197 \\
323 \\
241 \\
254 \\
216 \\
276 \\
387 \\
266 \\
9999 \\
195 \\
185 \\
161 \\
189 \\
381 \\
342 \\
528 \\
392 \\
258 \\
245 \\
152 \\
580 \\
331\end{array}$ & $\begin{array}{r}158 \\
337 \\
864 \\
372 \\
836 \\
251 \\
137 \\
324 \\
286 \\
239 \\
256 \\
972 \\
135 \\
649 \\
328 \\
586 \\
383 \\
383 \\
412 \\
358 \\
340 \\
534 \\
328 \\
664 \\
314 \\
1536 \\
522 \\
428 \\
615 \\
276 \\
657 \\
688 \\
728 \\
35 \\
178 \\
329 \\
188 \\
118 \\
264 \\
334 \\
3772 \\
1683 \\
178 \\
698 \\
9999 \\
759 \\
755 \\
1325 \\
125 \\
126 \\
2285 \\
1625 \\
698 \\
318 \\
86 \\
156\end{array}$ & 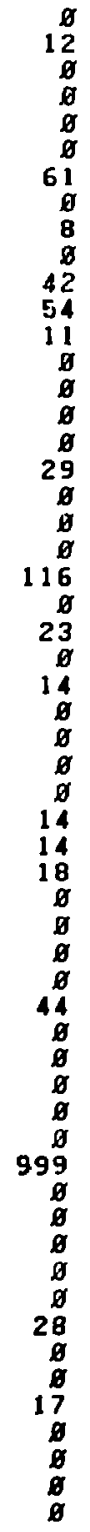 & $\begin{array}{l}245 \\
224 \\
155 \\
288 \\
252 \\
278 \\
264 \\
218 \\
278 \\
999 \\
277 \\
294 \\
254 \\
222 \\
268 \\
175 \\
214 \\
177 \\
387 \\
231 \\
198 \\
265 \\
228 \\
208 \\
386 \\
197 \\
365 \\
198 \\
287 \\
198 \\
281 \\
263 \\
215 \\
276 \\
198 \\
424 \\
381 \\
231 \\
264 \\
264 \\
146 \\
276 \\
275 \\
177 \\
221 \\
346 \\
324 \\
224 \\
255 \\
383 \\
241 \\
264 \\
264 \\
126 \\
223 \\
263 \\
228\end{array}$ & 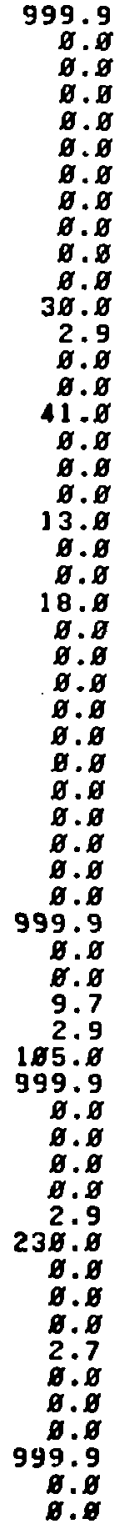 \\
\hline
\end{tabular}




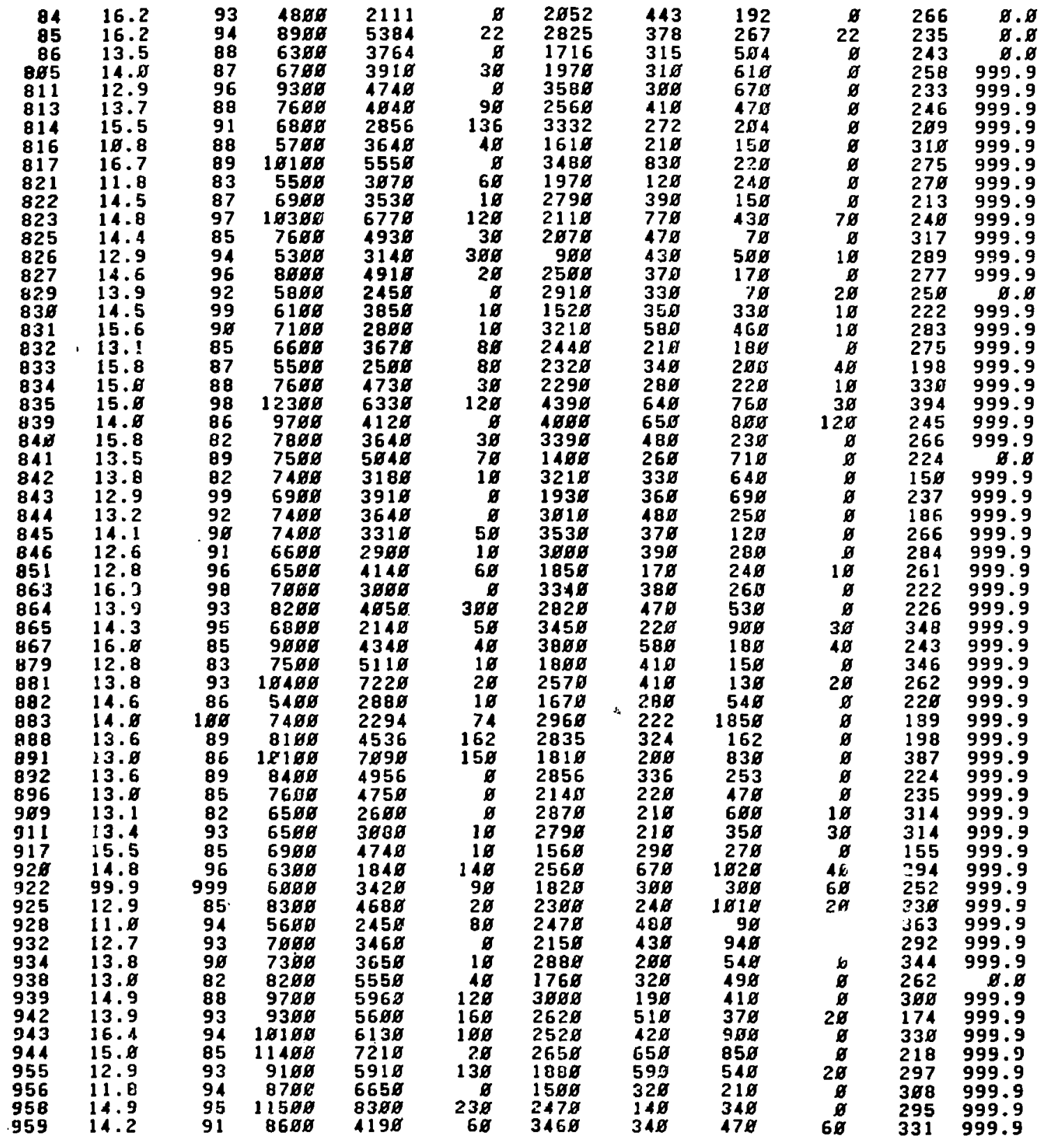


Page 3

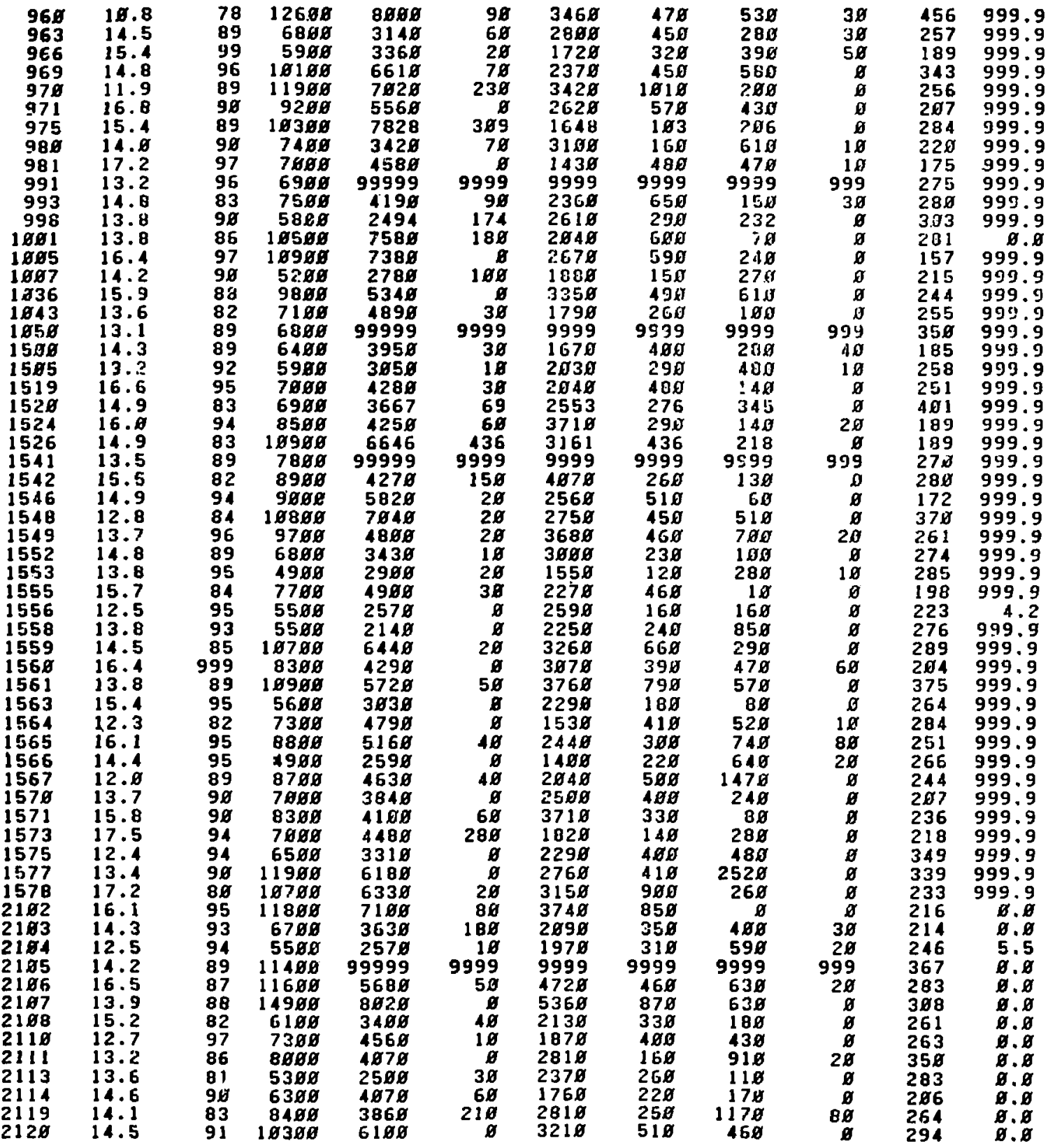




\begin{tabular}{|c|c|c|c|c|c|c|c|c|c|c|c|}
\hline $\begin{array}{l}2123 \\
2124 \\
2125 \\
2126 \\
2128 \\
2129 \\
2138 \\
2132 \\
2134 \\
2136 \\
2137 \\
2138 \\
2139 \\
2142 \\
2143 \\
2114 \\
2145 \\
2148 \\
2119 \\
2158 \\
2152 \\
2153 \\
2155 \\
2156 \\
2157 \\
2158 \\
2159 \\
2168 \\
2162 \\
2164 \\
2166 \\
2167 \\
2168 \\
2172 \\
2174 \\
2176 \\
2179 \\
2182 \\
2185 \\
2188 \\
2189 \\
2193 \\
2194 \\
2195 \\
2196 \\
2197 \\
2288 \\
2285 \\
2286 \\
2287 \\
2288 \\
2289 \\
2218 \\
2212 \\
2213 \\
2215 \\
2216 \\
2217 \\
2218 \\
2228 \\
2211 \\
\end{array}$ & $\begin{array}{l}13.9 \\
16.8 \\
14.8 \\
12.4 \\
11.5 \\
13.5 \\
12.1 \\
14.8 \\
12.7 \\
15.8 \\
14.8 \\
12.8 \\
12.9 \\
16.8 \\
14.9 \\
17.8 \\
13.5 \\
11.3 \\
11.9 \\
16.1 \\
14.7 \\
13.1 \\
99.9 \\
17.1 \\
14.8 \\
13.8 \\
12.6 \\
13.7 \\
11.6 \\
12.4 \\
13.3 \\
15.7 \\
15.1 \\
13.9 \\
16.1 \\
15.4 \\
17.3 \\
12.6 \\
14.9 \\
16.3 \\
14.3 \\
13.2 \\
18.7 \\
12.5 \\
14.2 \\
11.9 \\
13.11 \\
14.6 \\
15.8 \\
16.6 \\
16.5 \\
12.5 \\
13.8 \\
13.1 \\
12.5 \\
14.2 \\
14.8 \\
13.7 \\
15.3 \\
14.1 \\
13.8\end{array}$ & $\begin{array}{r}95 \\
91 \\
96 \\
86 \\
80 \\
81 \\
91 \\
83 \\
89 \\
95 \\
93 \\
91 \\
93 \\
97 \\
84 \\
99 \\
98 \\
93 \\
93 \\
86 \\
94 \\
79 \\
999 \\
94 \\
93 \\
98 \\
98 \\
98 \\
85 \\
92 \\
94 \\
96 \\
180 \\
98 \\
88 \\
94 \\
88 \\
92 \\
180 \\
92 \\
88 \\
90 \\
85 \\
84 \\
88 \\
85 \\
95 \\
89 \\
87 \\
85 \\
89 \\
87 \\
91 \\
93 \\
89 \\
84 \\
87 \\
92 \\
88 \\
91 \\
94\end{array}$ & 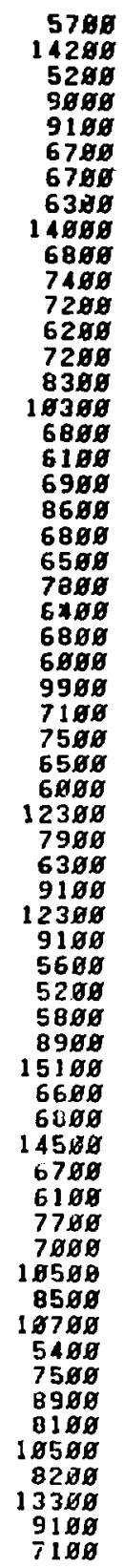 & 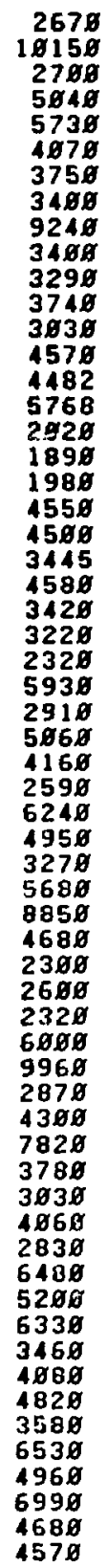 & 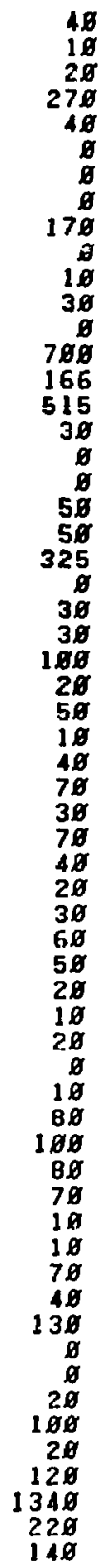 & 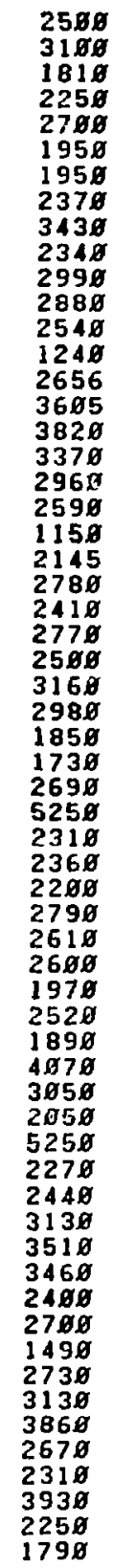 & 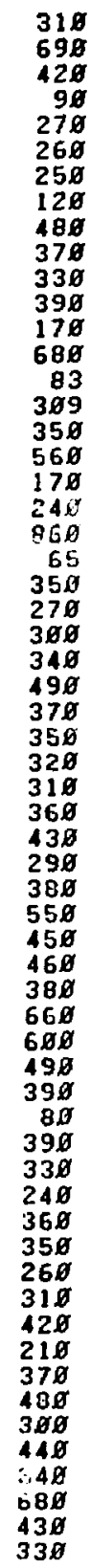 & 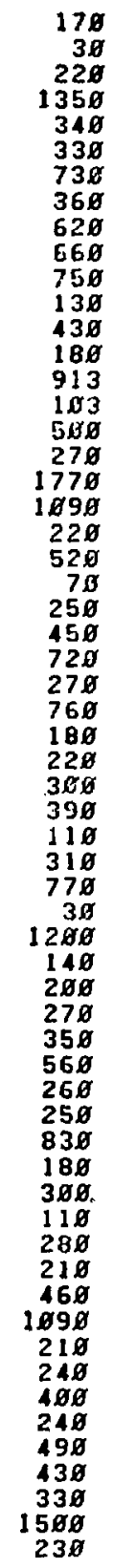 & 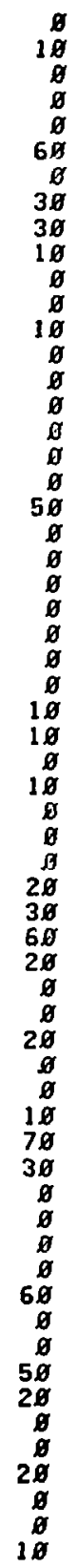 & $\begin{array}{l}197 \\
239 \\
282 \\
287 \\
236 \\
381 \\
235 \\
312 \\
291 \\
289 \\
149 \\
315 \\
369 \\
175 \\
241 \\
249 \\
333 \\
173 \\
272 \\
247 \\
325 \\
308 \\
259 \\
215 \\
332 \\
284 \\
343 \\
383 \\
256 \\
236 \\
280 \\
245 \\
244 \\
253 \\
291 \\
279 \\
236 \\
255 \\
220 \\
222 \\
385 \\
242 \\
269 \\
295 \\
372 \\
267 \\
252 \\
264 \\
249 \\
294 \\
224 \\
393 \\
295 \\
234 \\
368 \\
311 \\
378 \\
297 \\
235 \\
242 \\
245\end{array}$ & 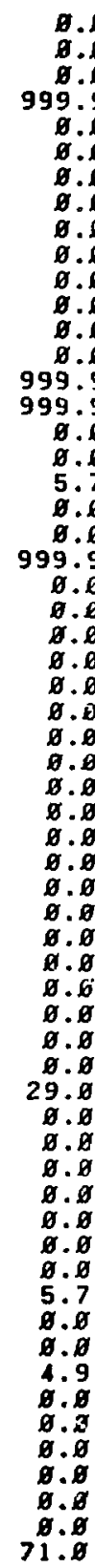 \\
\hline
\end{tabular}




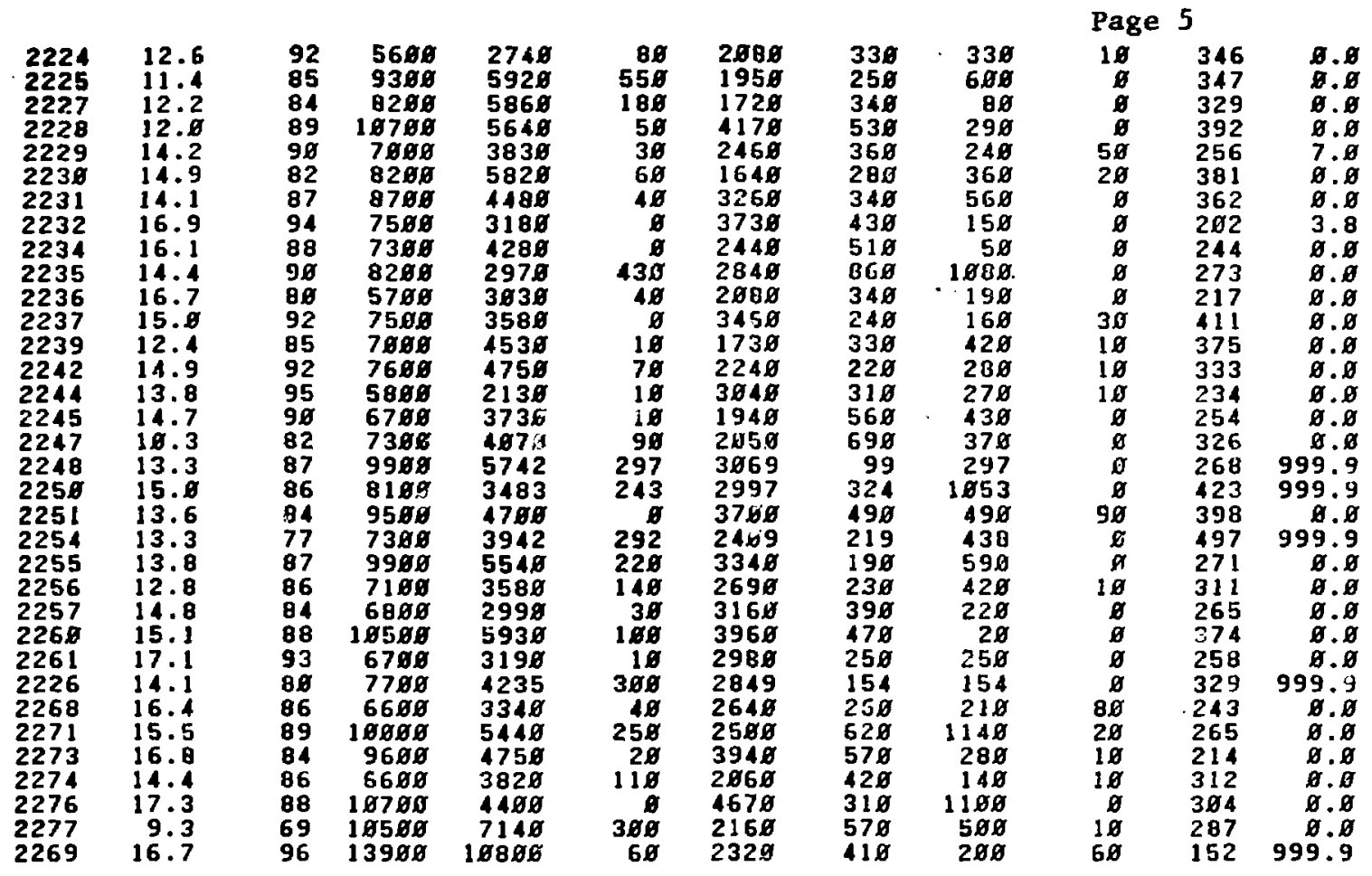




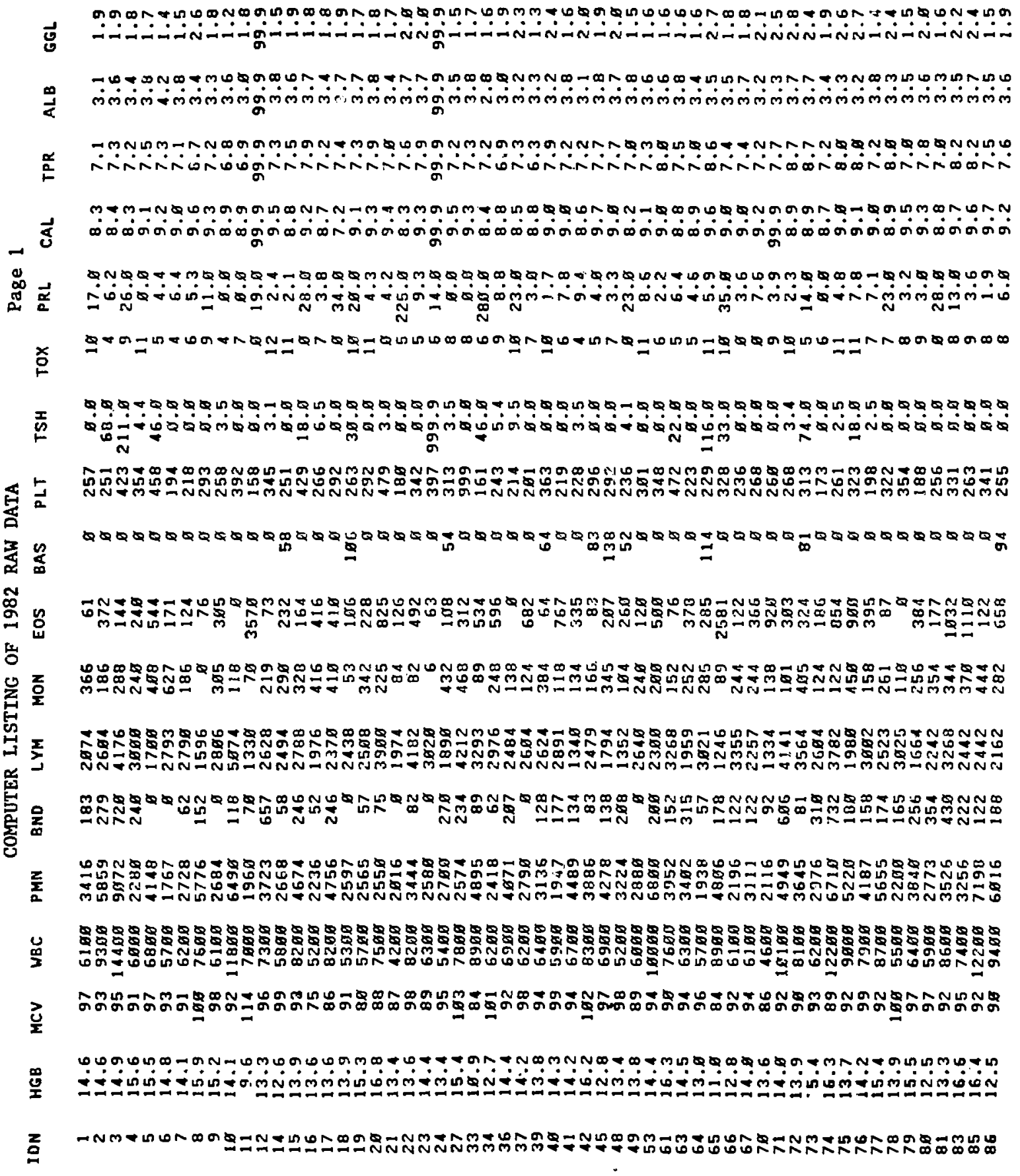

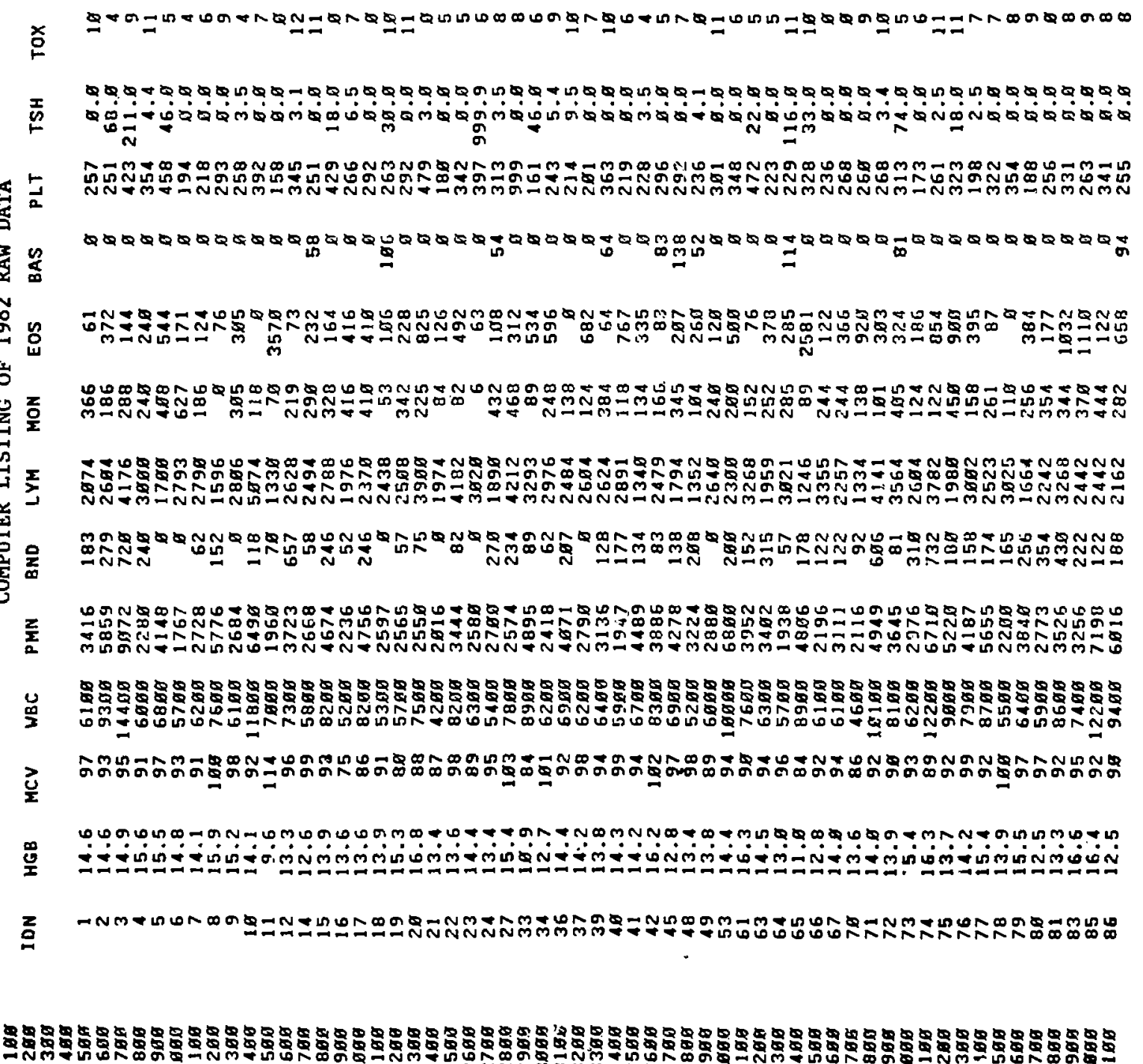

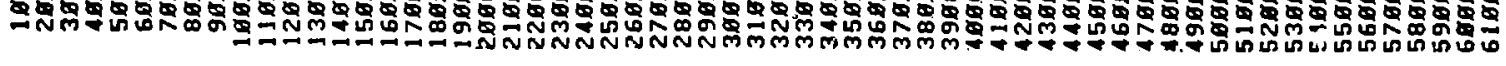




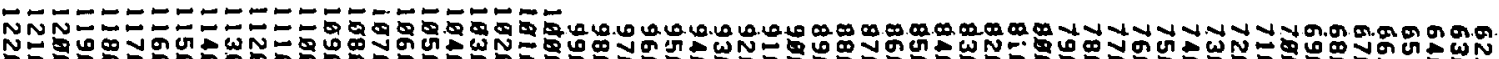

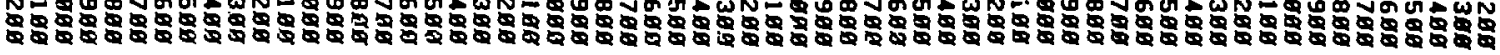

ம

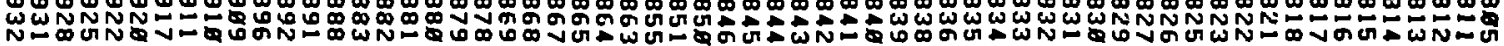

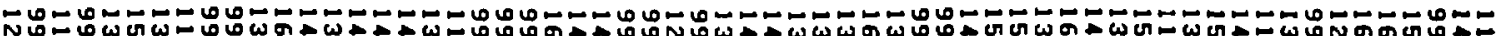
Q م备 (1)

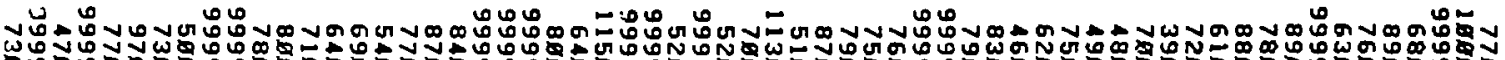
W. wơ

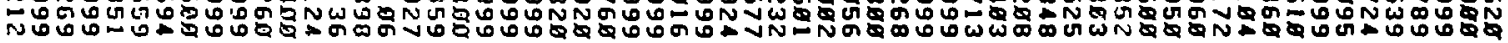

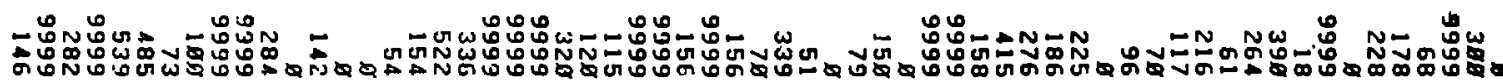

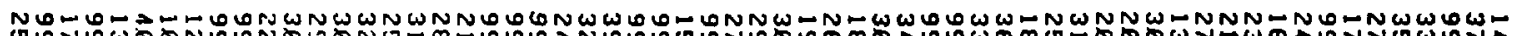

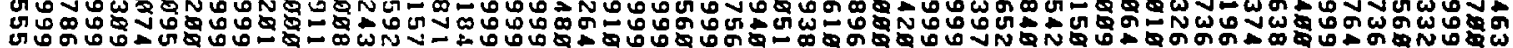

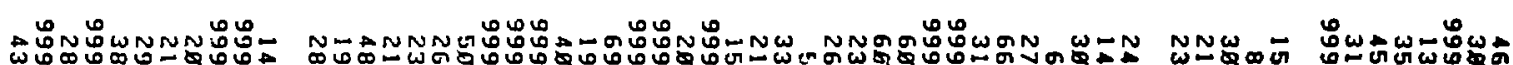

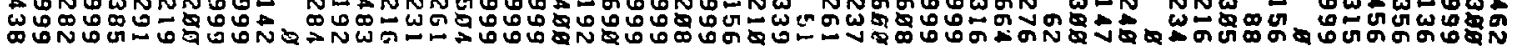

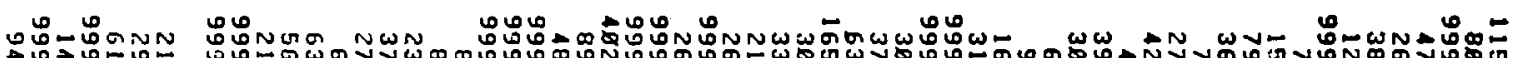

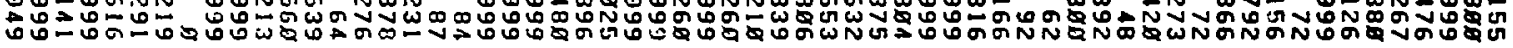

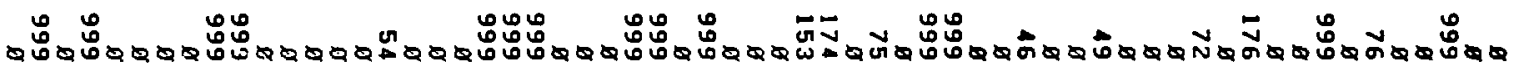
Е

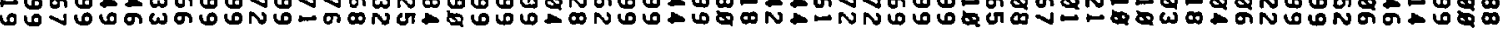
ب

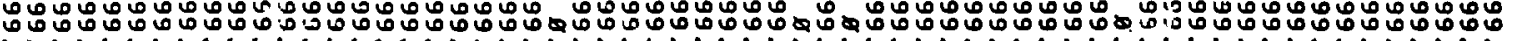

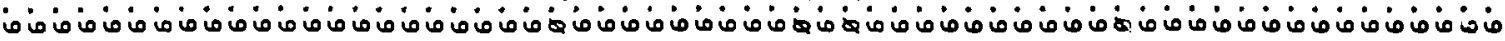

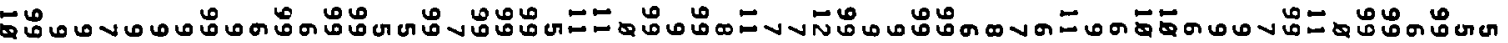

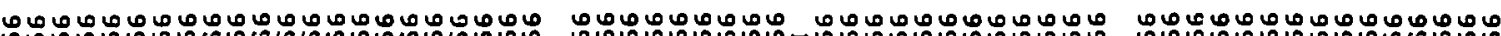
م.000

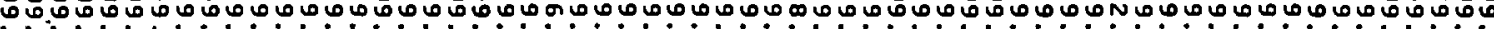
ك

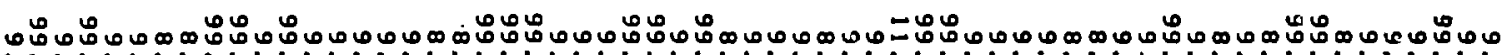

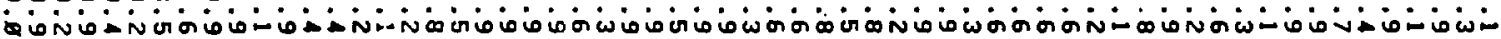

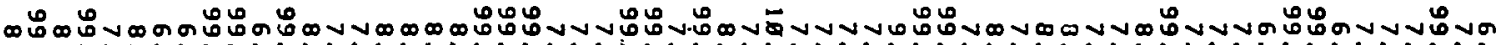
Vi

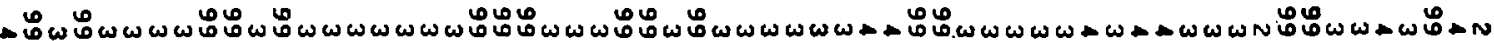

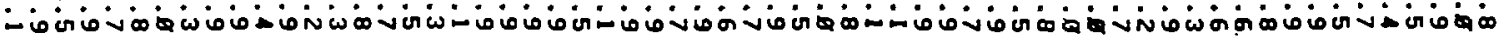

N

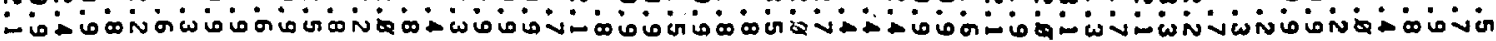




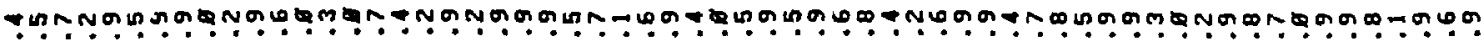

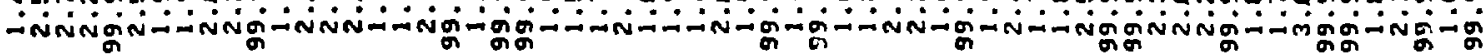

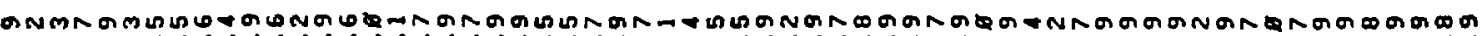

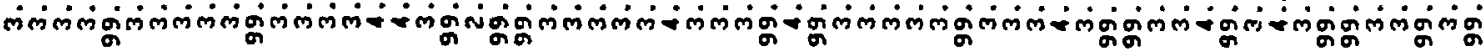

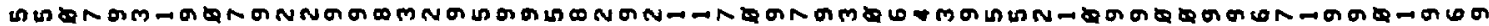

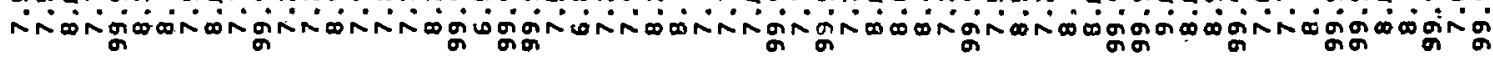

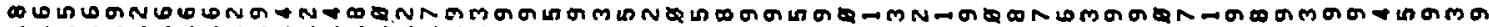

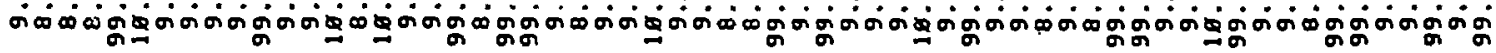

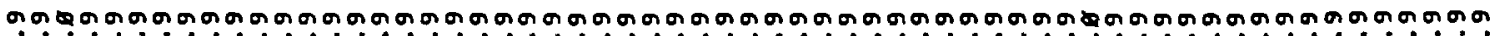

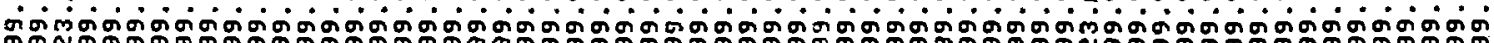

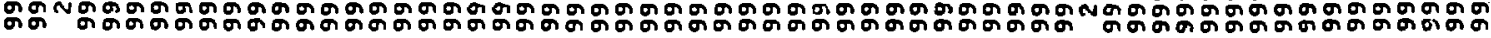

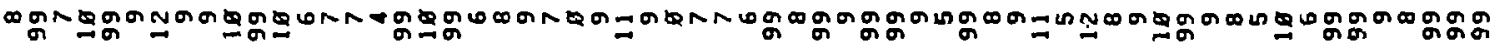

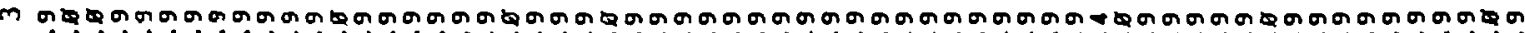

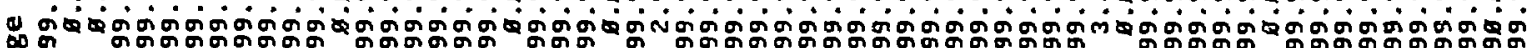

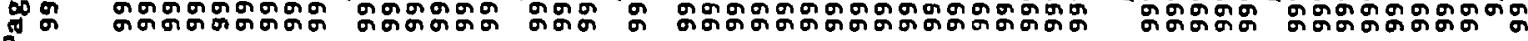
MNNG⿻日NG ใผ

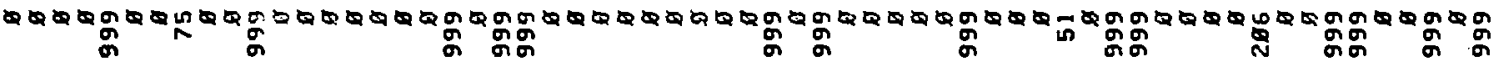

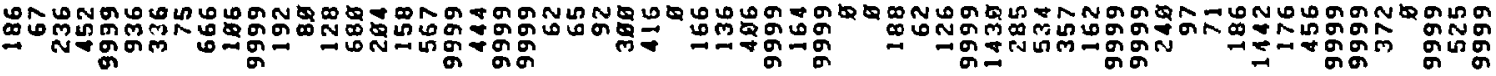

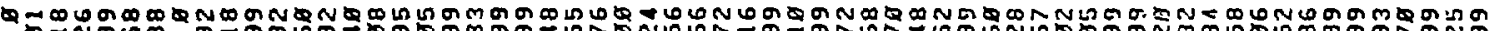

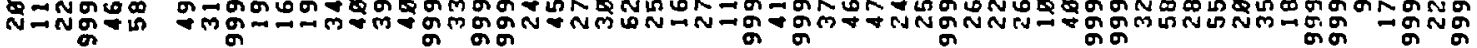

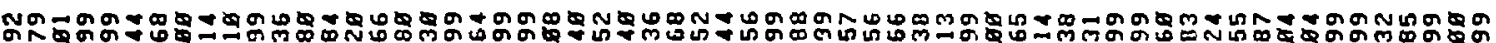

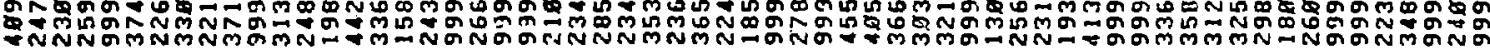

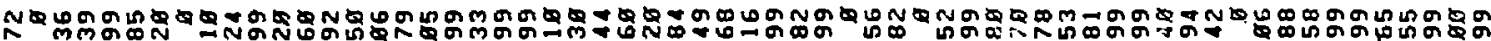

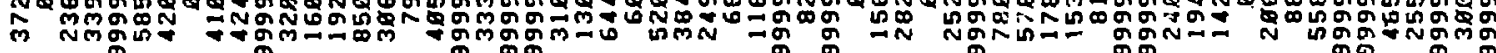

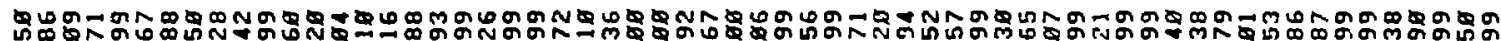

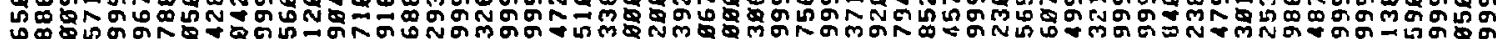

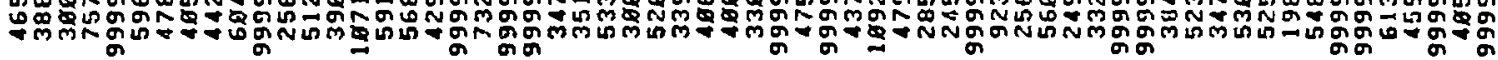

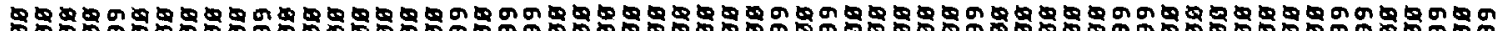

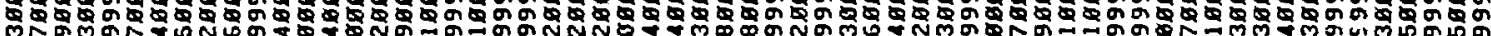

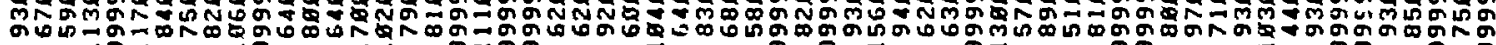

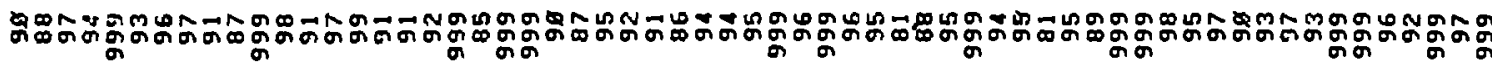

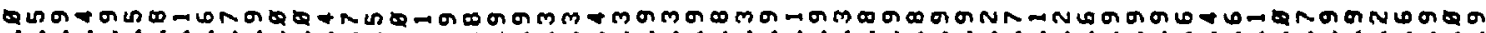
niñ

-

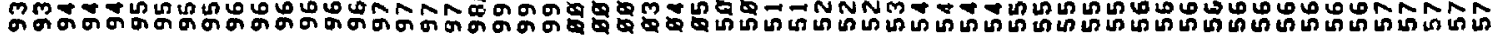

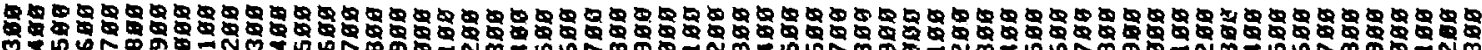

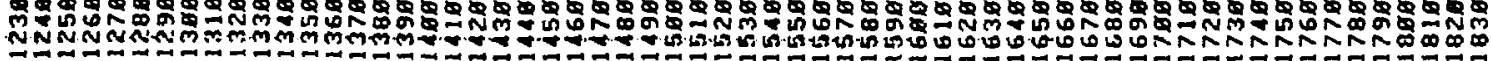




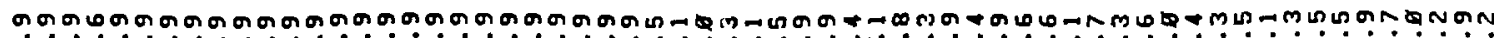

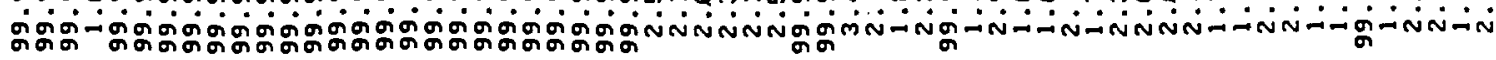

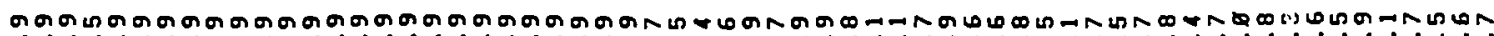

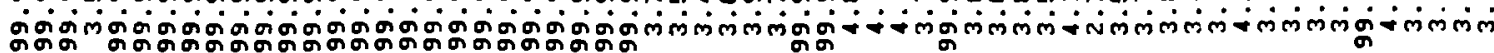

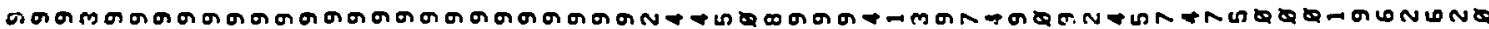

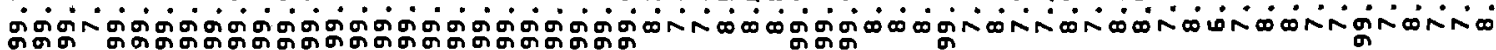

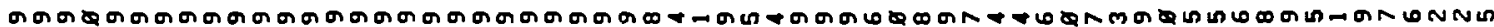

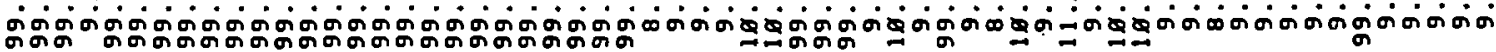

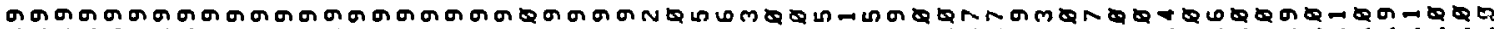

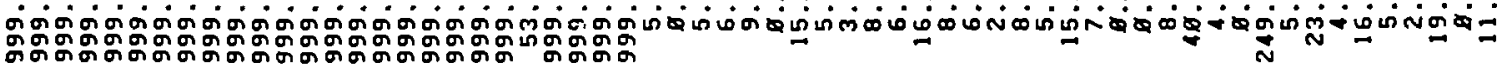

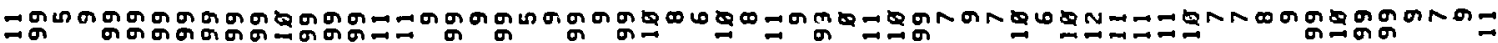

$\stackrel{\$ 0}{0}$

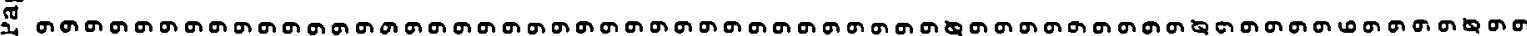

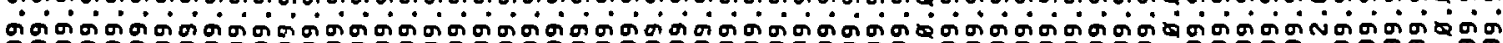

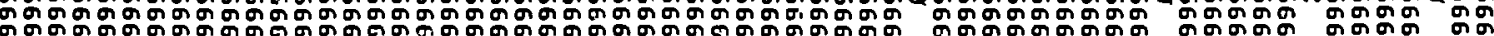

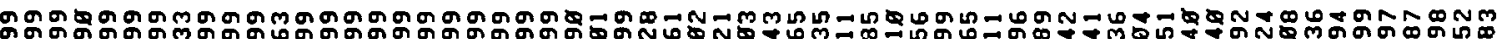
बून बून

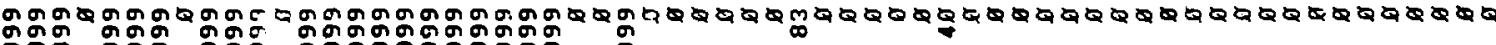

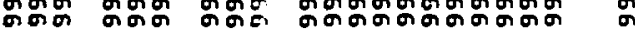

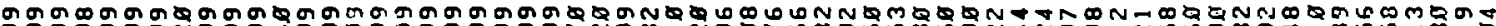

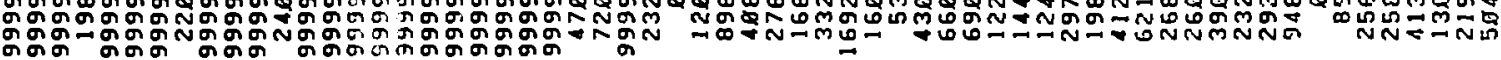

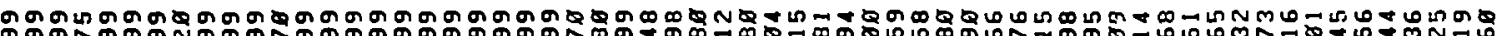

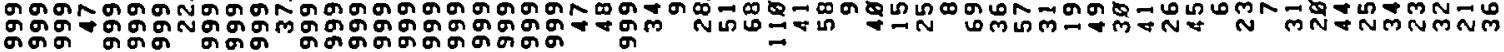

ตбаर

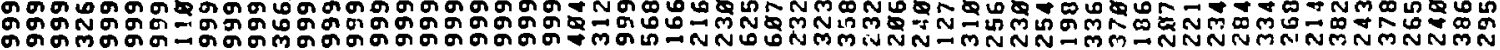

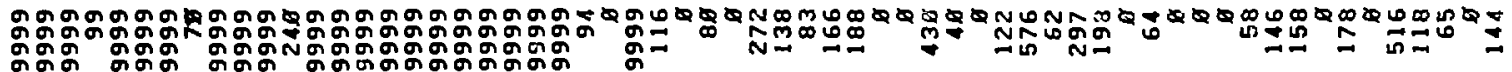

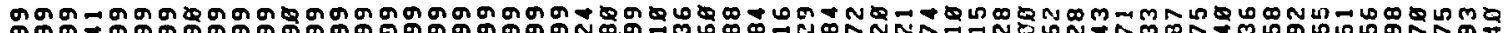

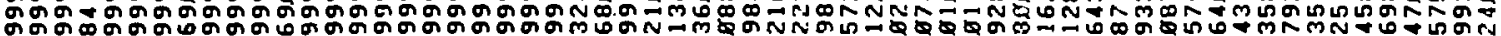

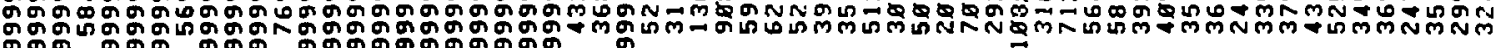

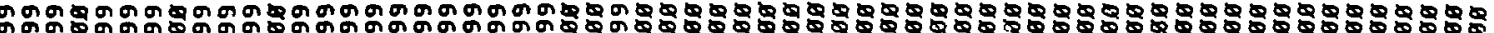
न人รg.

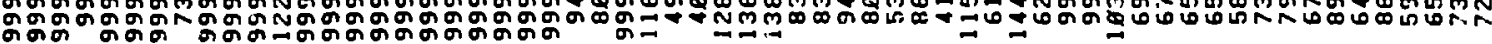

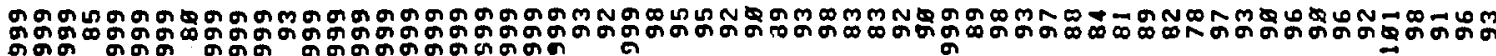

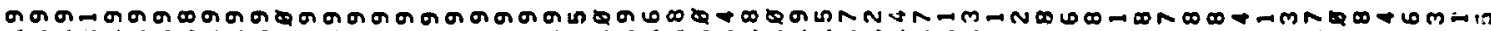

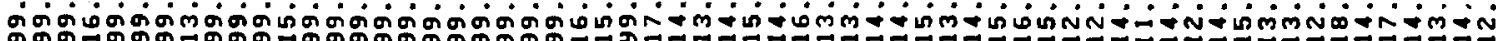

மம்

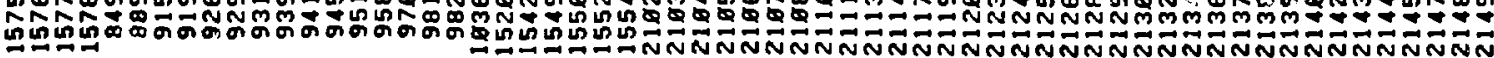


GN" ט.

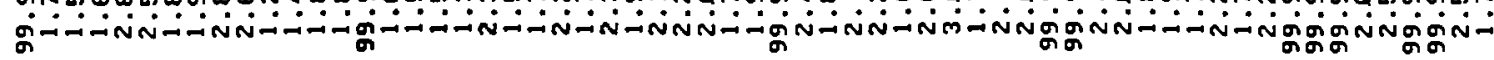

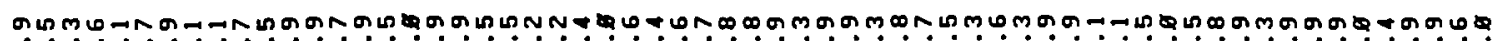

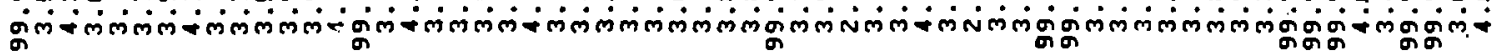

G G gं

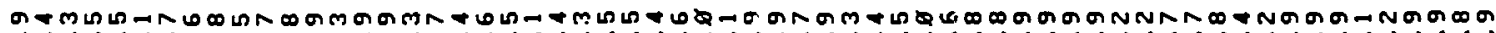

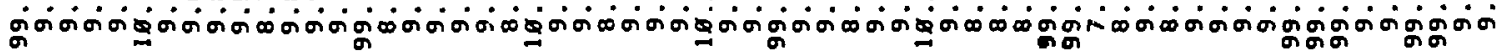

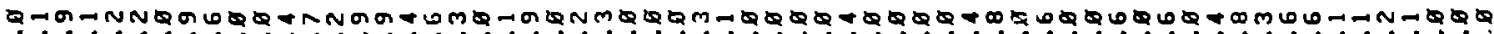
Q ก

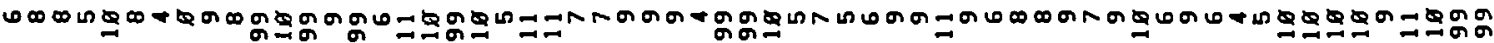

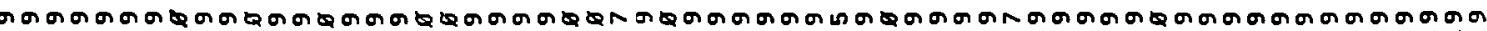

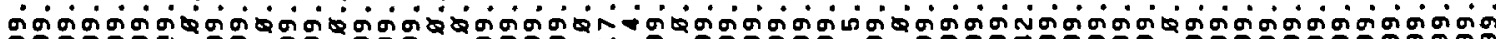

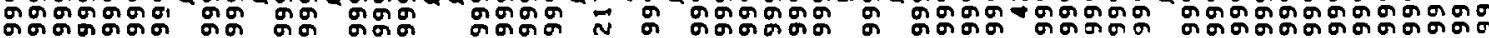

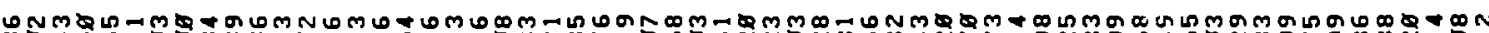

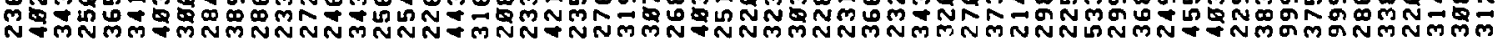

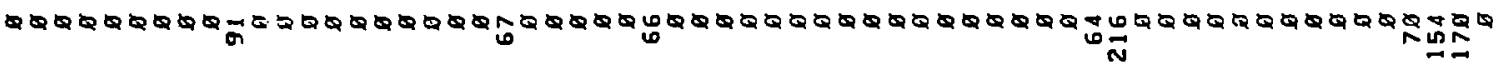

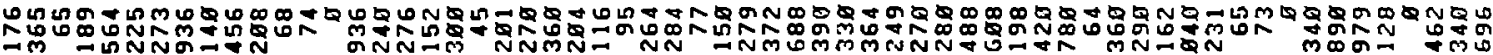

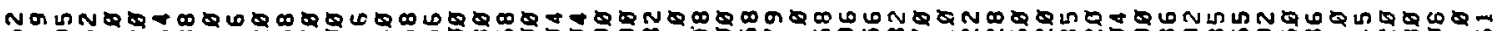

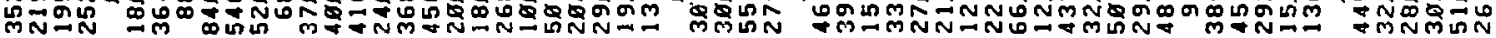

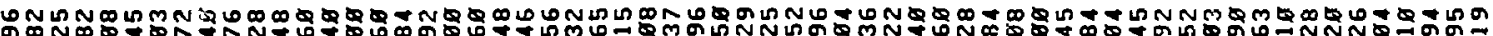
耳ํ. ఐ

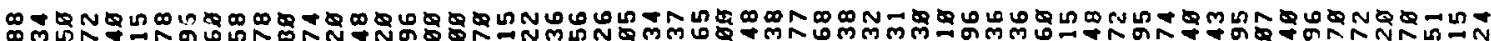

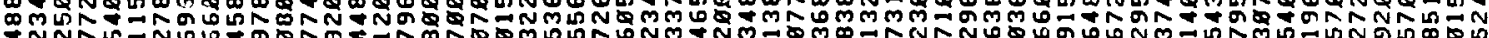

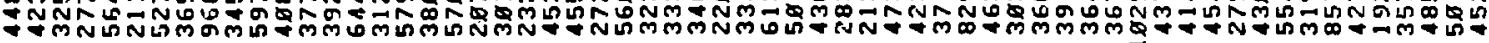

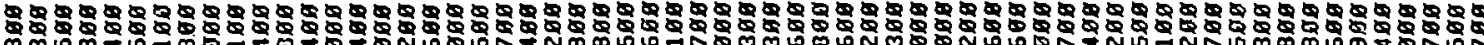

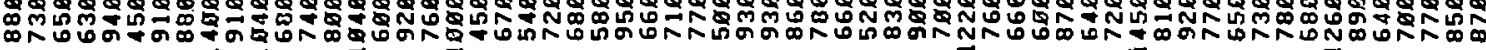

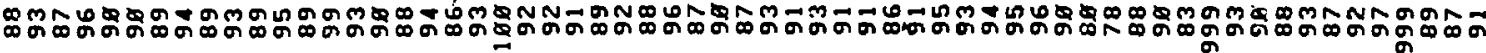

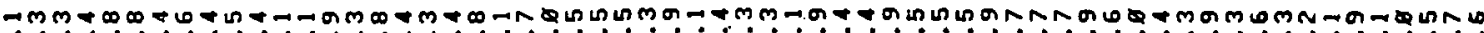

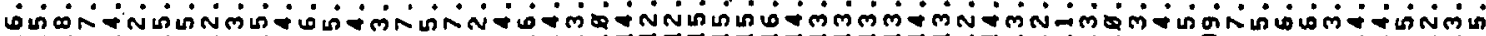

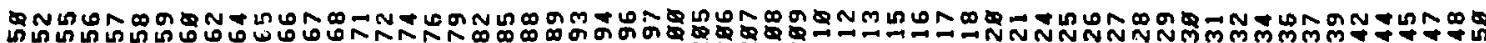

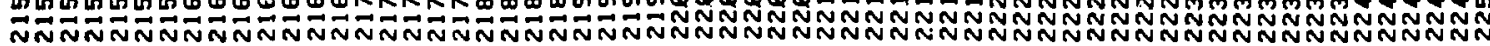




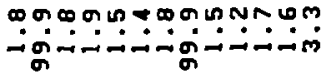

แล

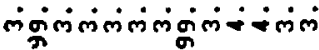

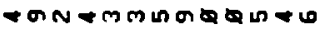

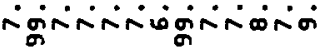

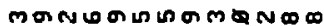

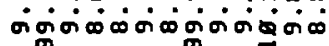

Q Q

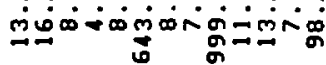

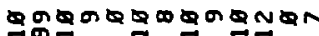
$\infty$

$\pi$

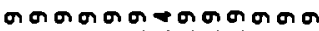

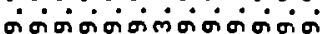

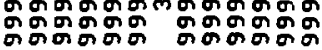

स्तN

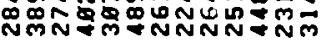

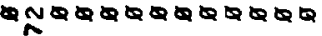

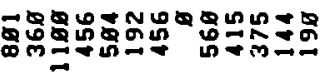

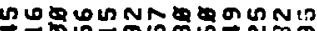

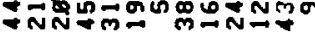

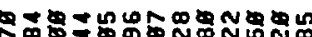

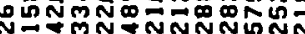

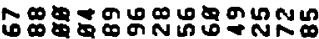
N

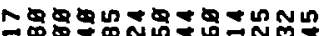

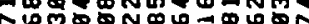
คำ

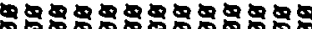

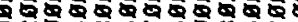

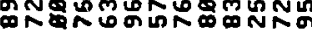
政

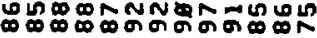

NONGNAーNOMMON

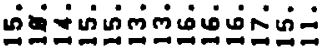

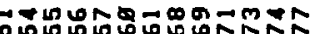
NNNNNNNNNNNNN

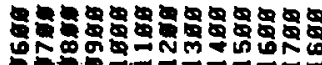

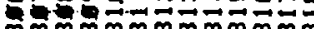

